\title{
Dehydration-rehydration induced structural changes in pristine and composite layered double hydroxides
}

\author{
$\mathrm{PhD}$ Dissertation \\ Valeria Bugris
}

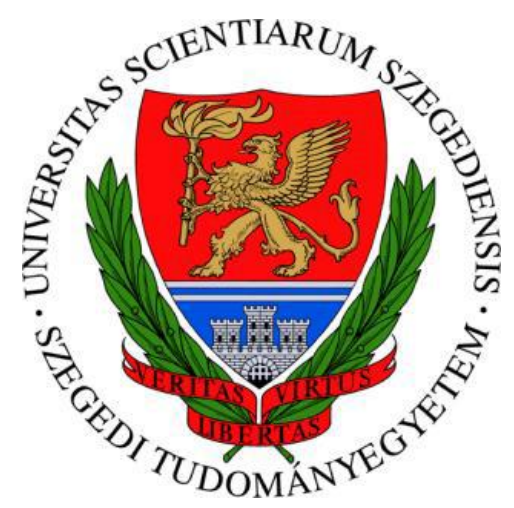

\author{
Supervisors: Dr. Ákos Kukovecz \\ Dr. István Pálinkó
}

Doctoral School of Chemistry

Department of Applied and Environmental Chemistry

Department of Organic Chemistry

Faculty of Science and Informatics | University of Szeged

$$
\begin{gathered}
\text { Szeged } \\
2014
\end{gathered}
$$




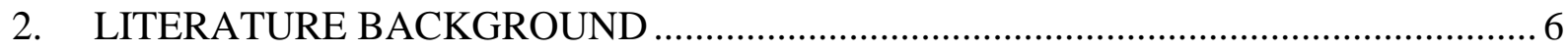

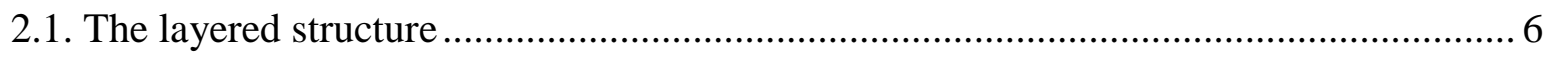

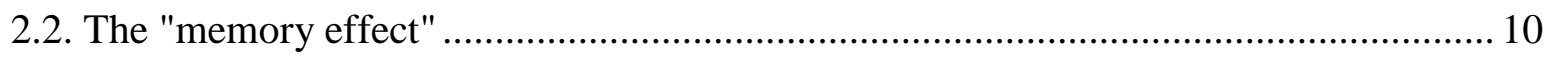

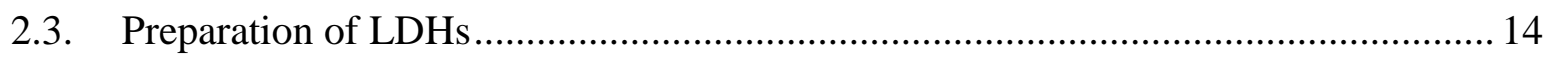

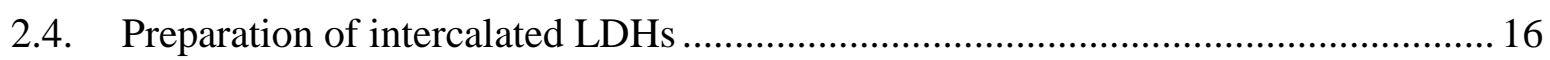

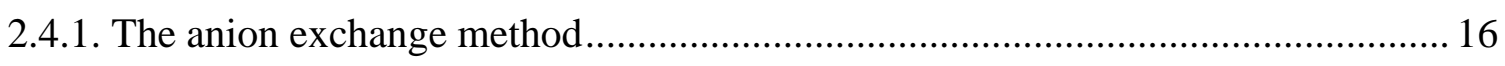

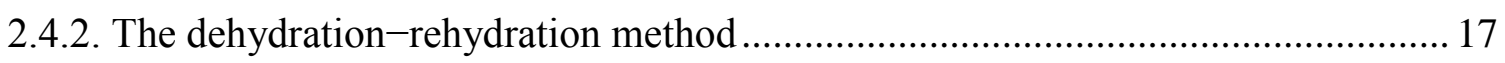

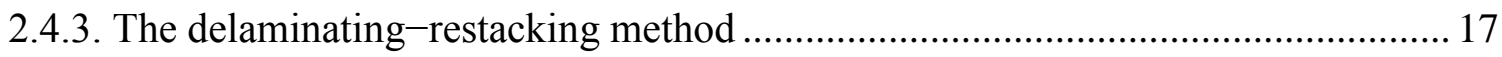

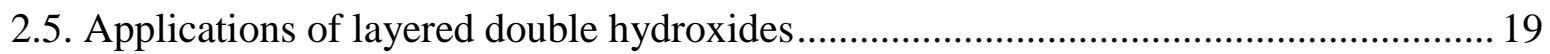

2.5.1. General considerations and miscellaneous applications ....................................... 19

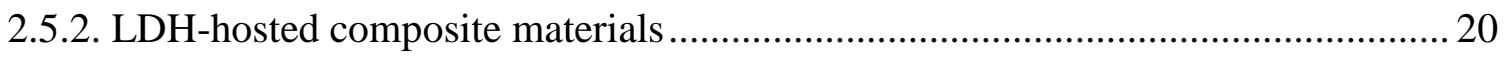

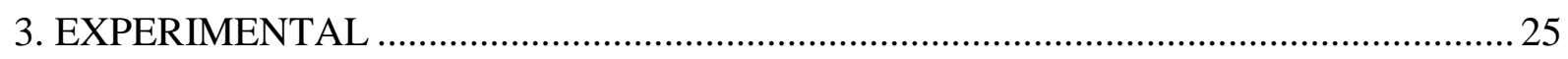

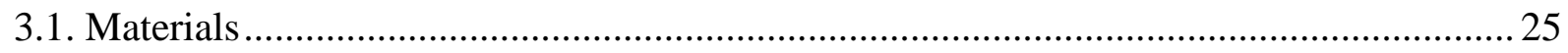

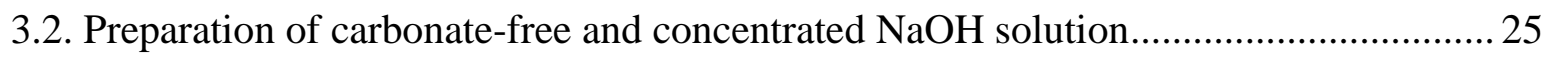

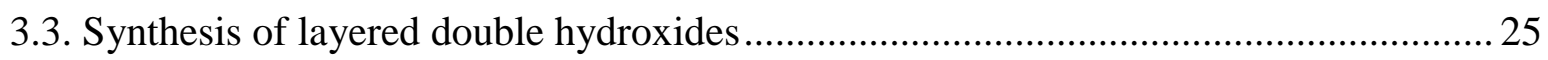

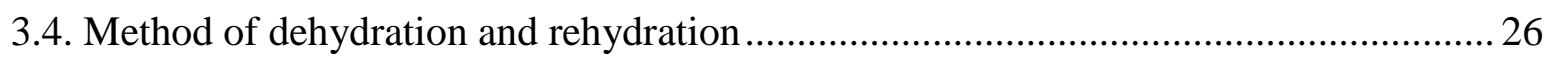

3.5. Synthesis methods of carbon nanotube-layered double hydroxide nanocomposites.... 26

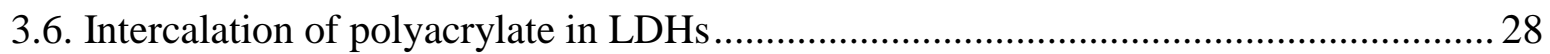

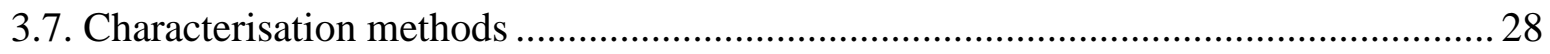

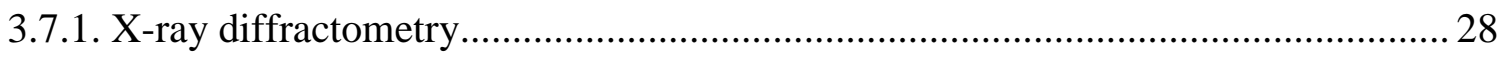

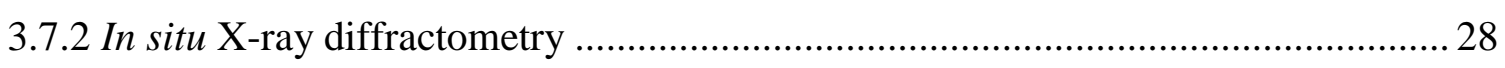

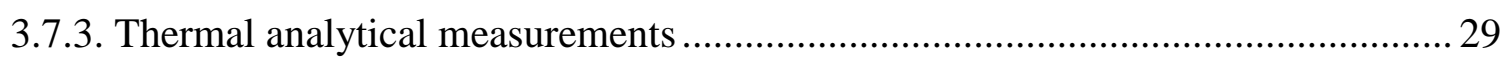

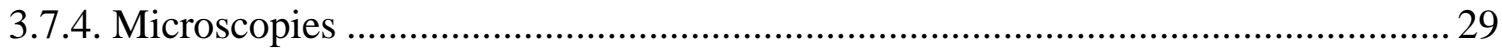

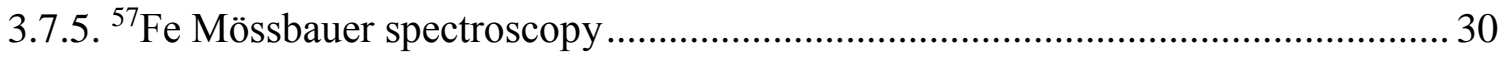

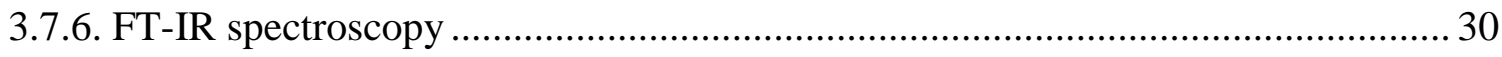

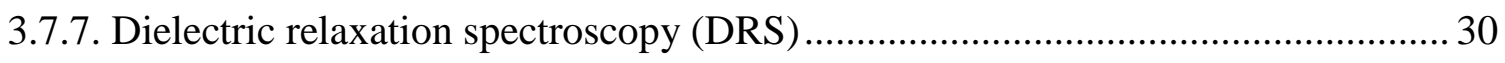

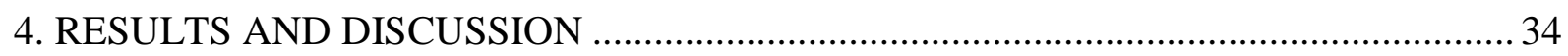

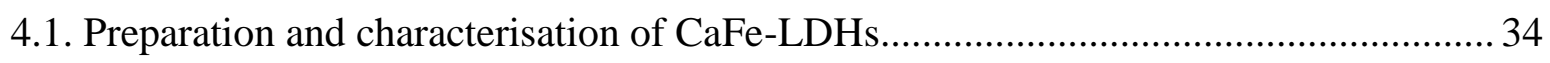

4.2.1. Dehydration and rehydration monitored by dielectric relaxation spectroscopy..... 46

4.1.2. Rehydration followed by in situ XRD measurements..........................................59

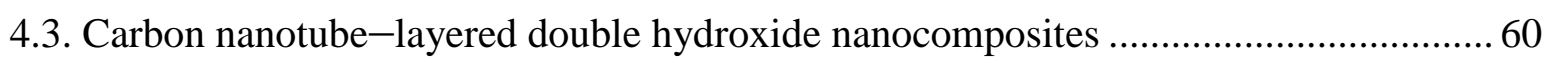


4.4. Polyacrylate-CaFe-layered double hydroxide nanocomposites - structural features .. 65 4.4.1. Dielectric features of the polyacrylate- $\mathrm{Ca}_{3} \mathrm{Fe}$-layered double hydroxide nanocomposites 68

5. SUMMARY .73

References 80 


\section{INTRODUCTION AND THE AIMS OF THE WORK}

Layered double hydroxides (LDHs) comprise materials, which may be called anionic clays. Many of their representatives are of natural origin; however, for practical use, they are usually synthesised. Many synthesis methods are available, and, usually, they are easy and with some effort produce clean, phase-pure materials. The LDHs have structures with high regularity; however, the charge-compensating anions between the layers, containing, in most instances, bi- as well as trivalent cations, can easily be altered through a large variety of methods. Thus, the LDHs are flexible substances, they can be modified and functionalised easily; therefore, they have many potential applications. They may serve as catalysts or catalyst supports, nanoreactors providing confined space for reactants suitably close to each other, transporters of sensitive synthons to the place of the synthesis, containers of medicines, pesticides, fungicides providing their slow release, to mention just a few. No wonder that the scientific literature concerning one or another aspect of LDHs is vast. To give a comprehensive overview of the more than 2,000 pieces of published works, is nearly impossible, or, at least it would clearly overwhelm the dissertation. That is the reason why I am going to set the goals in the immediate followings; and then, in the following chapter, I am going to give a literature account focusing on publications, which are closely related to these goals.

One of the most intriguing properties of an LDH is the so-called "memory effect". On heat treatment the layered structure collapses; however, if it is not too severe - usually below $773 \mathrm{~K}$, but the accurate temperature largely depends on the specific LDH -, it can be recovered in aqueous solution or even in air with large water vapour content. While the dehydration procedure is well studied, information on rehydration is quite limited. Therefore, one of the major goals of the work leading to this dissertation is studying the rehydration process of heat-treated CaFe-LDH with a variety of instrumental methods, and gathering as much information about it as possible.

As it has already been mentioned, the charge-compensating anions between the layers can be altered in a variety of ways. A major method is the dehydration-rehydration procedure, when, the dehydrated LDH and the anionic form of the compound to be intercalated (i.e., introduced in-between the layers) are rehydrated together. During structural reconstruction the anionic guest enters the interlamellar space. Although the method is fairly general, it does not always work. Thus, the other two goals are (i) the synthesis of the carbon nanotube-CaFeLDH nanocomposite, preferably with the dehydration-rehydration method; however, if it 
does not work, then finding a procedure that is operational; and (ii) the synthesis and the many-sided characterisation of a polyacrylate-CaFe-LDH. This latter nanocomposite (the polyacrylate is the guest and the LDH is the host) is unusual, works are more frequent, where the LDHs are embedded in the polymer. 


\section{LITERATURE BACKGROUND}

\subsection{The layered structure}

Layered double hydroxides, due to their anion exchange properties, are (somewhat erroneously) often called anionic clays by the analogy of the cation-exchanging layered silicates [1]. Although LDHs are available as natural minerals [2-4], for chemical applications they are mostly synthesized. The first natural LDH was discovered in Sweden in 1842 [5]. Hydrotalcite is the most frequently occurring and studied representative of LDHs [6]. Its layered structure resembles that of brucite $\left[\mathrm{Mg}(\mathrm{OH})_{2}\right]$, but a part of the $\mathrm{Mg}(\mathrm{II})$ ions is replaced by $\mathrm{Al}(\mathrm{III})$ ions. The metal cations occupy the centres of octahedra, whose vertices are hydroxide ions. These octahedra are connected to each other by edge sharing to form an infinite sheet. These sheets are positively charged, and neutrality is assured by fully or partially hydrated, usually simple inorganic anions of various kinds. Consequently, water molecules are also present among the layers, and occupy various positions.

When the divalent ion is $\mathrm{Ca}(\mathrm{II})$, the structure is somewhat different. Since the calcium ion is significantly larger than the magnesium ion (100 pm vs. $72 \mathrm{pm})$, it is heptacoordinated. The Ca(II)-containing LDHs form a subclass of the hydrotalcite supergroup [4], which is called hydrocalumites [2, 3, 7-9]. In the hydrocalumite-type structure, the layer consists of edge sharing heptacoordinated calcium hydroxide and hexa-coordinated trivalent metal hydroxide polyhedrons.

Figure 1 shows the schematic representation of the layered structure displaying the basic octahedral unit and indicating the meaning of basal spacing (d) and interlamellar space.

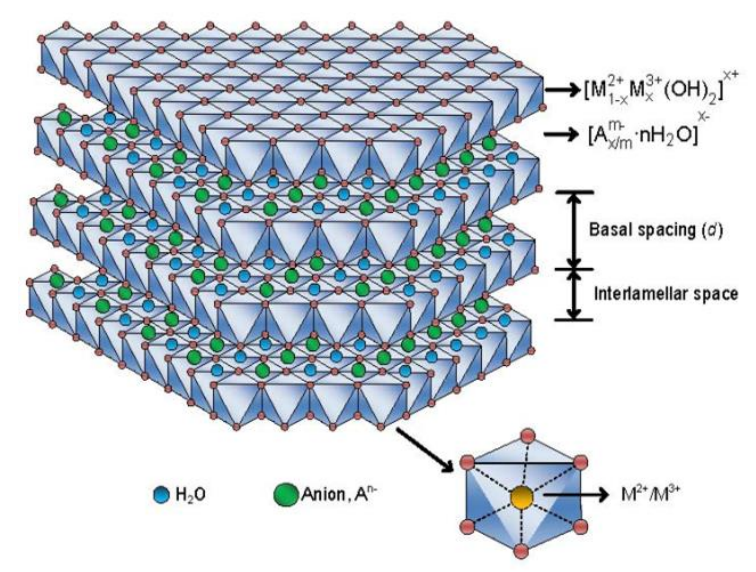

(a)

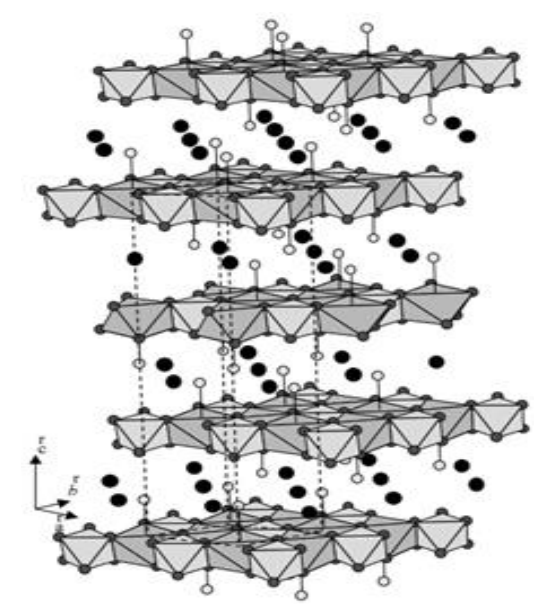

(b)

Figure 1 The schematic structure of a layered double hydroxide (LDH) [10]. (a) The hydrotalcite-type derived from brucite $\mathrm{Mg}(\mathrm{II})(\mathrm{OH})_{6}$ octahedra, $\mathrm{M}(\mathrm{III}) \rightarrow M(I I)$, and the $(b)$ hydrocalumite-type derived from portlandite $\mathrm{Ca}(\mathrm{II})(\mathrm{OH})_{6} \mathrm{H}_{2} \mathrm{O}, \mathrm{M}(\mathrm{III})(\mathrm{OH})_{6}$. 
LDHs can be represented by the general formula: $\left[\mathrm{M}^{\mathrm{II}}{ }_{1-\mathrm{x}} \mathrm{M}^{\mathrm{III}}{ }_{\mathrm{x}}(\mathrm{OH})_{2}\right]\left(\mathrm{A}^{\mathrm{n}-}{ }_{\mathrm{x} / \mathrm{n}}\right] . \mathrm{zH} 2 \mathrm{O}$ (Figure 1), where $\mathrm{M}^{\mathrm{II}}$ and $\mathrm{M}^{\mathrm{III}}$ are di- and trivalent metal cations belonging mainly to the third and fourth periods of the table of elements, like $\mathrm{Mg}, \mathrm{Mn}, \mathrm{Fe}, \mathrm{Co}, \mathrm{Ni}, \mathrm{Cu}, \mathrm{Zn}$ as the divalent and $\mathrm{Al}, \mathrm{Mo}, \mathrm{Fe}, \mathrm{Co}, \mathrm{Cr}, \mathrm{Ga}$ as the trivalent cations [11]. The ionic radii are mostly in the 0.65-0.80 $\AA$ range for divalent cations and $0.62-0.69 \AA$ for trivalent ones [12]. The value of $x$ $\left[\mathrm{x}=\mathrm{M}^{\mathrm{III}} /\left(\mathrm{M}^{\mathrm{II}}+\mathrm{M}^{\mathrm{III}}\right)\right]$ ranges between 0.20 and 0.33 for the $\mathrm{MgAl}$ system, and $\mathrm{A}^{\mathrm{n}-}$ is the interlayer charge-compensating anion, e.g., $\mathrm{CO}_{3}{ }^{2-}, \mathrm{NO}_{3}{ }^{-}$or $\mathrm{Cl}^{-}$[3]. A large number of LDHs with a wide variety of $\mathrm{M}^{\mathrm{II}}-\mathrm{M}^{\mathrm{III}}$ as well as $\mathrm{M}^{\mathrm{I}}-\mathrm{M}^{\mathrm{III}}$ cation pairs with different anions in the interlayer space has been prepared, and their physicochemical properties have been described in the literature [13-16].

In LDHs, the octahedral environment of metallic cations is far from being a regular polyhedron. Along the stacking direction, the octahedra are strongly flattened, lowering the symmetry from $\mathrm{O}_{\mathrm{h}}$ to $\mathrm{D}_{3 \mathrm{~d}}$, as illustrated in Figure 2 for a [ZnAl]-based LDH. The higher is the mean metal ionic radius, the more flattened are the octahedra with a lowering of the layer thickness $h$ and an increase of the distance $a$ between metal ions in a given layer [11].

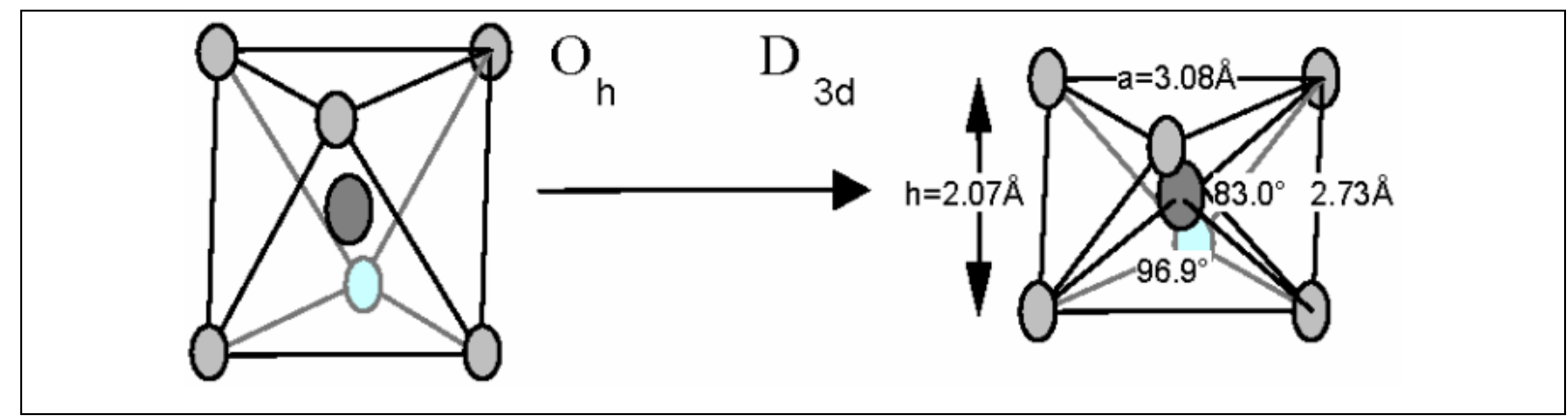

Figure 2 Flattening of the $\mathrm{M}(\mathrm{OH})_{6}$ octahedron in a $\mathrm{ZnAl-LDH} \mathrm{[11].}$

Layered materials are characterised by strong polar covalent bonding along two dimensions and weak bonding along the third dimension, which is also the stacking direction. All sites in the (110) plane of the close packed hydroxide layers can be represented as $\mathbf{A}, \mathbf{B}$ or C related by lattice translations of $(1 / 3,2 / 3,0)$ or $(2 / 3,1 / 3,0)$, and the location of octahedral holes occupied by metal cations can be described analogously as $\mathbf{a}, \mathbf{b}$ or $\mathbf{c}$. Thus, a single layer can be represented as $\mathbf{A b C}$. AbC layers can be stacked in various ways giving rise to a large number of possible polytypes. At the most basic level, these polytypes may be classified in terms of the number of sheets stacked along the $c$ axis of the unit cell. If the opposing $\mathrm{OH}$ groups of adjacent layers lie vertically above one another, a trigonal prismatic arrangement is generated; if the hydroxyls are offset, then the six $\mathrm{OH}$ groups form an octahedral arrangement. Bookin and Drits [17, 18] have systematically derived all of the possible 
polytypes for other stacking sequences. There are three two-layer polytypes, which have hexagonal stacking of the layers $\left(2 \mathrm{H}_{1}, 2 \mathrm{H}_{2}, 2 \mathrm{H}_{3}\right)$, and nine three-layer polytypes. Two of these have rhombohedral symmetry $\left(3 \mathrm{R}_{1}, 3 \mathrm{R}_{2}\right)$ and seven have hexagonal symmetry $\left(3 \mathrm{H}_{1}\right.$ $3 \mathrm{H}_{7}$ ). There is a large number of possible six-layer polytypes, some of which have rhombohedral symmetry (6R) and the remainder hexagonal symmetry $(6 \mathrm{H})$. The identity of the polytype present in a given LDH sample can be determined from the powder XRD pattern. By convention, the indexing of powder patterns for rhombohedral polytypes is based on a triple hexagonal unit cell. The gallery height will depend on the size and orientation of the charge balancing anion. Figure 3 shows the polymorphic forms of naturally occurring LDHs.

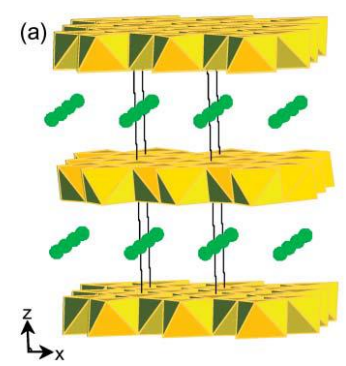

(A)

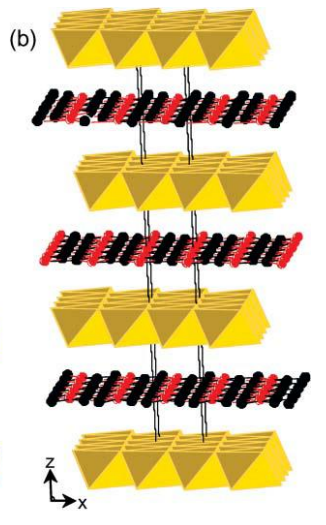

Figure 3 (A) General structure of an LDH showing the polymorphic stacking patterns: (a) hexagonal, (b) rhombohedral [19] and the (B) horizontal view with a layer thickness of $4.8 \AA$ [20].

Hydrotalcite $\left[\mathrm{MgAl}\left(\mathrm{CO}_{3}\right)-\mathrm{LDH}\right]$ and other carbonate-containing $\mathrm{LDHs}$ have $3 \mathrm{R}_{1}$ polytype structure $[1,11]$. Distinguishing between different polytypes is difficult, since the intensities of reflections in the XRD pattern are sensitive to the type of the interlayer anion $[19,21]$. If the radius of one of the cations in the layer becomes too large, the octahedral coordination is lost by opening of one side of the octahedron on the interlamellar domain leading to additional coordination with one interlamellar water molecule. The symmetry around the metal is lowered from $\mathrm{D}_{3 \mathrm{~d}}$ to $\mathrm{C}_{3 \mathrm{v}}$. A behaviour like this is observed in minerals for the hydrocalumite group. For [Ca-Al]-based layers, three different short range distances are observed around calcium: $3 \mathrm{Ca}-\mathrm{OH}$ at $2.375 \AA, 3 \mathrm{Ca}-\mathrm{OH}$ at $2.455 \AA$, and $1 \mathrm{Ca}-\mathrm{OH}_{2}$ at 2.497 $\AA$ [11]. The structure depends on the given arrangement of $\mathrm{Ca}(\mathrm{II})$ and $\mathrm{M}(\mathrm{III})$ ions seven- and six-coordinated, respectively, the seventh apex of the Ca-polyhedron is a water molecule from the interlayer. 
Layered materials are able to intercalate neutral guest molecules and/or inorganic and organic anions. Generally, the interlayer region contains both, i.e., water, as the most frequent neutral molecule and interlayer anions of various kinds. The amount of water in the interlayer region is determined by factors such as the nature of the interlayer anions, the vapour pressure of water and the temperature. The water molecules are connected both to the metal hydroxide layers and the interlayer anions through hydrogen bonding [22]. The interlayers are substantially disordered and hydrogen bonds are in a continuous state of flux, thus, the precise nature of the interlayer is rather complex [19]. The bonding between octahedral layers, interlayer water molecules and anions involves a combination of hydrogen bonding and electrostatic effects. Hydroxyl groups, particularly those bonded to trivalent cations are strongly polarised and interact with the interlayer anions. Every anion has to satisfy excess positive charges on both of the sandwiching octahedral layers, which are electrically balanced by two neighbouring interlayers. It has been suggested that charge compensation in LDHs has many of the characteristics of resonance effects [23].

During the formation of the lamellar structure, or by post-synthetic modification, large variety of anionic compounds may be introduced between the layers. In naturally occurring LDHs, the most common anion found is carbonate. In practice, however, there is no significant restriction to the nature of the charge balancing anion that can occupy the interlayer region; e.g., halides and oxo anions [24, 25], silicates [26], polyoxometalate anions [27] complex anions [28] as well as organic anions, may be incorporated. The identities and ratios of the di- and trivalent cations and the interlayer anion may also be varied over a wide range, giving rise to a large class of isostructural materials. It is more difficult to characterise the structure of interlamellar fields than the main layers, but even for this purpose X-ray diffraction (XRD) is the major experimental tool.

Besides XRD, large variety of instrumental methods is available for characterising LDHs. Some of them are of general use:

- transmission electron microscopy (TEM, suitable for verifying the existence of the layered structure and directly measuring layer thickness),

- scanning electron microscopy (SEM, used for studying the morphology of the material),

- energy-dispersive X-ray analysis (EDX, allowing the qualitative and semiquantitative analysis of the constituents),

- SEM-EDX measurements (for obtaining an elemental map), 
- thermal methods (TG, DTG, for investigating the dehydration of the LDH and the decomposition of the interlayer anions),

- vibrational spectroscopies (IR, Raman, providing detailed structural information about the $\mathrm{OH}$ groups of the host and the guest molecules and anions),

- dielectric relaxation spectroscopy [29] (DRS, applicable for determining the positions of water molecules in/on LDHs).

Others, like Mössbauer and X-ray absorption spectroscopies [30, 31] are element (ion) specific. Although they can give crucial information on the local environment, they are not of general use.

As it has been mentioned, powder XRD is the most frequently employed technique for characterising LDHs. Diffractograms are normally obtained using randomly oriented powdered samples, although in certain cases oriented samples have also been studied. A typical diffractogram obtained for an LDH consists of sharp basal $(00 l)$ reflections at low values of $2 \Theta$ corresponding to successive orders of the interlayer spacing. In addition, relatively weak non-basal reflections at higher values of $2 \Theta$ are also present. In certain cases, the non-basal reflections are quite broad, which may be attributed to turbostratic disordering of the hydroxide layers.

\subsection{The "memory effect"}

When an LDH is calcined, it progressively loses physisorbed water molecules, interlamellar water molecules (and possibly interlamellar anions), and finally, water, corresponding to the dehydroxylation of the layers, leading to the collapse of the layered structure. Temperature ranges at which these phenomena occur depend on the chemical composition of the original LDH. Nevertheless, around $773 \mathrm{~K}$, a mixed oxide is generally formed [11, 32, 33]. For some hybrid LDHs, this step takes place before the pyrolysis of organic species, giving a hybrid layered compound with amorphous inorganic oxide layers. Depending on the nature of the interlamellar species, they can either remain intact (phosphates or oxometalates), or be removed at a certain, but generally higher temperature (sulphate or chloride), or be lost at a relatively low temperature during the dehydroxylation step (carbonates). After dehydroxylation, quasi-amorphous mixed oxides are obtained, which crystallise progressively at higher temperatures, generally, as a $\mathrm{M}^{\mathrm{II}} \mathrm{M}^{\mathrm{III}}{ }_{2} \mathrm{O}_{4}$ spinel-like phase and the divalent metal oxide. The ill-organised mixed oxides usually display three broad diffraction maxima corresponding to the strongest lines of the would-be spinel-like phase; therefore, they are called pre-spinel oxides. In general, these mixed oxides have relatively 
high specific surface areas (up to $150 \mathrm{~m}^{2} \mathrm{~g}^{-1}$ ) compared to those of the as-prepared LDHs $(\sim 15$ $\left.\mathrm{m}^{2} \mathrm{~g}^{-1}\right)$.

It is intriguing that the calcined $\mathrm{LDH}$, when the temperature of heat treatment is not too high (about $773 \mathrm{~K}$, but the exact temperature depends on the specific LDH), is able to regenerate the layered structure, when it is exposed to water (and anions) [34]. If the temperature is higher than $773 \mathrm{~K}$, the loss of the layered structure becomes irreversible.

In the literature, only a few studies are focused at the kinetic description of the processes taking place during the thermal decomposition of LDHs [35, 36]. Valente et al. investigated the thermal decomposition mechanisms, and the kinetics of the transformation from $\mathrm{LDH}$ to $\mathrm{Mg}(\mathrm{Al}) \mathrm{O}$ mixed oxide [37]. In general, four major steps were identified. They are as follows [37, 38]:

- continuous dehydration and dehydroxylation of the layers, between room temperature and $523 \mathrm{~K}$,

- decomposition of the interlayer anions between 523 and $623 \mathrm{~K}$,

- shrinkage and then collapse of the layered structure, between 623 and $823 \mathrm{~K}$,

- crystallisation of new phases.

The dependence of activation energies $\left(E_{a}\right)$ of the four steps on the degree of conversion $(\alpha)$ for $\mathrm{MgAl}-\mathrm{CO}_{3}-\mathrm{LDH}$ is displayed in Figure 4.

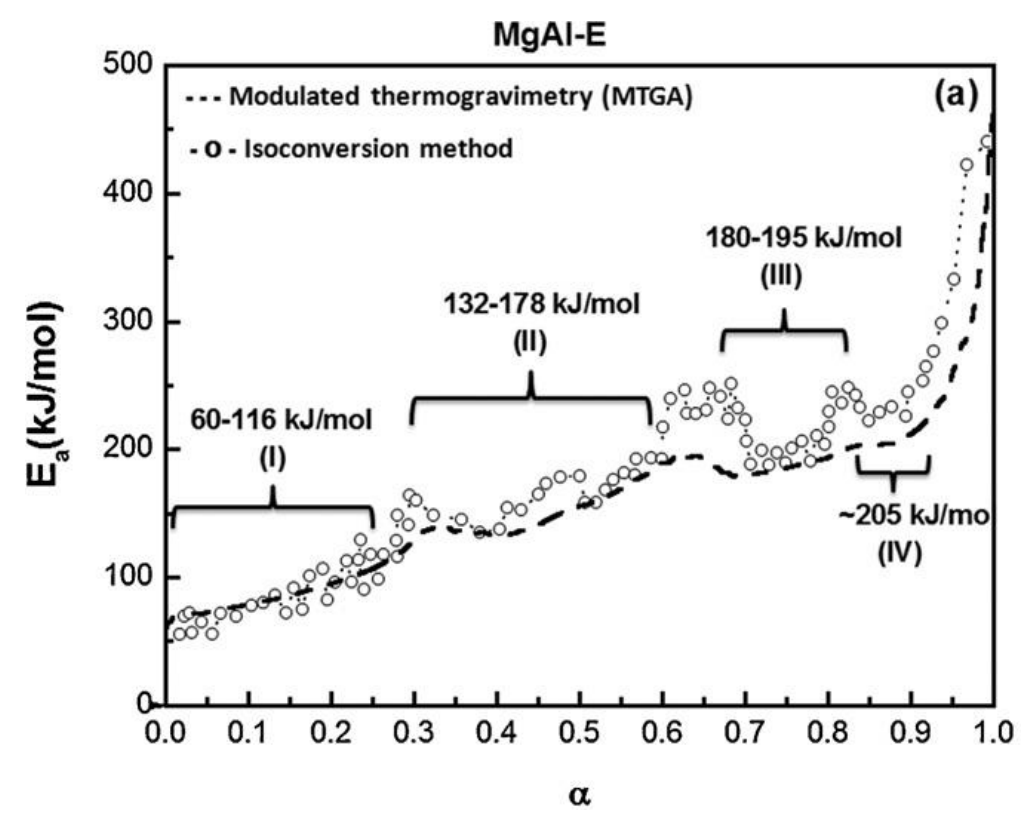

Figure 4 Dependence of activation energies $\left(E_{a}\right)$ on the degree of conversion $(\alpha)$ of dehydration by modulated thermogravimetry and the isoconversional method for MgAl-LDH (MgAlE) [37]. 
Rehydration was not investigated, but was assumed to occur similarly, except that the steps were reversed. During this process, water was absorbed to reform the hydroxyde layers, and anions and water were incorporated into the interlayer galleries. The anions incorporated do not necessarily need to be the ones that were in the original LDH material, and thus, this can be considered as a new and alternative method of intercalation [39, 40]. Surfactants [41], amino acids, peptides [42], and even non-ionised guest pentoses [40] have been incorporated through the rehydration process.

The conversion of the mixed metal oxides into LDHs has been referred to as regeneration, reconstruction, restoration, rehydration or the "calcination-rehydration process", "structural memory effect" or simply "memory effect". This method is usually employed when large guests are intercalated, and provides an effective synthetic route for inserting inorganic and organic anions into LDHs. It also avoids the competitive intercalation of inorganic anions originating from the metal salts.

In 1980 Miyata [43] was the first to describe the reconstruction of the original LDH structure by hydration of the calcined $\mathrm{LDH}$. He reported that hydrotalcite $\left[\mathrm{MgAl}\left(\mathrm{CO}_{3}\right)-\mathrm{LDH}\right]$ transformed into a mixed magnesium aluminium oxide after heat treatment, which was rehydrated and combined with anions to reform an LDH in the presence of water and anion. It should be noted that both the calcination temperature and the chemical composition of the LDH sheets had significant influence on the reconstruction process.

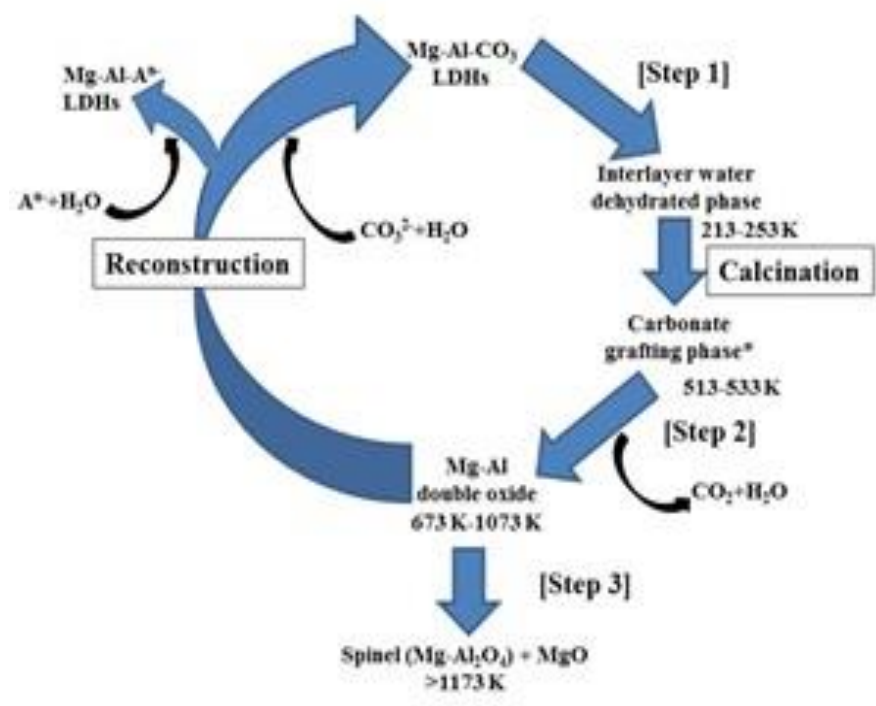

Figure 5 Decomposition of $\mathrm{MgAl}-\mathrm{CO}_{3}-\mathrm{LDH}$ by calcination and its reconstruction in aqueous solution [44].

Marchi et al. [45] have studied the reconstruction from $\mathrm{Cu} / \mathrm{Co} / \mathrm{Zn} / \mathrm{Al}$ mixed oxides upon impregnation with aqueous alkaline solutions. (Quaternary $\mathrm{Cu} / \mathrm{Co} / \mathrm{Zn} / \mathrm{Al}$ mixed oxide was 
employed for obtaining mixtures of methanol and linear higher alcohols from synthesis gas, and it was impregnated with $c a .1 \mathrm{wt}$. \% of potassium.) Not surprisingly, it was found that the "memory effect" was reduced on increasing the calcination temperature of the parent LDH. Increased calcination temperature induced the solid-state diffusion of divalent cations into tetrahedral positions, which resulted in the progressive formation of stable spinels. After calcination of a $\mathrm{Cu} / \mathrm{Co} / \mathrm{Zn} / \mathrm{Al} \mathrm{LDH}$ at $873 \mathrm{~K}$, for instance, all the divalent cations occupied tetrahedral sites and the "memory effect" was lost [45].

Cu-Co-Zn-AI LDH

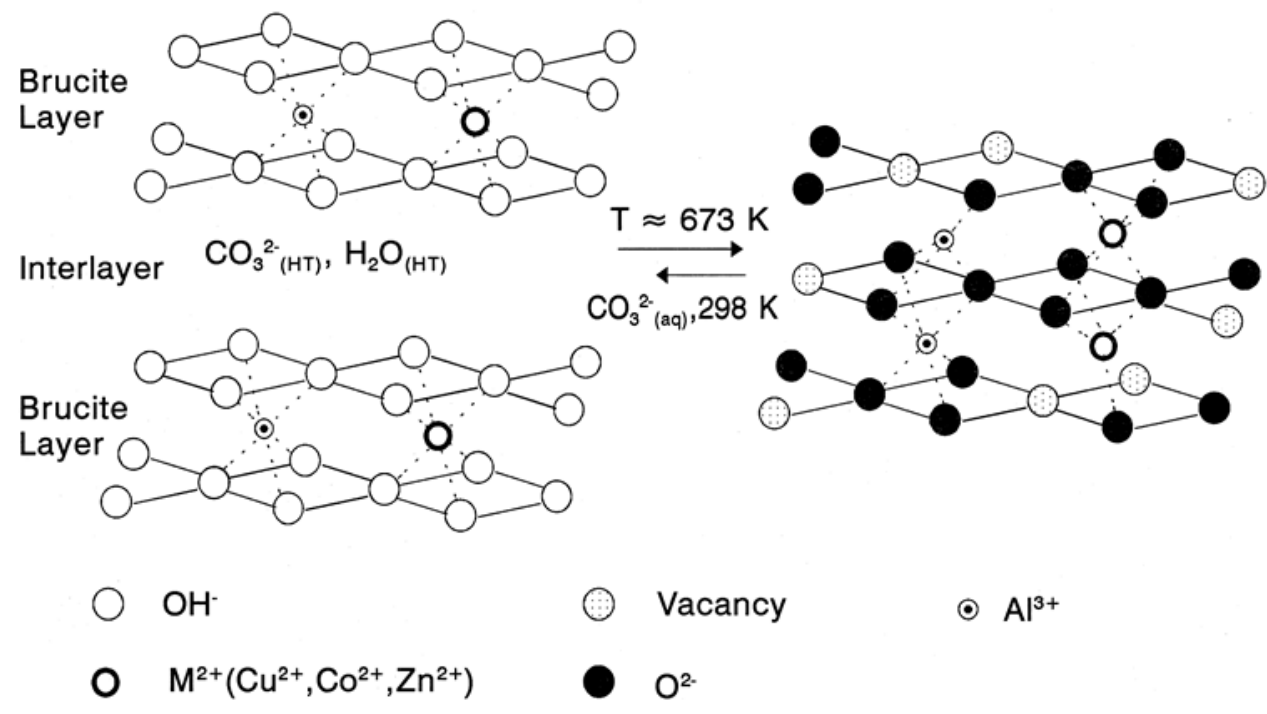

Figure 6 "Memory effect" of calcined CuCoZnAl-LDH. Scheme of the decomposition/reconstruction of the parent $\mathrm{LDH}$ [45].

For MgAl-LDHs [34], powder XRD and ${ }^{27} \mathrm{Al}$ NMR measurements revealed that calcination at increasing temperatures led to the migration of $\mathrm{Al}^{3+}$ ions to tetrahedral sites, while the crystalline structure was progressively destroyed. Upon rehydration with water vapour, the layered LDH structure was recovered to varying extents, depending on the previous calcination temperature, as well as on the rehydration time at $298 \mathrm{~K}$. Reconstruction was complete after rehydration for $24 \mathrm{~h}$, when the sample was calcined at or below $823 \mathrm{~K}$. Equilibration for 3 days was required to reconstruct the samples previously calcined at 1023 K. Partial reconstruction was only possible after calcination at $1273 \mathrm{~K} .{ }^{27} \mathrm{Al}$ MAS NMR indicated that tetrahedral $\mathrm{Al}$ and spinel phases still existed in the solids, even when powder XRD indicated the complete recovery of the LDH structure.

Pfeiffer et al. [46-48] published a thorough study on the rehydration process of MgAlLDH via taking the adsorption-desorption isotherms and following the steps by thermogravimetric, ${ }^{27} \mathrm{Al}$ MAS NMR and SAXS (small-angle X-ray diffraction) 
measurements. The activation enthalpies $(\Delta \mathrm{H})$ for the steps of the reconstruction process were determined at various relative humidities. The absorption process was found to be more dependent on the temperature, when the relative humidity was lower [46]. The rehydration processes of the samples with varying $\mathrm{Mg} / \mathrm{Al}$ ratios between 2 and 4 were analysed under isothermal conditions using various humidities and temperatures [47]. Three different processes were identified during the rehydration procedure: (i) $\mathrm{H}_{2} \mathrm{O}$ adsorption, (ii) $\mathrm{H}_{2} \mathrm{O}$ absorption and (iii) $\mathrm{H}_{2} \mathrm{O}$ desorption. It was experienced that at $\mathrm{Mg} / \mathrm{Al}$ molar ratios of 2.5 and 3.0, the LDH samples absorbed water faster than the other samples, independently of the temperature and relative humidity. These results were explained by the structural features of the LDH samples: when the molar ratio was 2, the cations were ordered in a honeycomb-like structure, and the degree of ordering was inversely proportional to the $\mathrm{Mg} / \mathrm{Al}$ ratio, even though the distribution remained non-random. The activation enthalpies $(\Delta \mathrm{H})$ were also obtained as the function of the relative humidity. These results proved that $\mathrm{H}_{2} \mathrm{O}$ absorption was more dependent on the temperature, when the relative humidity was low in general, and for the samples with 2.5 and $3 \mathrm{Mg}$ to $\mathrm{Al}$ ratios, in particular [47].

\subsection{Preparation of LDHs}

The first method for preparing synthetic LDHs is based on the controlled precipitation of aqueous solutions containing the metallic cations, and began with the early work of Feitknecht [49]. Since then, several alternative techniques have been developed. They have been reviewed several times $[11,32,50]$.

The method of co-precipitation is the most commonly used preparative technique for LDHs. It has been used extensively for the one-pot direct synthesis of LDHs containing a variety of layer cations and interlayer anions [51]. It is also amenable to scale up when large quantities of material were needed. In it, an aqueous solution of $\mathrm{M}^{2+}$ (or a mixture of $\mathrm{M}^{2+}$ ions) and $\mathrm{M}^{3+}$ (or a mixture of $\mathrm{M}^{3+}$ ions) containing salts is precipitated with the help of an aqueous basic solution. The base was originally (and still most often) aqueous $\mathrm{NaOH}$ or $\mathrm{KOH}$; however, lately, the weak base urea is frequently used as replacement of the strong bases [52]. Co-precipitation can be performed under conditions of high super saturation or at low saturation. The first ensures simultaneous precipitation of two or more cations [32]. Following co-precipitation, a thermal treatment process is often performed in order to increase yields and/or the crystallinity of amorphous or microcrystalline materials. Low saturation coprecipitation corresponds to the slow addition of mixed solutions of divalent and trivalent metal salts in the chosen ratio into a reactor and then, an aqueous solution of the base is added 
at a rate to maintain the $\mathrm{pH}$ at a selected value [53]. The advantages of this method are the high precision and the high crystallinity of the material obtained. The experimental setup used for the preparation of LDHs by the co-precipitation method is seen in Figure 7.

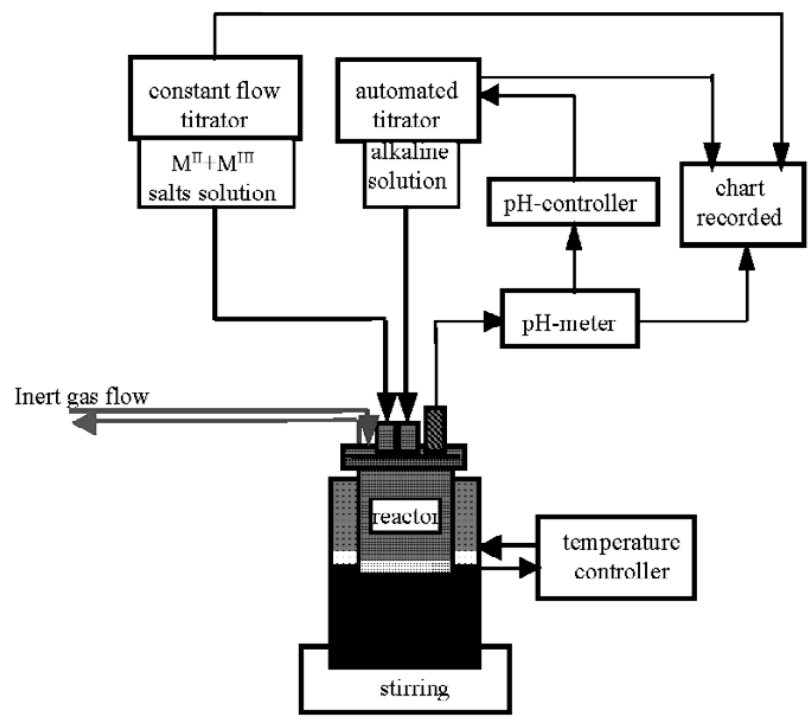

Figure 7. The experimental setup for the preparation of LDHs by the co-precipitation method [11].

Formation of crystallites involves two stages: nucleation and aging. The method of separate nucleation and aging steps (SNAS) is excellent to control size distribution [54]. The key features of this method are a very rapid mixing and nucleation process in a colloid mill followed by separate aging process. The design of the colloid mill is schematically illustrated in Figure 8. The disadvantage of this method is the high cost of the required equipment.

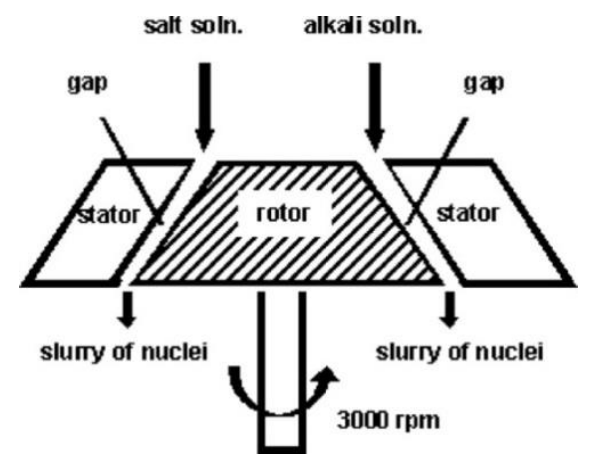

Figure 8 Schematic illustration of a colloid mill [1].

Non-conventional techniques such as microwaves and ultrasound have been employed in chemical reactions because of their unique features which make them different from conventional energy sources [1]. The preparation of LDHs using microwave sources has been found to be rapid and convenient [55]. Similarly, ultrasound has also been used in the synthesis of LDHs. The LDHs synthesized under ultrasonic conditions showed larger 
crystallite size and larger adsorption capacity of humic substances than those synthesized without ultrasonic treatment [56].

Salts and oxides as metal ion sources are also used for the preparation of LDHs [11], and LDHs can also be prepared by mechanochemical means. This way, e.g., MgAl-LDH has been prepared recently [57].

\subsection{Preparation of intercalated LDHs}

Intercalation reactions are particularly important as they can be utilised to dramatically change the chemical, electronic, optical, and magnetic properties of the host LDH. Literature concerning the intercalation chemistry of LDH hosts is very extensive.

To achieve the incorporation of materials within the interlayer gallery of LDHs several strategies may be considered. To the preparation of intercalated LDHs there are some general approaches, like anion exchange, direct synthesis by co-precipitation, the dehydration-rehydration method, delamination followed by restacking, etc. [11, 21, 58, 59]. Upon applying any of these methods aerial $\mathrm{CO}_{2}$ must be excluded since the resulting carbonate anion is readily incorporated and tenaciously held in the interlayer. Consequently, decarbonated and deionised water is to be used and exposure of the reacting material to the atmosphere is kept to a minimum.

The anion-exchange and the dehydration-rehydration methods are the most frequently used techniques for intercalation. The delamination-restacking method is relatively scarcely applied; nevertheless, its discussion will also be included, since we had to use it, when the dehydration-rehydration technique failed.

Unfortunately, none of the intercalation methods are of general use and the success of outcome cannot be predicted in advance. Trial and error is the only way of finding the suitable intercalation method.

\subsubsection{The anion exchange method}

The anion-exchange properties of LDHs containing simple inorganic anions are well documented [43]. The ease of exchange of monovalent anions is in the order $\mathrm{OH}^{-}>\mathrm{F}^{-}>\mathrm{Cl}^{-}>\mathrm{Br}^{-}>\mathrm{NO}_{3}^{-}>\mathrm{I}^{-}$. Divalent anions are more firmly held between the layers than the monovalent ones; actually, the presence of the carbonate ion severely hinders the introduction of any other anions into the interlayer space [21]. LDHs intercalated with nitrate ions are, therefore, the most suitable precursors for anion exchange syntheses, due to the relative ease with which the nitrate anions can be displaced from the interlayer. 
However, the incorporation of more complex inorganic anions is not an easy exercise. In general, it is carried out by dispersing the precursor LDH in aqueous solution containing excess of the organic anion. Then, ion exchange occurs, indeed. A variety of organo-LDHs, with different combinations of matrix cations as well as different interlayer organic anions, have been prepared using this direct anion-exchange route $[53,60,61]$. Then, these organoLDHs were used in further exchange, when, e.g., polyoxometalate anions could be introduced among the layers, successfully $[62,63]$.

\subsubsection{The dehydration-rehydration method}

This route comprises of using the already discussed "memory effect", i.e., the ability of LDHs to recover their layered structure after dehydrating, but not too severe heat treatment (details are to be seen in section 2.2.). On calcination, the LDHs lose the physisorbed water molecules; then, the interlayer water molecules (and the interlayer anions) are removed. The dehydroxylation of the layers results in the collapse of the layered structure, leading to the formation of mixed metal oxide of basic character with large concentration of surface defect sites. After calcination at moderately high temperature (usually not higher than $773 \mathrm{~K}$ ), the LDH phase can be reconstructed in aqueous solution containing the new anion to be intercalated [64]. Unfortunately, the method does not always work, it, e.g., fails if the anion is tartrate, which has a strong tendency to form complexes with metal ions [65].

A number of studies have been conducted to elucidate the mechanism by which LDHs are reconstructed - they are discussed in section 2.2. Pfeiffer et al. found that relative humidity and temperature are also important variables in this procedure [46]. Kinetic data on the reconstruction of MgAl-LDHs have been obtained by time-resolved energy dispersive Xray diffraction [11].

\subsubsection{The delaminating-restacking method}

Delamination is a process where the layers are separated from each other in a way that there is virtually no interaction among them. This process can be performed thermally (that is heating the sample in an inert atmosphere) or chemically (e.g., by modifying the interlayer region with hydrophilic or hydrophobic guest species). Stirring or sonication is usually applied to achieve the complete delamination of layers and to form a colloidal dispersion of monolayers. During the procedure solvent molecules get into the interlayer space and they promote the separation of the layers or even stabilise the individual ones. The stability of the colloid dispersion can be enhanced by the appropriate choice of intercalant/solvent combination, since the colloidal 
dispersion of the delaminated layers is usually unstable and readily reconstructed. The delamination-restacking process has often been applied for the preparation of various nanocomposites. Using self-assembled aggregates as a template, inorganic minerals or materials, such as LDHs can be directed to an ordered structure with specific morphology and size by replication of the structure of the self-assembled aggregates. Nanosheets show new physical and chemical properties as a result of their extremely low thickness $(\sim 1 \mathrm{~nm})$. They are useful as building blocks for the fabrication of wide variety of functional nanostructured materials [66]. One of the most important and used technique is the layer-by-layer (LbL) assembly process, which is based on the successive deposition of oppositely charged units onto solid surfaces [67-69].

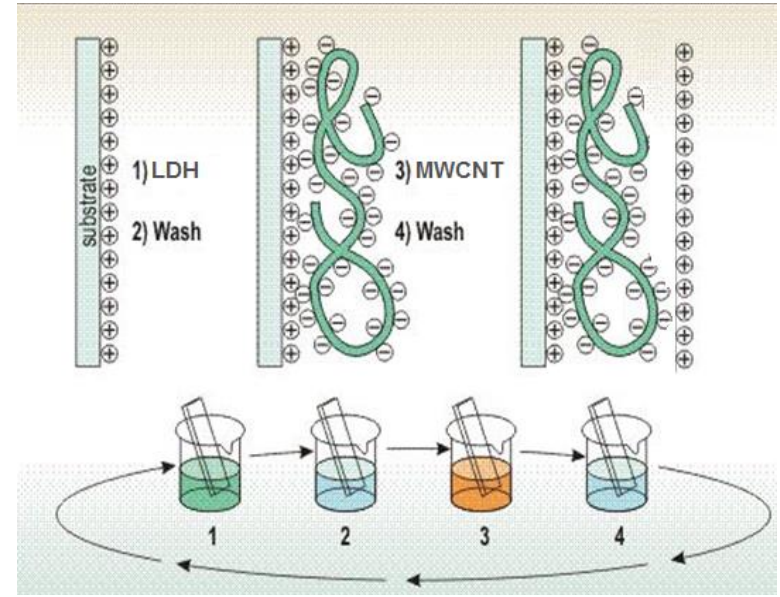

(a)

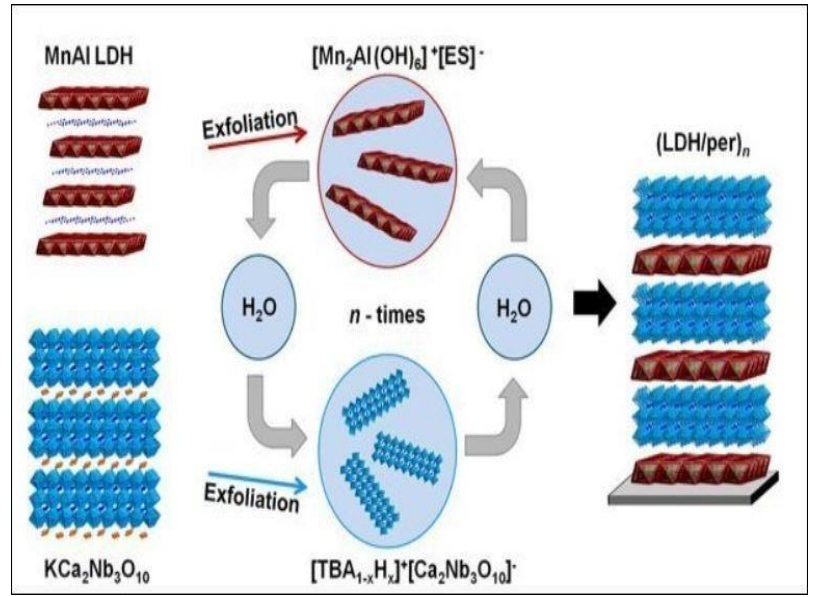

(b)

Figure 9. Schematic representation of the layer-by-layer (LbL) process (a) employed to construct hybrid superlattices (b): Exfoliation of the layered bulk materials into $\mathrm{Mn}_{2} \mathrm{Al}(\mathrm{OH})_{6}{ }^{+}$ $(\mathrm{LDH})$ and $\mathrm{Ca}_{2} \mathrm{Nb}_{3} \mathrm{O}_{10^{-}}$(per) nanosheets is followed by electrostatic LBL assembly with intermediate washing steps in order to achieve $3 \mathrm{D}(\mathrm{LDH} / \mathrm{per})_{n}$ heterostructures immobilised on a substrate [70].

The hydrophilic and positively charged substrate is immersed into the solution of polyanion for several minutes (Figure $9(\boldsymbol{a})$ ). As a result, a thin (mono)layer of the material is adsorbed on the surface. The thickness of the layer formed is of about $1 \mathrm{~nm}$. On the surface, negative charge density is created. Due to electrostatic repulsion, further increase of the thickness or assembling of another charged layer does not take place. Then, the substrate is washed of and placed into a solution of polycation, which is attached to the substrate electrostatically. Again, the further growth of the thickness is blocked, since it is now charged positively and electrostatic repulsion with polymer molecules in the solution takes place. The procedure can be repeated for the necessary number of times providing the layered structure of the required thickness. 
Delamination of layered double hydroxides is difficult, because these solids do not swell in water, and hence aqueous colloidal dispersions of LDH layers are not readily formed. To solve this problem LDHs should be delaminated in organic media. Several groups attempted to delaminate the LDHs in non-aqueous solvents after replacing interlayer inorganic anions with organophilic anions. Adachi-Pagano et al. [71, 72] delaminated dodecyl sulfate-ZnAl-LDHs in alcohols by refluxing them at $393 \mathrm{~K}$. In that case, restacking of the LDH layers was performed in the presence of $\mathrm{Cl}^{-}$or $\mathrm{CO}_{3}{ }^{2-}$ ions by adding an aqueous solution containing their sodium salts to the $\mathrm{NaOH}$. In another approach, amino-carboxylate ions have been intercalated in the interlayer region of the $\mathrm{LDH}$ to achieve delamination in formamide, a polar aprotic solvent [73].

\subsection{Applications of layered double hydroxides}

\subsubsection{General considerations and miscellaneous applications}

The flexibility in the composition of layered double hydroxides resulted in an increased interest for these materials. The LDHs have been used as prepared or (mainly) after calcination. The most interesting properties of the oxides obtained by calcination are the followings:

(i) high specific surface area,

(ii) basic properties (both Brønsted and Lewis basic sites are identified [74]),

(iii) formation of homogeneous mixtures of oxides with very small crystal size, stable to thermal treatments, which by reduction, form small and thermally stable metal crystallites.

(iv) "memory effect", which allows the reconstruction under mild conditions of the original LDH structure.

Properties (i)-(iii) make these materials efficient catalysts, while properties (i), (ii) and (iv) are utilised in applications such as the scavenging of chloride ions and the purification of water containing harmful organic and/or inorganic anions.

An important application of LDHs is in environmental remediation. Today, natural waters and soil are severely contaminated by pesticides and industrial wastes. LDHs can take up a variety of contaminants and toxic substances directly from the environment through anion exchange, reconstruction, and adsorption, as it is seen in Figure 10. 


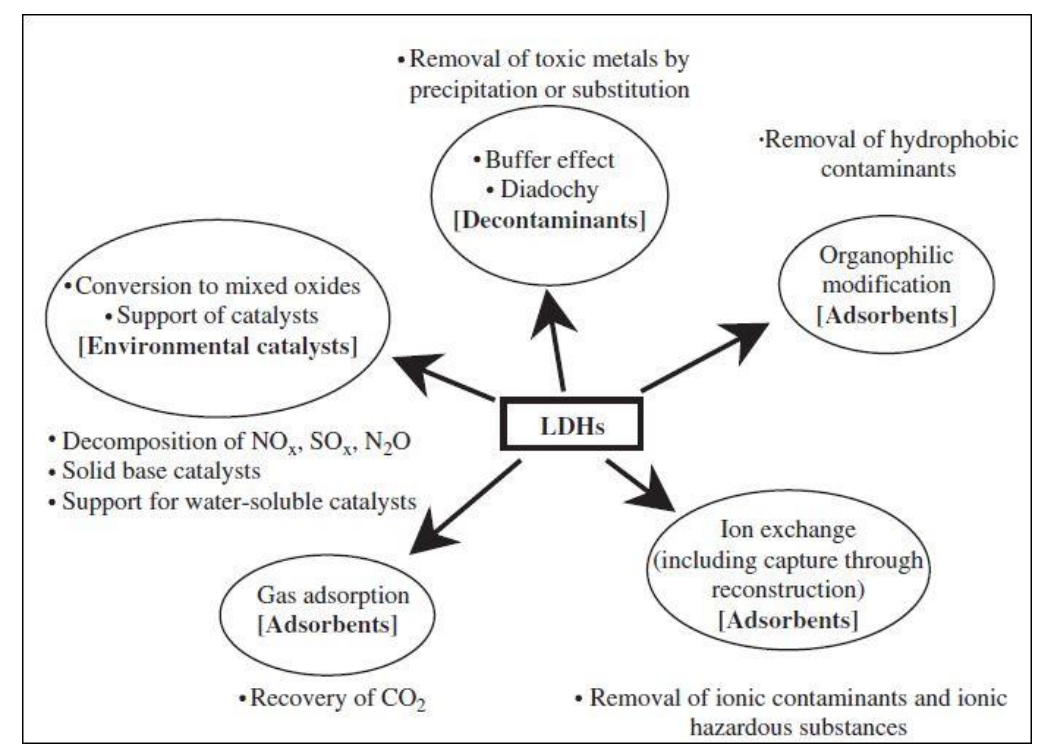

Figure 10 Environmental applications of LDHs [44].

Another application is in medicine, especially in pharmaceutical formulations. Studies have concentrated on the intercalation and controlled release of pharmaceutically active compounds from LDH materials, taking advantage of their variable chemical composition, ability to intercalate anionic drugs, and their alkaline character. In the interlayer region of LDHs, the drug is stored in anionic form; it maintains its integrity, and is protected from undesired interactions with light and oxygen. Such a drug delivery system could also reduce the side effects of drugs. The rate of drug diffusion out of the intercalated compound is controlled by the strength of the host-guest interaction, the rigidity of the layers and the diffusion path length [75].

\subsubsection{LDH-hosted composite materials}

Recently, the selective production of composite materials became very important. Some inorganic/inorganic [28], organic/inorganic [76], and bio/inorganic [77] systems that have attracted considerable interest due to their unusual physicochemical properties cannot be achieved by conventional solid-state reactions. Compounds that are commonly used for producing nanocomposites, for instance, silicates $[78,79]$ and montmorillonite (MMT), have been widely used and investigated [80, 81]. Combining such materials with one-dimensional nanowires/nanotubes and two-dimensional lamellar flakes led to three-dimensional hierarchical nanocomposites with unexpected properties for unique applications [82, 83]. For instance, the combination clay-polymer composites and clay-carbon nanotube (CNT) nanocomposites show extraordinary mechanical and energy-absorbing properties [83]. The key issue for the successful application of nanocomposites lies in the peculiarities of 
arranging the two phases (filler and matrix) into a well-designed structure. Layered double hydroxides are among the most promising inorganic structures for making composite or nanocomposite materials. Literature analysis reveals that there are two significant groups of composites depending on the role of LDHs. One is where the LDHs form the matrices, and the other is where the LDHs are the guest materials. Papers dealing with the first group are more abundant than those concerned with the other one. As our experimental work did not touch this latter area, related articles will not be discussed here.

There are several methods to prepare LDH/composites or nanocomposites, such as coprecipitation, ion exchange, surfactant-mediated incorporation, hydrothermal treatment, reconstruction (using the memory effect), or delamination followed by restacking [80]. The properties of composites/nanocomposites are all dependent on the dispersion. A homogeneous dispersion of nanoparticles is believed to contribute better to property improvement. Thus, one can prepare new composite materials with enhanced mechanical, gas barrier and flame retardant properties $[76,84]$.

\subsubsection{Nanocarbon-LDH nanocomposites}

Nanocarbons and layered double hydroxides were intensly investigated recently because of their excellent properties [82, 85-87]. The combination of these one- and two-dimensional building blocks leads to the formation of hierarchical composites that can take full advantage of each kind of material: nanocarbons can provide the good electrical conductivity and high mechanical strength, and LDHs can provide good chemical reactivity.

According to their wall numbers, carbon nanotubes can be classified into single-walled CNTs (SWCNTs) and multi-walled CNTs (MWCNTs). The former can be considered as a cylindrical tube formed by rolling up a single-layer graphene sheet. The latter one can be considered as an array of such nanotubes that are coaxially nested. The excellent electrical and thermal properties of CNTs facilitate their applications in the field of electrical devices, energy conversion and storage, transparent conductive films, field emission displays, thermal interface materials, etc. [88].

When nanostructures composed of CNTs and LDHs are concerned, several structural varieties proved to be feasible (Figure 11). They are as follows [82]:

(a) carbon nanotubes uniformly attached to the surface of LDH flakes,

(b) intercalation of CNTs into the interlayer space of LDHs,

(c) in situ grown LDHs on the surface of carbon nanotubes,

(d) randomly entangled CNTs grown from layered double hydroxides, 
(e) aligned carbon nanotube arrays grown from $\mathrm{LDHs}$,

(f) CNT-array double helix grown from layered double hydroxides.

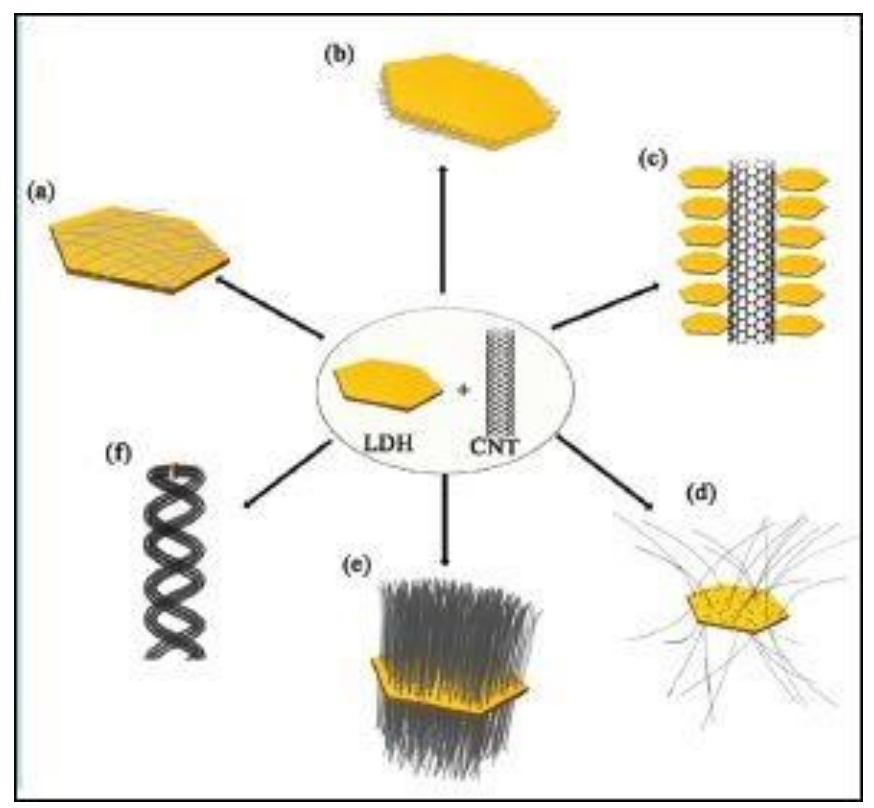

Figure 11 Schematic illustration showing CNT-LDH nanocomposites described in the literature: (a) CNTs uniformly attached to the surface of LDH flakes, (b) intercalation of CNTs into the interlayer space of LDHs, (c) LDHs in situ grown on the surface of CNTs, $(d)$ randomly entangled CNTs grown from $\mathrm{LDHs}$, (e) aligned CNT arrays grown from $\mathrm{LDHs}, f$ ) CNT-array double helix grown form LDHs [82].

The CNT-LDH composite with unique 3D nanostructure is a novel nanomaterial, which combines 2D LDH nanosheets and 1D carbon nanotubes together. These hierarchical nanostructures can serve as electrodes, sensors as well as electric circuit elements after appropriate modification, and have promising applications as electrocatalysts [89] or in hydrogen storage devices [90]. This kind of composite has mostly been prepared by in situ growth of CNTs on LDH [87, 90], co-precipitation method [89] or wet mixing [86].

Huang et al. [86] presented a simple method for preparing exfoliated CNT-LDH hybrids through mixing positively charged LDHs and negatively charged CNTs. They even proposed a model to describe the co-assembling process.

Pradhan et al. [91] have prepared MWCNT-LDH hybrids by the simple dry grinding of various LDHs (LiAl-LDH, MgAl-LDH and CoAl-LDH) with MWCNT. The obtained MWCNT-LDH hybrids were used to fabricate silicone rubber composites.

Yang et al. [92] successfully synthetized a nanostructured CNT-LDH composite by the simple precipitation technique via the electrostatic interaction between positively charged 
LDH layers and the negatively charged functional groups on the modified CNTs. The composite was applied as the anode in a $\mathrm{Ni} / \mathrm{Zn}$ cell.

Graphene, a 2D monolayer sheet of $\mathrm{sp}^{2}$ hybridized carbon atoms is believed to be the basic building block of various carbon allotropes. It is also an excellent building block for 3D hierarchical nanocomposites. Li et al. [85] prepared a hybrid graphene-NiFe-LDH material under mild hydrothermal conditions. It has been found that during the synthesis procedure, the exfoliated graphite oxide (GO) is simultaneously reduced to graphene along with the homogeneous precipitation of NiFe-LDH.

\subsubsection{Polymer-LDH guest-host nanocomposites}

Synthetic LDHs are commonly combined with polymers. Figure 12 presents some synthesis strategies to incorporate the polymer in the interlayer space of LDH. Schöllhorn et al. [93] distinguished three principal options to obtain a polymer intercalated inorganic host:

(a) direct intercalation of extended polymer chains in the host lattice,

(b) transformation of the host material into a colloidal system and precipitation in the presence of the polymer,

(c) intercalation of the monomer molecules and subsequent in situ polymerisation.

Another opportunity is using the reconstruction ability of LDHs, i.e., the previously heat-treated and collapsed LDH systems recovers in an aqueous environment, in the presence of the polymer with concomitant intercalation.

Finally, a post-synthetic hydrothermal treatment can be applied in all cases, which may improve the inter- and intralamellar organisations of the polymer-LDH nanocomposites.

The first method involving the incorporation of the polymer as a whole, was applied in the intercalation of poly(acrylic acid), poly(vinyl sulfonate), poly(styrene sulfonate) and poly(ethylene glycol) alkenyl sulfonic acid into LDH [94, 95]. Generally, the incorporation of polymer chains of small molecular weight was done via ion-exchange reactions. While the second method, the co-precipitation route that is, allowed the incorporation of larger molecules. This method can be considered as a self-assembly process involving the in situ formation of $\mathrm{LDH}$ layers around the polymer intercalate [76]. 


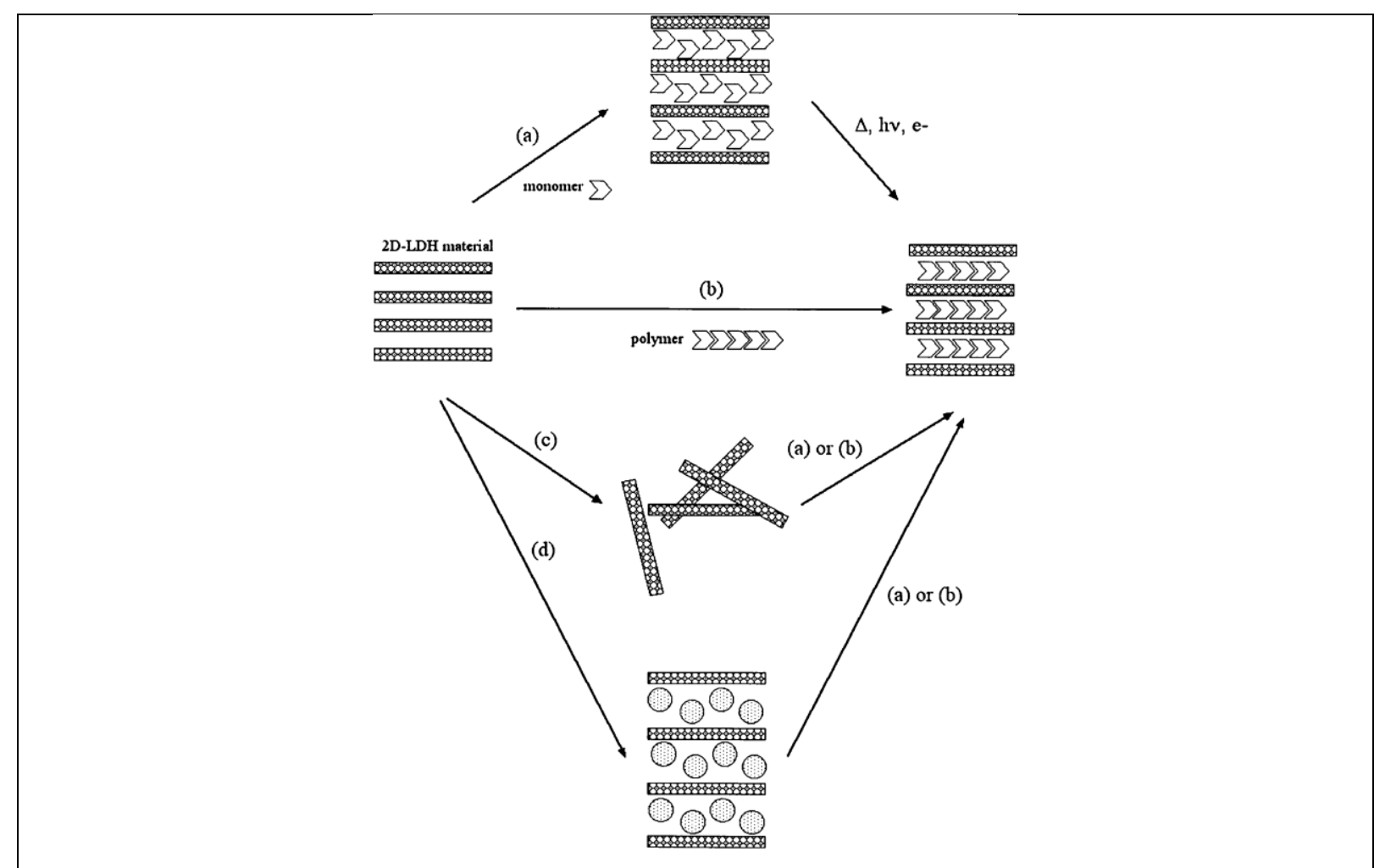

Figure 12 Scheme of the preparation of polymer-LDH nanocomposites: (a) in situ polymerization, $(b)$ direct incorporation of polymer, $(c)$ restacking or reconstruction, and $(d)$ guest displacement or solvent-assisted method [1]. 


\section{EXPERIMENTAL}

\subsection{Materials}

For the synthesis of the LDHs, the following compounds were used as received, without further purification: calcium chloride $\left(\mathrm{CaCl}_{2}\right.$, Molar Chemicals, puriss), iron chloride $\left(\mathrm{FeCl}_{3} \cdot 6 \mathrm{H}_{2} \mathrm{O}\right.$, Molar Chemicals, puriss special), hydrogen chloride $(20 \mathrm{w} / \mathrm{w} \% \mathrm{HCl})$ solution, sodium hydroxide pellets (NaOH, VWR, a.r. grade). Sodium dodecylbenzenesulfonate (DBS, Sigma-Aldrich, technical grade) was applied for various purposes like wrapping multiwall carbon nanotubes (MWCNT) or in delamination. N,N-Dimethylformamide (DMF, 99\%, Merck) and hexamethylenetetramine (hexamine, Merck, a.r. grade) were the solvents used for delaminating the LDHs. The acids (cc. $\mathrm{H}_{2} \mathrm{SO}_{4}$ and fuming $\mathrm{HNO}_{3}$ ), applied for treating MWCNTs, were the products of Reanal. MWCNTs were synthesised in our laboratory via the chemical vapour deposition (CVD) method. Polyacrylate anions (sodium polyacrylate of $\mathrm{M}_{\mathrm{r}}$ $\sim 1200$ g/mol, Sigma-Aldrich) were intercalated into CaFe-LDH. Millipore MilliQ water and $\mathrm{N}_{2}$ gas $(99.95 \%)$ were used throughout the experiments.

\subsection{Preparation of carbonate-free and concentrated $\mathrm{NaOH}$ solution}

Concentrated $\mathrm{NaOH}(\sim 20 \mathrm{M})$ stock solution was made from distilled water and a.r. grade solid $\mathrm{NaOH}$. Its carbonate content was minimised. The solution was filtered on polysulphone Nalgene filter, after the precipitation of the sodium carbonate [96]. Pycnometer was used to determine the exact density of the solution. The concentration of the solution was calculated from the known density $v s$. concentration curve of sodium hydroxide [97]. $\mathrm{NaOH}$ solutions of various concentrations were made from this stock solution right before the synthesis.

\subsection{Synthesis of layered double hydroxides}

For the synthesis of the CaFe-LDH the co-precipitation method was used [98]. The aqueous solution of $3: 1$ or 2:1 molar ratio from a mixture of $\mathrm{CaCl}_{2}$ and $\mathrm{FeCl}_{3} \cdot 6 \mathrm{H}_{2} \mathrm{O}(100.0$ $\mathrm{cm}^{3}$ solution of 0.3 or $0.2 \mathrm{M}$ and $0.1 \mathrm{M}$, respectively) were transformed into LDH with carbonate-free $3 \mathrm{M}$ aqueous $\mathrm{NaOH}$ via slowly raising the $\mathrm{pH}$ of the solution to 13 under $\mathrm{N}_{2}$ protecting gas. Under these conditions, the materials precipitated with layered structure. 


\subsection{Method of dehydration and rehydration}

The as-prepared air-dry LDH was heat treated in $\mathrm{N}_{2}$ atmosphere at $773 \mathrm{~K}$ for $5 \mathrm{~h}$. After this, portions of the obtained dehydrated materials were kept under preset and controlled relative humidity $(\mathrm{RH})$ values for two weeks [99].

The RH\% values were set with the help of the following saturated salt solutions (Table 1):

Table 1 Materials used for setting relative humidity values.

\begin{tabular}{ccc}
\hline Relative Humidity & Compound used & Producer \\
\hline $\mathbf{6 \%}$ & Lithium bromide $\left(\mathrm{LiBr} 2 \mathrm{H}_{2} \mathrm{O}\right)$ & Sigma-Aldrich \\
$\mathbf{9 \%}$ & Potassium hydroxide $(\mathrm{KOH})$ & Molar \\
$\mathbf{1 1 \%}$ & Lithium chloride $\left(\mathrm{LiCl} \mathrm{H}_{2} \mathrm{O}\right)$ & Fluka \\
$\mathbf{2 2 \%}$ & Sodium acetate $\left(\mathrm{CH}_{3} \mathrm{COONa}\right)$ & Reanal \\
$\mathbf{2 9 \%}$ & Calcium chloride $\left(\mathrm{CaCl}_{2} 6 \mathrm{H}_{2} \mathrm{O}\right)$ & Reanal \\
$\mathbf{3 3 \%}$ & Magnesium chloride $\left(\mathrm{MgCl}_{2} 6 \mathrm{H}_{2} \mathrm{O}\right)$ & Sigma-Aldrich \\
$\mathbf{3 8 \%}$ & Sodium iodide $\left(\mathrm{NaI}_{2} \mathrm{H}_{2} \mathrm{O}\right)$ & Sigma-Aldrich \\
$\mathbf{4 3 \%}$ & Potassium carbonate $\left(\mathrm{K}_{2} \mathrm{CO} 3\right)$ & Fluka \\
$\mathbf{5 3 \%}$ & Magnesium nitrate $\left(\mathrm{Mg}\left(\mathrm{NO}_{3}\right) 26 \mathrm{H}_{2} \mathrm{O}\right)$ & Molar \\
$\mathbf{6 2 \%}$ & Ammonium nitrate $\left(\mathrm{NH}_{4} \mathrm{NO}_{3}\right)$ & Sigma-Aldrich \\
$\mathbf{7 5 \%}$ & Sodium chloride $\left(\mathrm{NaCl}_{3}\right)$ & Molar \\
$\mathbf{8 4 \%}$ & Potassium chloride $\left(\mathrm{KCl}^{2}\right)$ & Molar \\
$\mathbf{9 7 \%}$ & Potassium sulfate $\left(\mathrm{K}_{2} \mathrm{SO}_{4}\right)$ & Sigma-Aldrich \\
\hline
\end{tabular}

\subsection{Synthesis methods of carbon nanotube-layered double hydroxide nanocomposites}

It was revealed very quickly that the dehydration-rehydration method could not produce carbon nanotube-layered double hydroxide.

The other sample preparation method tried, was co-precipitation [1]. The first step of all synthetic experiments was the preparation of an acidic $(\mathrm{pH}=1.7)$ solution containing $\mathrm{CaCl}_{2}$ and $\mathrm{FeCl}_{3}$ in 2:1 molar ratio. The last step was setting the final $\mathrm{pH}$ to 13.

Acid treatment of MWCNTs was employed for oxidatively generating dislocations containing hydroxylic and/or carboxylic groups. In order to achieve this goal, $2.4 \mathrm{~g}$ MWCNT was suspended in the mixture of cc. $\mathrm{H}_{2} \mathrm{SO}_{4}\left(45 \mathrm{~cm}^{3}\right)$ and fuming $\mathrm{HNO}_{3}\left(15 \mathrm{~cm}^{3}\right)$ at $323 \mathrm{~K}$ for $24 \mathrm{~h}$. Then, the acid-treated MWCNT was washed to neutral $\mathrm{pH}$, and dried over $\mathrm{P}_{2} \mathrm{O}_{5}$. 
Three modifications of the co-precipitation method were tested:

In method (A) $0.1-0.3 \mathrm{~g}$ of pristine or acid-treated MWCNT was added to $100 \mathrm{~cm}^{3}$ of the above-described solution either without or together with $0.3 \mathrm{~g}$ of DBS under $\mathrm{N}_{2}$ atmosphere with 30 min stirring. After precipitating the substances with $3 \mathrm{M} \mathrm{NaOH}$, the samples were stirred at $353 \mathrm{~K}$ for one week.

In method (B), the pristine or acid-treated MWCNT $(0.1-0.3 \mathrm{~g})$ alone or together with DBS (0.3 g) were dispersed or dissolved in amounts of $3 \mathrm{M} \mathrm{NaOH}$ necessary for coprecipitation, and then, the $\mathrm{Ca}(\mathrm{II})$ - and $\mathrm{Fe}(\mathrm{III})$-containing solution was added dropwise under $\mathrm{N}_{2}$ atmosphere. Constant stirring was maintained for an additional week at room temperature.

In method (C), the acid-treated MWCNT was dispersed in $3 \mathrm{M} \mathrm{NaOH}$ by sonication (5 $\mathrm{h}$ ), and then, the solution containing the salt mixture was added in one portion. Sonication was continued for additional $3 \mathrm{~h}$. Then, stirring with a mechanical stirrer under $\mathrm{N}_{2}$ atmosphere was applied for one week.

All samples were vacuum-filtered on Versapor-129 membrane and were kept in desiccator over $\mathrm{P}_{2} \mathrm{O}_{5}$.

The goal of the delamination experiments $[66,100]$ was preparing disaggregated LDHs for use in the layer-by-layer (LbL) experiments [68], in which placing layers of LDH and MWCNTs on the top of each other was attempted. Experiments were performed in two ways. Method (D): $0.4-0.5 \mathrm{~g}$ of LDH intercalated with DBS was suspended in $100 \mathrm{~cm}^{3}$ of DMF, then, stirred for further two days under $\mathrm{N}_{2}$ atmosphere at room temperature. Method (E): $5 \mathrm{~g}$ of hexamethylenetetramine (hexamine) was dissolved in $160 \mathrm{~cm}^{3}$ water and to $80 \mathrm{~cm}^{3}$ of it 0.4-0.5 g CaFe-LDH was added. In the other $80 \mathrm{~cm}^{3}, 0.4-0.5 \mathrm{~g}$ DBS-LDH was suspended. Both mixtures were stirred at $383 \mathrm{~K}$ for 24 hours, then $50 \mathrm{~cm}^{3}$ DMF was added and stirring was continued for an additional day.

Quartz slides used for the LbL experiments were cleaned as follows: immersing into 1:1 mixture of $20 \mathrm{w} / \mathrm{w} \% \mathrm{HCl}$ and methanol (20 min), rinsing with distilled water, immersing into cc. $\mathrm{H}_{2} \mathrm{SO}_{4}(20 \mathrm{~min})$, rinsing with distilled water, immersing into $20 \mathrm{M} \mathrm{NaOH}(24 \mathrm{~h})$, finally, rinsing with distilled water before use.

In an LbL experiment, the following sequence was used: (i) dipping the quartz slide into suspension (D) or (E) for $20 \mathrm{~min}$, (ii) cautiously rinsing it with distilled water, (iii) dipping the treated quartz slide into a suspension of pristine carbon nanotubes $(0.3 \mathrm{~g}$ nanotube suspended in $250 \mathrm{~cm}^{3}$ of distilled water), (iv) then rinsing it with distilled water once again. This sequence was repeated five more times. 


\subsection{Intercalation of polyacrylate in LDHs}

Polyacrylate anions were intercalated into $\mathrm{CaFe}-\mathrm{LDH}$ with the dehydration-rehydration method, utilising the "memory effect" of the layered double hydroxides.

A typical recipe is as follows. $\mathrm{CaFe}-\mathrm{LDH}$ was prepared by the co-precipitation method as described above. The host materials were calcined at $773 \mathrm{~K}$ for $5 \mathrm{~h}$ in $\mathrm{N}_{2}$ atmosphere before intercalation. $5 \mathrm{~cm}^{3}$ polyacrylate solution $(45 \mathrm{w} / \mathrm{w} \%)$ was suspended in a solution containing $10 \mathrm{~cm}^{3}$ water, $10 \mathrm{~cm}^{3}$ sodium hydroxide $(3 \mathrm{M})$ and $50 \mathrm{~cm}^{3}$ ethanol. The calcined layered double hydroxide $(2.5 \mathrm{~g}$ ) was added to this solution, and the mixture was stirred for one week at $353 \mathrm{~K}$ under $\mathrm{N}_{2}$ atmosphere. Upon rehydration intercalation occurred. The solid material was filtered and washed with distilled water. The crystals obtained were kept at room temperature in a desiccator over $\mathrm{P}_{2} \mathrm{O}_{5}$.

\subsection{Characterisation methods}

\subsubsection{X-ray diffractometry}

The fundamental method for studying LDHs is powder X-ray diffractometry (XRD). The diffractograms were taken in the $2 \Theta=3-60^{\circ}$ range on Rigaku Miniflex II instruments, using $\mathrm{CuK}_{\alpha}(\lambda=1.5418 \AA)$ radiation in Bragg-Brentano geometry. Reflection positions were determined via fitting a Gaussian function. They were found to be reproducible within $0.05^{\circ}$ $(2 \Theta)$; therefore, the uncertainty of the basal spacing was estimated as $\pm 0.01 \mathrm{~nm}$.

\subsubsection{In situ X-ray diffractometry}

The in situ XRD measurements were carried out at MAX-lab, beamline I711. Beamline I711 is a crystallography beamline used for single crystal and powder diffraction. It utilises a 13-period, $1.8 \mathrm{~T}$, multipole wiggler designed to operate in the $0.85(14.6 \mathrm{keV})$ to $1.55 \AA$ (8.0 $\mathrm{keV}$ ) region. The beamline has a single crystal monochromator which provides a high photon flux at the sample, while sacrificing easy tunability and high energy resolution. The experimental setup is a 4-circle diffractometer with $\kappa$ geometry, capable of performing both single crystal and powder diffraction measurements using a large area CCD detector. 


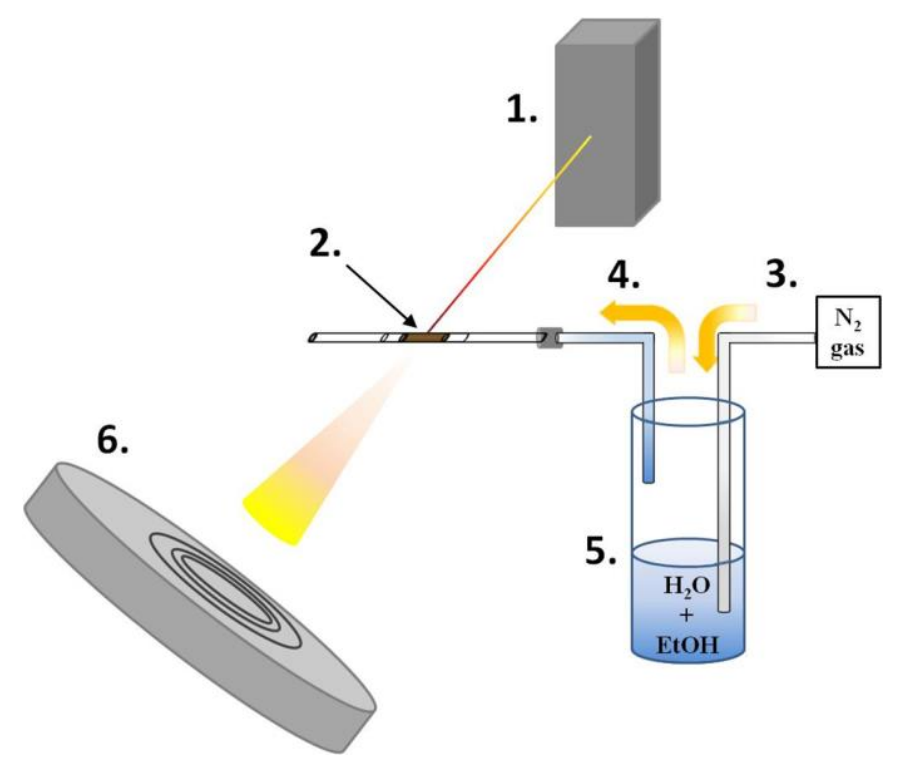

Figure 13 Scheme of the experimental setup: 1. X-ray source; 2. powdered sample; 3. dry $\mathrm{N}_{2}$ gas; 4. $N_{2}$ gas saturated with the solvent mixture; 5. ethanol/water mixture (9:1 volume ratio);6. area detector.

$50 \mathrm{mg}$ of dehydrated $(473 \mathrm{~K}, 2 \mathrm{~h}$ ) LDH samples (CaFe-LDH or MgAl-LDH) were placed in a quartz capillary (inner diameter: $1 \mathrm{~mm}$ ), loosely plugged with cotton at both sides. Aqueous ethanol (1:9 volume ratio) was bubbled through it, applying $\mathrm{N}_{2}$ as carrier with a flow rate of $10 \mathrm{~cm}^{3} / \mathrm{min}$ at $298 \mathrm{~K}$. Diffractograms were collected at the middle of the sample.

\subsubsection{Thermal analytical measurements}

Thermal analytical measurements (TG/DTG) were performed using a Setaram Labsys derivatograph working under $\mathrm{N}_{2}$ flow at $2{ }^{\circ} \mathrm{C} / \mathrm{min}$ heating rate on $30-40 \mathrm{mg}$ sample. Both the weight loss vs. temperature (thermogravimetric - TG) and the differential weight loss $v s$. temperature (differential thermogravimetric - DTG) curves were recorded. Approximately $20 \mathrm{mg}$ sample (weighed accurately into a ceramic crucible sample holder) was used in each experiment. Measurements were started right after removing the samples from the desiccators.

\subsubsection{Microscopies}

The morphology of the samples was examined by scanning electron microscopy (SEM - Hitachi S-4700 microscope with varied acceleration voltages). The samples were ground before fixing them on double-sided adhesive carbon tape. They were coated with gold to avoid charging using a sputter coater (Quorum Technologies SC7620). The thickness of the gold layer was a few nanometers. The approximate composition and the elemental map of the 
substances were obtained by a Röntec QX2 energy dispersive X-ray spectrometer (EDX) coupled to the microscope.

The layer thickness of the CaFe-LDH sample was estimated from a transmission electron microscopic (TEM) dark-field image taken by a FEI TECNAI G 20 X-TWIN microscope at $200 \mathrm{kV}$ accelerating voltage. Samples of the material to be analysed were suspended in absolute ethanol by means of an ultrasound bath. The mixture was placed on a lacey carbon 200 mesh copper grid and the solvent was allowed to evaporate.

\subsection{5. ${ }^{57}$ Fe Mössbauer spectroscopy}

${ }^{57} \mathrm{Fe}$ Mössbauer spectra of the samples were recorded with conventional Mössbauer spectrometers (Wissel and Ranger) in transmission geometry at $78 \mathrm{~K}$ or $295 \mathrm{~K} . \mathrm{A}{ }^{57} \mathrm{Co} / \mathrm{Rh} \gamma-$ radiation source of $3 \times 10^{9} \mathrm{~Bq}$ activity was used. The spectrometers were calibrated with $\alpha$-iron at room temperature. Spectrum evaluation was carried out using the MOSSWIN code via fitting Lorentzian curves [101].

\subsubsection{FT-IR spectroscopy}

The Fourier-transform infrared (FT-IR) spectra of the pristine and the organic anionintercalated LDH samples were recorded on a BIORAD FTS-65A/896 spectrometer equipped with a DTGS detector in diffuse reflectance. Spectral resolution was $4 \mathrm{~cm}^{-1}$, and 256 scans were collected for a spectrum. The spectra were baseline corrected and smoothed using the WIN-IR software package. The samples were finely ground and combined with $\mathrm{KBr}$ (without pressing into pellets).

\subsubsection{Dielectric relaxation spectroscopy (DRS)}

DRS measurements were used for studying the relaxation processes of CaFe-LDH. Broadband dielectric relaxation spectroscopy (DRS) is a technique based on the interaction of an external electromagnetic field with the electric dipole moment of the sample [102]. This technique can be used for studying the molecular dynamics of the water molecules. The LDH powder may be regarded as a heterogeneous system, in which various water types are present in a confined environment at different positions and interfaces. The dielectric properties of water molecules at these different locations and interfaces should be reflected in the DRS spectrum, thus, it is expected that the gradual rehydration of the dehydrated LDH can be followed.

Since DRS is a less frequently used experimental technique, in the followings, I give a more detailed description than it was done for the other more commonly used methods. 
In a dielectric measurement, a voltage $U_{0}$ with a fixed frequency $\omega / 2 \pi$ is applied to a sample cell containing the sample material under testing. $\mathrm{U}_{0}$ results in a current $\mathrm{I}_{0}$ at the same frequency in the sample cell, and the phase shift between the current and the voltage, described by the phase angle $\varphi$. The ratio between $\mathrm{U}_{0}$ and $\mathrm{I}_{0}$ and the phase angle $\varphi$ are determined by the electric properties (permittivity and conductivity) of the material and the sample geometry. For easy calculation and representation of the formulae, it is convenient to use complex notation.

$$
\begin{array}{r}
U(t)=U_{0} \cos (\omega \cdot t)=\operatorname{Re}\left(U^{*} e^{i \omega t}\right), \\
I(t)=I_{0} \cos (\omega \cdot t+\varphi)=\operatorname{Re}\left(I^{*} e^{i \omega t+\varphi}\right),
\end{array}
$$

with $U^{*}=U_{0}$ and $I^{*}=I^{\prime}+i I^{\prime \prime}, I_{0}=\sqrt{I_{1}^{\prime 2}+I_{1}^{\prime \prime 2}}, \operatorname{tg}(\varphi)=\frac{I^{\prime \prime}}{I^{\prime}}$

For a sample with linear electromagnetic response, the observed impedance of the sample capacitor:

$$
Z^{*}=Z^{\prime}+i Z^{\prime \prime}=\frac{U^{*}}{I^{*}}
$$

is connected with the dielectric function of the sample material by

$$
\varepsilon^{*}(\omega)=\varepsilon^{\prime}(\omega)-\varepsilon^{\prime \prime}(\omega)=\frac{1}{i \omega C_{0} Z^{*}(\omega)}
$$

Where $\varepsilon^{*}(\omega)$ is the complex dielectric funtion, $\varepsilon^{\prime}(\omega)$ is the real and $\varepsilon^{\prime \prime}(\omega)$ is the imaginary part, $\mathrm{C}_{0}$ is the capacity of the empty sample capacitor. The dielectric function can be expressed, if necessary, in the other formalism as well.

Dielectric relaxation spectra were registered on a Novocontrol Alpha-A FRA instrument, in the $5 \times 10^{-3}-10^{7} \mathrm{~Hz}$ range [103]. The setup for registering the DR spectra is displayed in Figure 14.

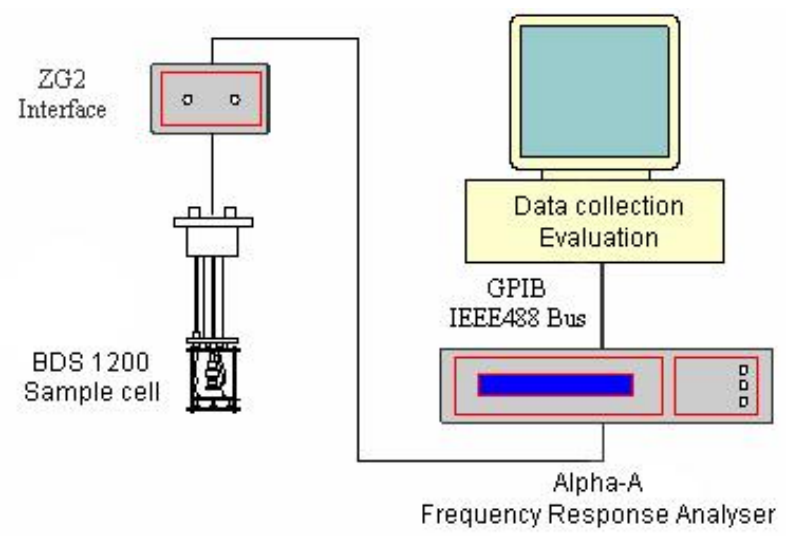

Figure 14 The arrangement used for registering the DRS spectra [103].

A somewhat modified BDS1200 sample holder was connected to a ZG2 interface optimised for dielectric, conductivity and impedance measurements of components or 
materials. The interface includes all components which are critical for wide-band, wideimpedance range and highly accurate measurements, like an output amplifier, a current to voltage converter and reference capacitors. This interface was connected to the Alpha-A head unit, where the sinus generator and the correlators for the lock-in measurements are found.

The Alpha Analyzer measures the complex dielectric conductivity and impedance functions of the samples with high impedance and low loss factors over a broad frequency range, but can accurately measure highly conductive specimens with low impedance, too.

The units were connected with BNC cables. Data were collected with a PC, and WinDETA 5.56, a dielectric spectra evaluation software [104] was used.

The dielectric properties were measured by inserting the sample powder into a concentric cylindrical capacitor. To avoid density-dependent conductivity variation [105, 106], the sample was measured in powder form without pressing it into a pellet.

The samples were measured by a concentric cylindrical capacitor, which is derived from the Novocontrol BDS1307 sample holder [107]. The electrodes are made of stainless steel, the insulation panels are made of Teflon.

The sample cell is placed between the parallel plate electrodes of the Novocontrol sample cell for dielectric measurements. The schematic view of cylindrical sample cell is shown in Figure 15.

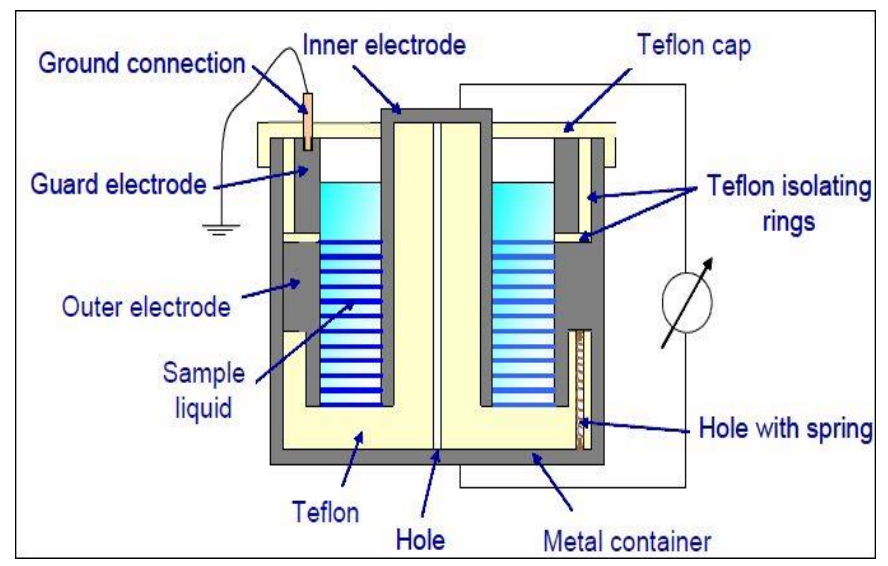

(a)

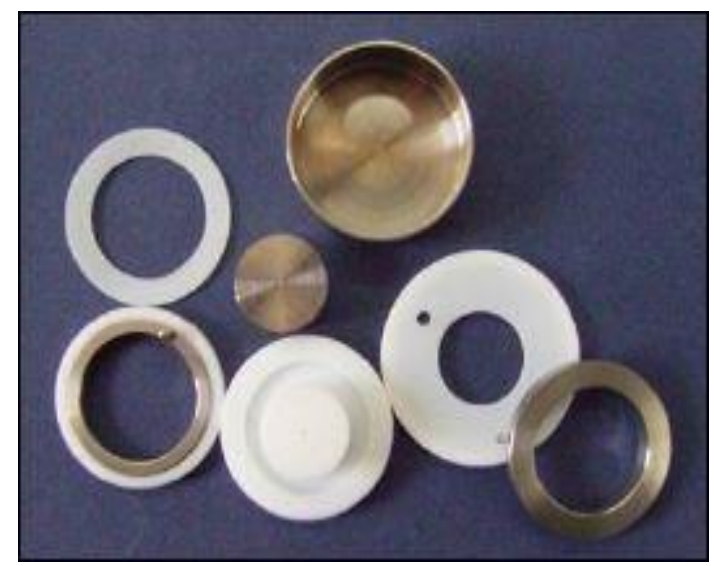

(b)

Figure 15 The schematics of the assembled (a) sample cell and (b) the components of the cell [107].

The Teflon part should be placed inside the metal container. A special small hole in the Teflon allows air to escape from the empty volume smoothly, without any warping during the installation. 
The inner electrode looks like a cap, and covers the central column of the Teflon part in order to reduce any parasite capacitance between the inner electrode and the metal container.

The outer electrode and the metal container are connected by a spring in order to maintain a good electric contact through a wide temperature interval.

The outer electrode and the guard electrode are isolated one from another by a thin Teflon isolating ring. The guard electrode is isolated from the metal container by means of an additional Teflon isolating ring, and is grounded using the connecting wire to the grounded parts of the original Novocontrol sample cell.

\subsubsection{The method of measurement at low temperature}

In dielectric spectroscopy, measuring the temperature dependence of parameters characterising the dielectric response of the materials is of great importance. Since small dipoles often exhibit very short relaxation times near room temperature, for the investigation of most materials, very low temperatures need to be reached. In addition, measurements under isothermal conditions are highly recommended for detailed analysis of the dielectric response. The arrangement for the low-temperature measurements is seen in Figure 16.

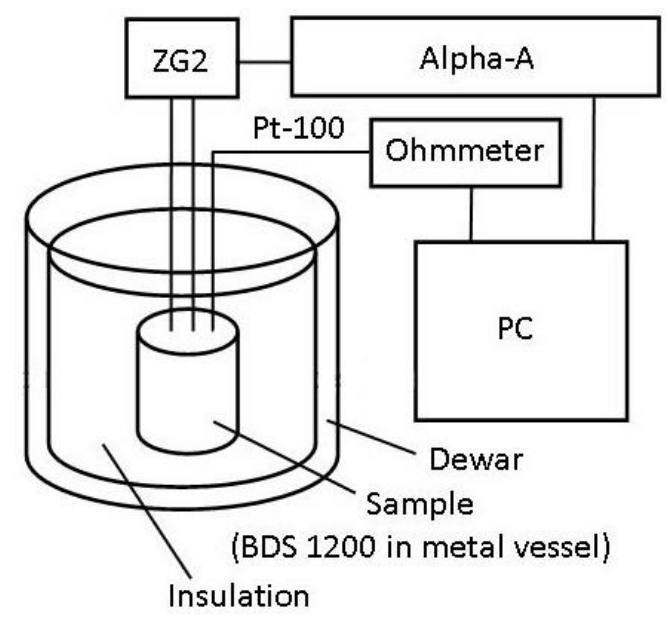

Figure 16 Schematic representation of the home-made cooling system.

The dielectric measurements were carried out under isothermal conditions. The temperature was controlled by a home-made cryosystem, with temperature stability better than $0.5 \mathrm{~K}$. The temperature was increased stepwise from 155 to $283 \mathrm{~K}$ in $2.5 \mathrm{~K}$ steps. 


\section{RESULTS AND DISCUSSION}

\subsection{Preparation and characterisation of CaFe-LDHs}

Our samples, prepared via the co-precipitation of a 2:1 or 3:1 molar mixture of $\mathrm{CaCl}_{2}$ and $\mathrm{FeCl}_{3}$ were $\mathrm{CaFe}$-layered double hydroxides, indeed. It was revealed by the off-white colour of the samples, the XRD data and the SEM-EDX elemental maps of $\mathrm{Ca}$ and $\mathrm{Fe}$. Typical $\mathrm{d}(003)$ data for the fully hydrated $\mathrm{Ca}_{2} \mathrm{Fe}-$ and $\mathrm{Ca}_{3} \mathrm{Fe}-\mathrm{LDH}$ samples are 0.78 and 0.77 $\mathrm{nm}$, respectively [108]. In a parallel experimental study, it was revealed [109], in accordance with older [110] and very recent [111] studies, that phase-pure LDH could only be obtained when the molar ratio of the components was 2:1. However, we have found that the phase-pure LDH cannot be used in long-term applications, since it slowly but surely decomposes when exposed to air. The sample of 3:1 nominal molar ratio contained small amount $(\sim 10 \mathrm{w} / \mathrm{w} \%)$ of $\mathrm{Ca}(\mathrm{OH})_{2}$, and this impurity stabilised the LDH. Since our longer-running project involves the preparation of LDH intercalated with organic anions of various kinds, and exploring their application possibilities as functional materials, we concentrated our efforts on this stable but not fully phase-pure LDH sample.

SEM images revealed hexagonal, platelet-like morphology (Figure 17).
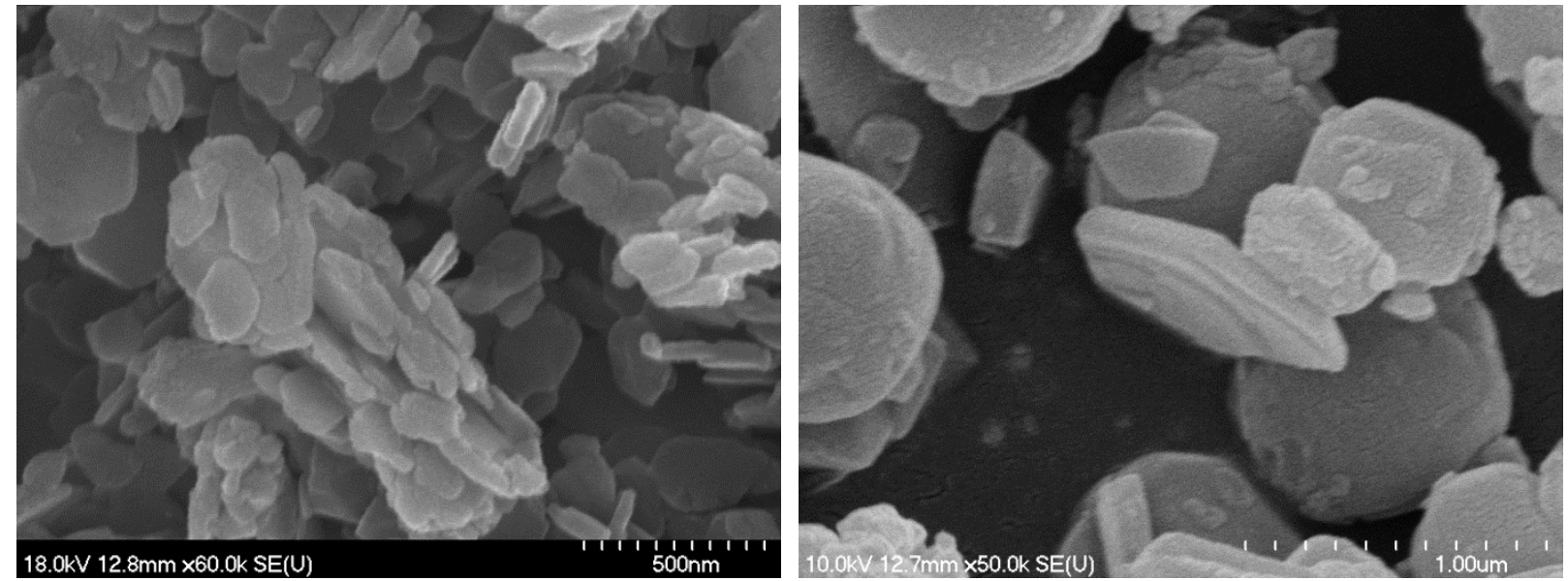

Figure 17 SEM images of CaFe-LDH at various magnifications.

The hexagonal shape and even the layered structure are clearly seen in the TEM image (Figure 18). Note that LDHs can have quite different morphologies depending on the intercalated organic anions [112]. 

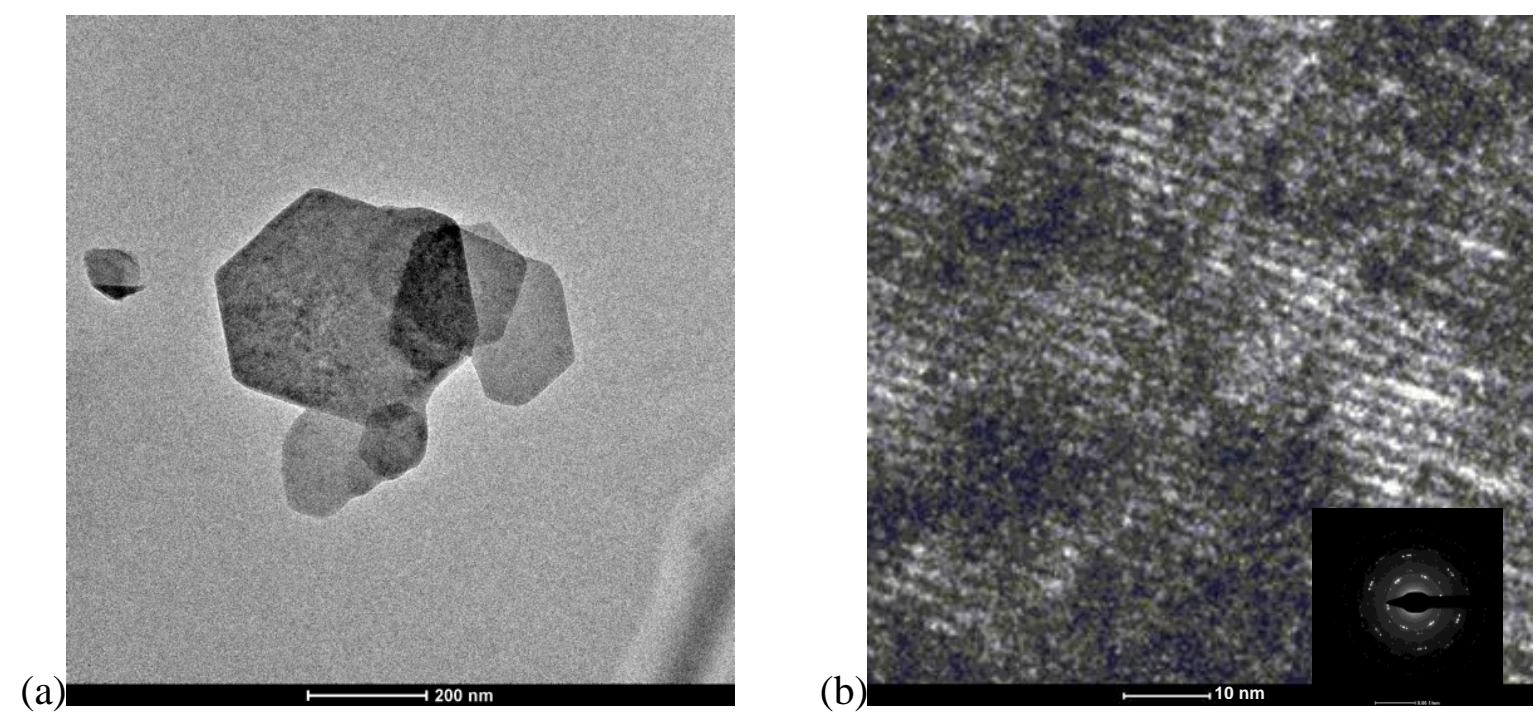

Figure 18 Bright-field (a) and dark-field (b) TEM images of CaFe-LDH.

The distance between two layers was estimated from a transmission electron microscopic dark-field image (Figure $18(\boldsymbol{b})$ ) giving a value of approximately $0.58 \mathrm{~nm}$. If one subtracts this from the basal spacing $(0.77 \mathrm{~nm})$ obtained from powder XRD, the layer thickness value is $0.19 \mathrm{~nm}$, which is in good agreement with the $0.178 \mathrm{~nm}$, determined by others from high-precision XRD data [7].

\subsection{The dehydration-rehydration characteristics of the CaFe-LDH samples}

It is known that an air-dried, as-prepared LDH contains water molecules in various forms. The TG measurements revealed three distinctive forms (Figure 19). Physisorbed and interlayer water molecules were removed in the $375-425 \mathrm{~K}$ and $450-600 \mathrm{~K}$ temperature ranges, respectively. Water from the dehydration of structural $\mathrm{OH}$ groups and water molecules closely associated (through hydrogen bonding) to the layers departed from $650 \mathrm{~K}$ to $725 \mathrm{~K}$. This high-temperature form will be called 'structural water' in the followings. Even though it exists in the form of $\mathrm{OH}$ groups in the layer, it is released as water upon dehydration. On further raising the temperature, complete structural collapse took place, and at high enough temperature recrystallization to a 3D structure started. It is to be observed that none of the DTG peaks are sharp, indicating that the water molecules are not uniform in energy even within the groups. Physisorption occurs on the outer surface of the LDH, which is energetically heterogeneous, and the molecules are adsorbed in multilayers. The interlayer water molecules are not uniform either, as far as their bonding energies are concerned. There is more than one water layer in the interlayer spacing, and molecules sitting closer to the 
charged layers are bound more strongly than those situated farther away. Likewise, there is bonding energy distribution for the structural water molecules, too.

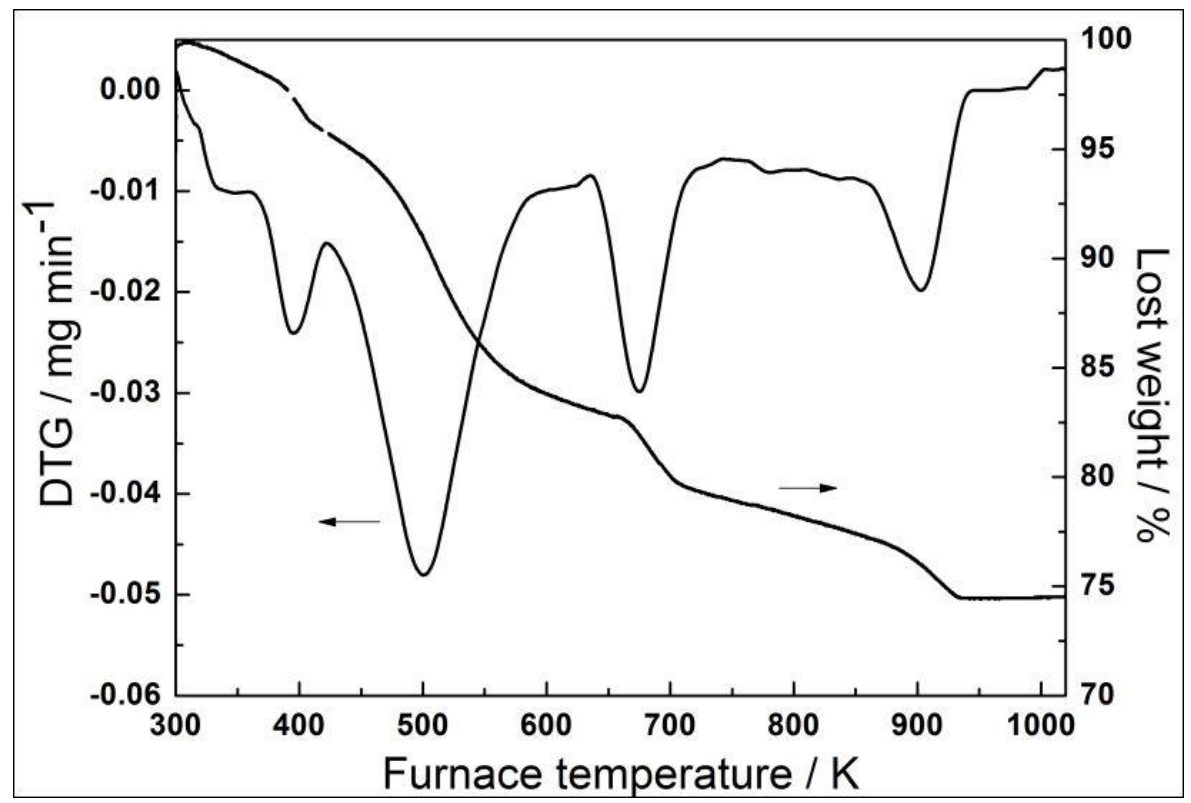

Figure 19 TG/DTG curves for CaFe LDH.

It has been shown that the LDH sample loses its layered structure on heat treatment; however, if the temperature does not exceed $773 \mathrm{~K}$, it regains the original lamellar structure completely (Figure 20) under rehydration conditions (stirring in water for $24 \mathrm{~h}$, then filtering and drying in air).

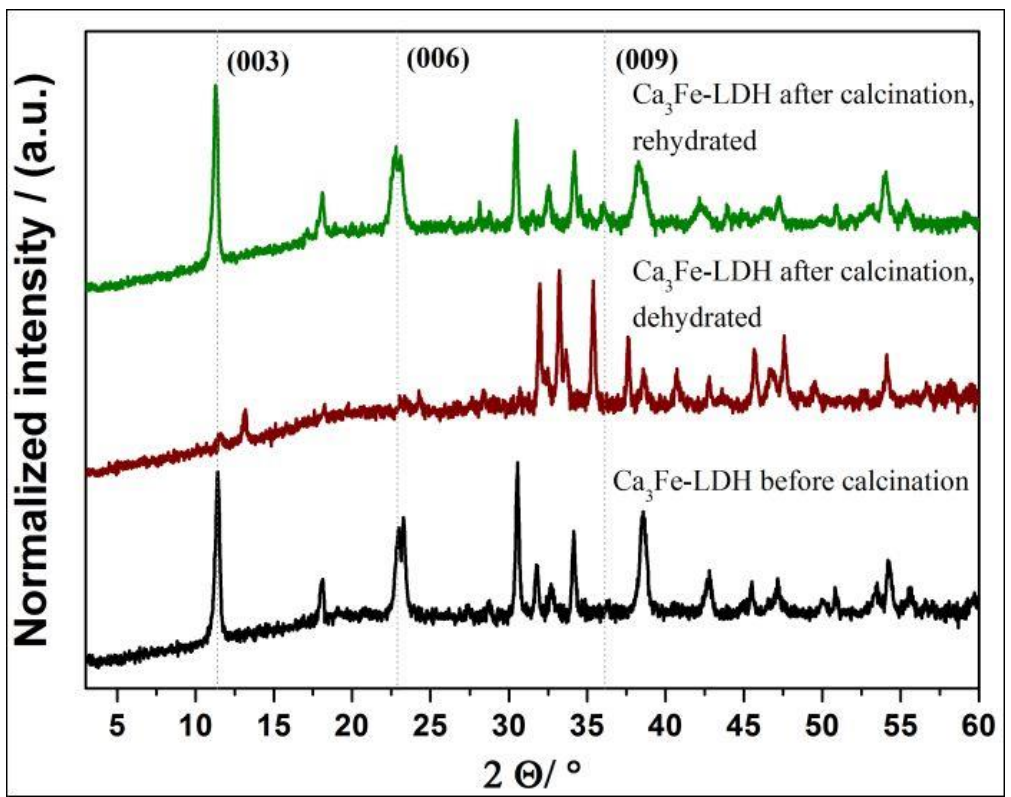

Figure 20 Dehydration (at $773 \mathrm{~K}$ under $N_{2}$ ) and rehydration (in ethanol/water solution) of the CaFe-LDH. 
For the more detailed investigation of the dehydration/rehydration processes, both processes were examined by XRD and Mössbauer spectroscopy, following treatments at various temperatures and by the DRS method after partial rehydration in environments with controlled relative humidities. 

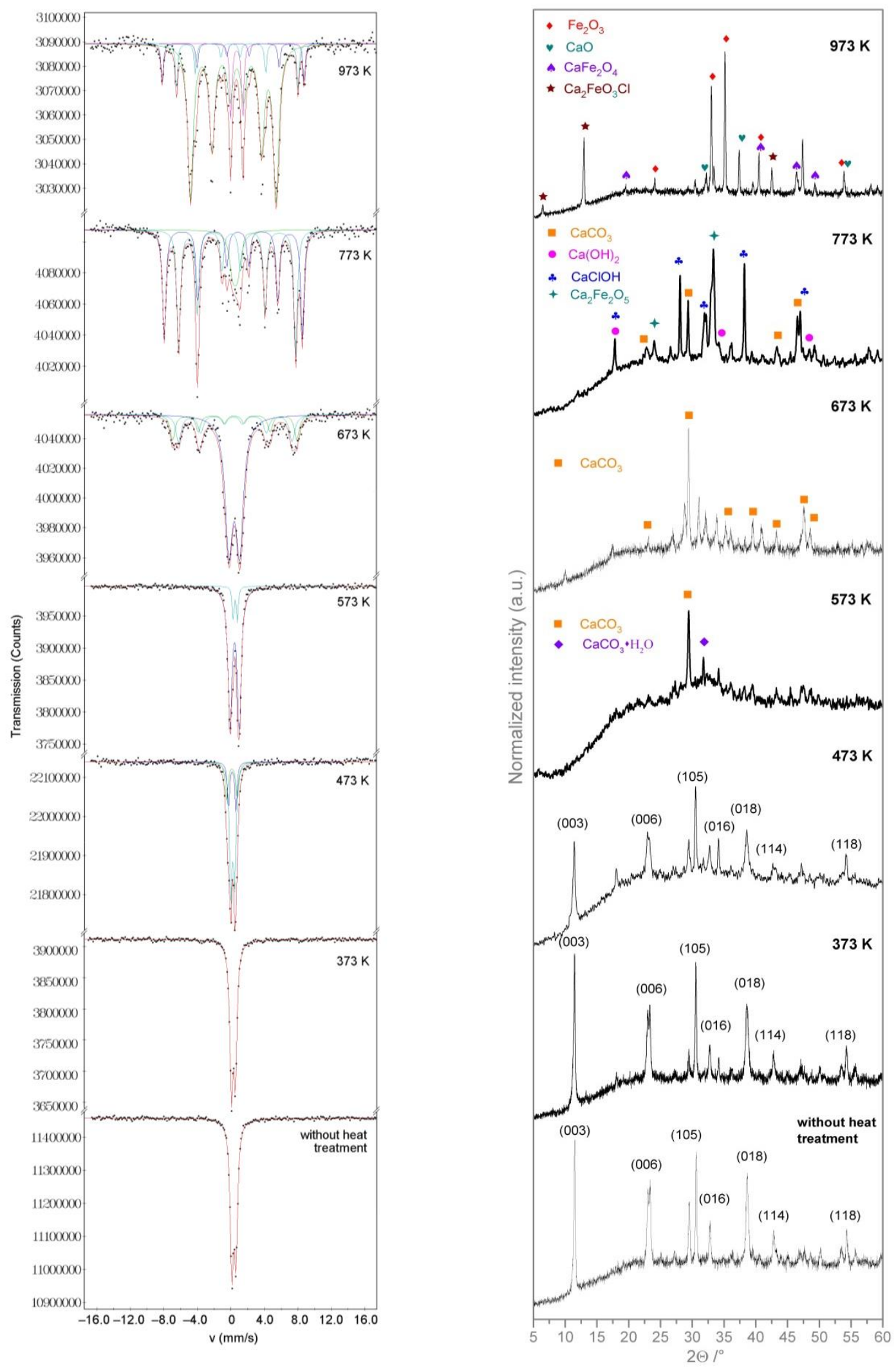

Figure $21{ }^{57} \mathrm{Fe}$ Mössbauer spectra and the corresponding X-ray diffractograms of the heattreated CaFe-LDH sample (heat treatments were performed at temperatures indicated on the graphs for $5 \mathrm{~h}$ ). 
The ${ }^{57} \mathrm{Fe}$ Mössbauer spectrum of the pristine CaFe-LDH can be described with an asymmetric doublet as has been described in a previous study by our research group [109]. The spectrum indicates that the iron content is incorporated in the LDH phase in full.

Heat treatment at $373 \mathrm{~K}$ results in no significant changes either in the X-ray diffractogram or the Mössbauer parameters, indicating that the layered structure remains intact after heat treatment at this temperature.

In the XRD pattern of the sample annealed at $473 \mathrm{~K}$, there is significant decrease in the relative intensities of the lines corresponding to the $\mathrm{LDH}$ structure. Nevertheless, it is still the predominant phase. However, the precipitation of other hydroxide phases is possible, since the Mössbauer spectrum clearly shows that the Fe(III) ions are present in at least two different microenvironments in addition to the $\mathrm{LDH}$, i.e., the destruction of layered double hydroxide is on the way.

After heat treatment at $573 \mathrm{~K}$, the LDH phase disappears nearly completely. The crystallinity of the sample is largely lost, as only a small amount of secondary crystalline phases is observed [calcite $\left(\mathrm{CaCO}_{3}\right)$ and monohydrocalcite $\left.\left(\mathrm{CaCO}_{3} \cdot \mathrm{H}_{2} \mathrm{O}\right)\right]$. The iron(III) content is incorporated in the amorphous phase, which is the predominant structural feature. Here, the Fe(III) ions are in a microenvironment similar to that of iron(III) hydroxide as the ${ }^{57} \mathrm{Fe}$ Mössbauer spectrum attests (Table 2).

Further increase in temperature (heat treatment at $673 \mathrm{~K}$ and up) results in the narrowing of the broad reflections, indicating the formation of new crystalline phases.

The diffractogram of the sample heat treated at $673 \mathrm{~K}$ contains many sharp peaks compared to the previous one, although the predominant crystalline phase is still the calcium carbonate, indicated by the X-ray diffractogram. On the basis of the ${ }^{57} \mathrm{Fe}$ Mössbauer spectrum, the amorphous phase may be $\mathrm{Ca}_{3} \mathrm{Fe}_{2} \mathrm{O}_{6}$ with a structure similar to tricalcium aluminate. Calcium- and aluminium-containing layered double hydroxides at elevated temperature in alkaline medium can be transformed to tricalcium aluminate, and generally, the aluminium is easily replaced by iron(III) ions. The existence of $\mathrm{Ca}_{3}(\mathrm{Al}, \mathrm{Fe})_{2} \mathrm{O}_{6}$ compound has been proven [113,] and the ${ }^{57} \mathrm{Fe}$ Mössbauer spectra is in good agreement with this. It can be interpreted as a doublet, representing the predominant iron-containing amorphous phase, and sextets implying the formation of the tricalcium-iron oxide.

The diffractogram measured after heat treatment at $773 \mathrm{~K}$ indicates that multiple phases are present. Iron forms a mixed oxide with calcium with a molecular formula of $\mathrm{Ca}_{2} \mathrm{Fe}_{2} \mathrm{O}_{5}$. Calcium is present in several forms in addition to the previous mixed oxide, like calcium hydroxide, calcium chloride-hydroxide and calcium carbonate. $\mathrm{The}^{-} \mathrm{Cl}^{-}$ions, formerly located 
between the layers derived from the stock metal salts, replace a portion of the hydroxide ions, and this leads to the formation of calcium chloride-hydroxide. The orthorhombic $\mathrm{Ca}_{2} \mathrm{Fe}_{2} \mathrm{O}_{5}$ known as srebrodolskite, forms a series with brownmillerite, and its presence is explicitly confirmed by the Mössbauer parameters [114]. In addition, the presence of small amounts of secondary phases, such as, e.g., $\mathrm{CaFe}_{4} \mathrm{O}_{6}$, is very likely. The ${ }^{57} \mathrm{Fe}$ Mössbauer spectra also reveal the formation of the corresponding calcium-iron oxide inverse spinel phase, which represents about $5 \%$ of the paramagnetic state, even at the temperature of liquid nitrogen.

On further increasing the temperature of heat treatment to $973 \mathrm{~K}$, a new set of peaks appears in the X-ray diffractogram, showing the development of new structures. Here, the sharp lines correspond primarily to the well-crystallised $\mathrm{Ca}_{2} \mathrm{FeO}_{4}$ spinel, but the presence of other compositions (e.g., $\mathrm{Ca}_{2} \mathrm{Fe}_{2} \mathrm{O}_{5}$ ) can also be detected [115, 116]. Furthermore, the proportion of each spinel phase can be deduced from the ${ }^{57} \mathrm{Fe}$ Mössbauer spectra. Thus, the compositions and the crystal structures formed are substantially different from the previous ones. 
Table $2{ }^{57} \mathrm{Fe}$ Mössbauer parameters at $78 \mathrm{~K}$ for the CaFe-LDH samples heat treated at various temperatures.

\begin{tabular}{|c|c|c|c|c|c|c|}
\hline & & $A_{d}$ & $\begin{array}{c}\delta \\
\left(\mathrm{mms}^{-1}\right)\end{array}$ & $\begin{array}{c}\Delta \\
\left(\mathrm{mms}^{-1}\right)\end{array}$ & $\begin{array}{c}\mathrm{W} \\
\left(\mathrm{mms}^{-1}\right)\end{array}$ & $\mathrm{T}$ \\
\hline $\mathrm{Fe}(\mathrm{OH})_{3}$ & doublet (1) & $100.0 \%$ & 0.356 & 0.777 & 0.500 & \\
\hline CaFe-LDH & doublet (1) & $100.0 \%$ & 0.366 & 0.490 & 0.468 & \\
\hline \multicolumn{7}{|l|}{$\begin{array}{l}\text { Temperature of } \\
\text { heat treatment }\end{array}$} \\
\hline \multirow{4}{*}{$473 \mathrm{~K}$} & doublet (1) & $100.0 \%$ & 0.369 & 0.474 & 0.444 & \\
\hline & doublet (1) & $59.0 \%$ & 0.345 & 0.450 & 0.358 & \\
\hline & doublet (2) & $21.0 \%$ & 0.252 & 1.260 & 0.413 & \\
\hline & doublet (3) & $20.0 \%$ & 0.278 & 0.882 & 0.294 & \\
\hline \multirow{2}{*}{$573 \mathrm{~K}$} & doublet (1) & $90.1 \%$ & 0.239 & 1.071 & 0.529 & \\
\hline & doublet (2) & $9.9 \%$ & 0.310 & 0.480 & 0.237 & \\
\hline \multirow{3}{*}{$673 \mathrm{~K}$} & doublet (1) & $64.1 \%$ & 0.203 & 1.241 & 1.046 & \\
\hline & sextet (1) & $16.3 \%$ & 0.222 & 0.063 & 0.663 & 44.683 \\
\hline & sextet (2) & $19.6 \%$ & 0.217 & 0.208 & 0.751 & 40.810 \\
\hline \multirow{3}{*}{$773 \mathrm{~K}$} & doublet (1) & $13.9 \%$ & 0.303 & 0.547 & 0.928 & \\
\hline & sextet (1) & $40.0 \%$ & 0.345 & -0.522 & 0.456 & 49.57 \\
\hline & sextet (2) & $46.1 \%$ & 0.182 & 0.695 & 0.456 & 42.01 \\
\hline \multirow{4}{*}{$973 \mathrm{~K}$} & doublet (1) & $7.7 \%$ & 0.490 & 1.365 & 0.307 & \\
\hline & sextet (1) & $75.5 \%$ & 0.286 & -0.414 & 0.766 & 30.69 \\
\hline & sextet (2) & $9.0 \%$ & 0.147 & 0.774 & 0.301 & 43.60 \\
\hline & sextet (3) & $7.8 \%$ & 0.351 & -0.558 & 0.301 & 50.90 \\
\hline
\end{tabular}

From these data, it is readily noticeable that the increasing temperature of heat treatment has significant effect on the structure of CaFe-LDH. Radical changes occur, the LDH phase transforms to a large variety of crystalline materials via an amorphous phase.

It is generally believed - and, as it has been shown, it coincides with our own experience as well - that heat treatment at $773 \mathrm{~K}$ results in complete dehydration and in the collapse of the layered structure. However, in water or in a humid environment the process is reversible. Rehydration was studied in detail on CaFe-LDH dehydrated at $773 \mathrm{~K}$. Samples of the dehydrated material were equilibrated under preset humidity values for 72 hours at 
ambient temperature. The resulting structures were studied by thermogravimetry, X-ray diffractometry, FT-IR spectroscopy, and the dielectric relaxation spectra were also recorded and analysed.

Data, deduced from the thermogravimetric profiles of the partially rehydrated samples, are summarised in Table 3.

Table 3 Weight losses (in \%) during heat treatment of partially rehydrated CaFe-LDH samples.

\begin{tabular}{lcccccccccc}
\hline \multirow{2}{*}{ water type } & \multicolumn{10}{c}{ Relative Humidity (\%) } \\
\cline { 2 - 11 } & 6 & 11 & 22 & 29 & 33 & 43 & 53 & 62 & 75 & 84 \\
\hline interlayer/\% & 0 & 0 & 0.23 & 0.45 & 0.95 & 2.67 & 3.56 & 2.11 & 5.26 & 3.69 \\
structural/\% & $\begin{array}{c}\text { very } \\
\text { small }\end{array}$ & 0.41 & 2.15 & 2.02 & 2.53 & 2.45 & 0.56 & 2.12 & 1.49 & 2.58 \\
\hline
\end{tabular}

At low relative humidity $(\mathrm{RH}=6 \%$ ), beside physisorbed water molecules, structural water was also found in a very small amount, indicating that the rehydration of the layer has already started. At this point, interlayer water was not seen at all. At $\mathrm{RH}=22 \%$ interlayer water appeared. Its relative quantity grew with the increase in RH values and soon it overtook that of structural water, which went to near saturation at $\mathrm{RH}=33-43 \%$.

The XRD traces for the partially rehydrated samples are displayed in Figure 22.

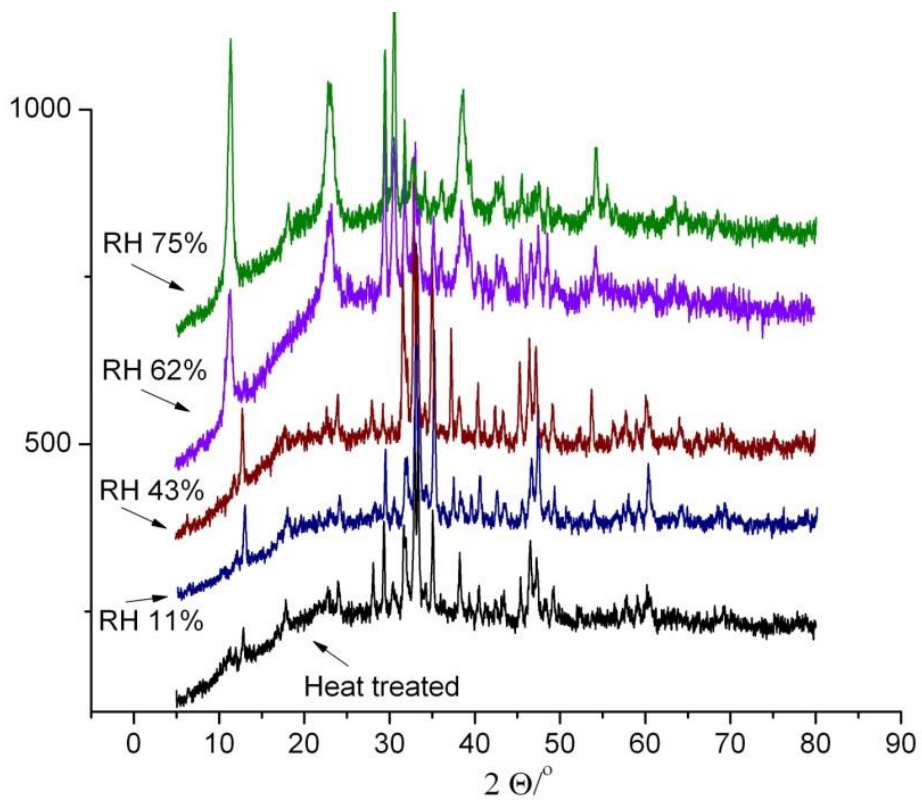

Figure 22 Powder X-ray diffractograms of selected partially rehydrated CaFe-LDH samples, rehydrated at various relative humidity values. 
It is to be seen that already at low relative humidity $(\mathrm{RH}=11 \%)$, the reconstruction of the LDH structure has started. During reconstruction, the dehydrated layer was rehydrated first (structural water was regained). Then interlayer water appeared among the layers resulting in the shift of the (003) reflection towards lower $2 \Theta$ values, and the reappearance of the layered structure was almost complete by $\mathrm{RH}=75 \%$. Steps of this sequence overlap in an increasing manner with the increase of relative humidity.

To confirm the structural changes occurring at different relative humidity values for the Fe(III) ions, ${ }^{57} \mathrm{Fe}$ Mössbauer spectra were analysed. Their evaluation at $78 \mathrm{~K}$ was optimal when fitting an asymmetric doublet or two sextets for the different rehydration states of thermally decomposed LDH.
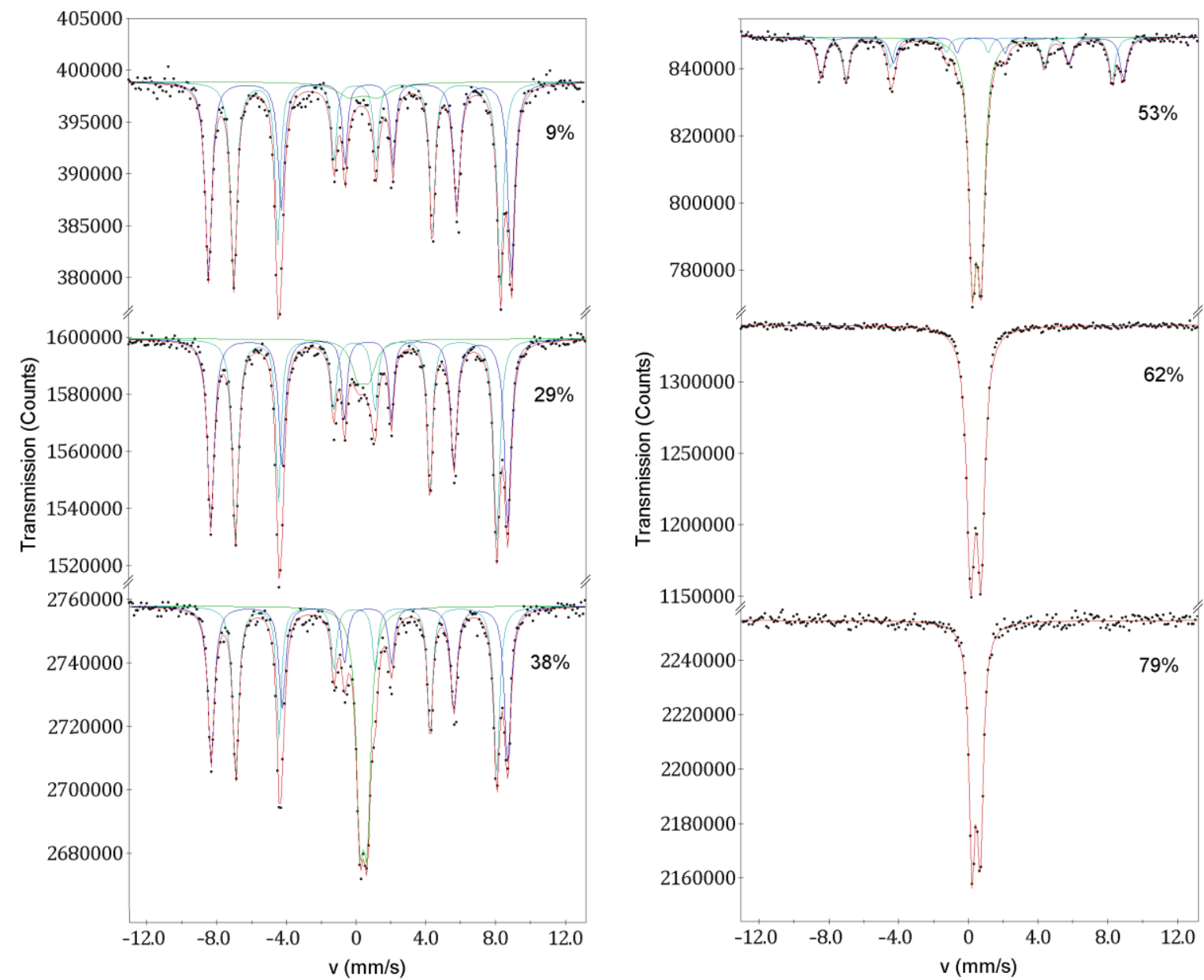

Figure 23 Evolution of the ${ }^{57} \mathrm{Fe}$ Mössbauer spectra of the dehydrated LDH at different relative humidity values during the hydration cycle.

The ${ }^{57} \mathrm{Fe}$ Mössbauer parameters of the samples measured at $78 \mathrm{~K}$ are listed in Table 4. Doublet parameters, found for the sample rehydrated at $78 \%$ relative humidity, correspond to 
the as-prepared CaFe-LDH sample. However, the parameters of the two sextets measured at rehydrating conditions of $9 \%$ relative humidity value can be designated to a brownmilleritelike phase.

Table 4 The relative abundance of the doublet and sextet components of Mössbauer spectra.

\begin{tabular}{llllll}
\hline \multirow{2}{*}{$\begin{array}{l}\text { Relative } \\
\text { humidity }\end{array}$} & \multirow{2}{*}{$\begin{array}{l}\text { sextet(s) } \\
\mathrm{A}_{\mathrm{s}}\end{array}$} & \multicolumn{3}{c}{ Doublet } \\
\cline { 3 - 6 } & & $\mathrm{A}_{\mathrm{d}}$ & $\delta\left(\mathrm{mms}^{-1}\right)$ & $\Delta\left(\mathrm{mms}^{-1}\right)$ & $\mathrm{W}\left(\mathrm{mms}^{-1}\right)$ \\
\hline $9 \%$ & $98 \%$ & $2 \%$ & 0.42 & 1.62 & 1.77 \\
$29 \%$ & $91 \%$ & $9 \%$ & 0.44 & 0.63 & 0.91 \\
$38 \%$ & $73 \%$ & $27 \%$ & 0.43 & 0.41 & 0.51 \\
$53 \%$ & $42 \%$ & $58 \%$ & 0.44 & 0.48 & 0.49 \\
$62 \%$ & $0 \%$ & $100 \%$ & 0.44 & 0.59 & 0.52 \\
$79 \%$ & $0 \%$ & $100 \%$ & 0.44 & 0.47 & 0.42 \\
\hline
\end{tabular}

The ${ }^{57} \mathrm{Fe}$ Mössbauer spectra indicate the monotonous increase in the relative areas of doublets, and at the same time a monotonous decrease in the relative areas of the sextets in the function of the relative humidity values. This may be related to the LDH - brownmillerite transformation at $773 \mathrm{~K}$, which may be determined by the relative humidity. This also corresponds to the previous measurement for the heat-treated (at $773 \mathrm{~K}$ ) sample, which shows magnetic splitting at room temperature, whereas the corresponding spectrum of rehydrated sample is a doublet. The isomeric shifts $(0.42-44 \mathrm{~mm} / \mathrm{s})$ are typical for octahedrally coordinated Fe(III) [117], the large value of the quadrupole splitting $(0.47$ to $0.63 \mathrm{~mm} / \mathrm{s})$ has to be explained by a non-symmetrical environment around the $\mathrm{Fe}(\mathrm{III})$ ions, i.e., by the presence of distorted $\mathrm{Fe}(\mathrm{OH})_{6}$ octahedra at both sites. At $9 \%$ relative humidity both the quadrupole splitting and the line width are significantly different from those measured at higher values. This is consistent with the XRD results, as after annealing at $773 \mathrm{~K}$, there is a high degree of disorder due to the disintegration of the layers. Here, the sextet also shows an inhomogeneous image, it is a characteristic of the magnetic distribution. This implies that a small amount of $\mathrm{Fe}_{2} \mathrm{O}_{3}$ may be present in the sample. At higher relative humidity values, the ${ }^{57} \mathrm{Fe}$ Mössbauer parameters of the heat-treated samples coincide with those of the freshly prepared sample, indicating that in the rebuilt structures, the microenvironment of iron is approximately the same as in the original $\mathrm{CaFe}-\mathrm{LDH}$. This is possible through the dissolution and re-precipitation of the solid phases, resulting in the layered double hydroxide. The 
mechanism of dissolution of mixed oxides and subsequent crystallisation of layered double hydroxides [118] explains the formation of LDH with new anions well, and implies a possibility of changing the cation positions during the regeneration process.

The X-ray diffractogram of the sample heat treated at $773 \mathrm{~K}$, and then, rehydrated in liquid water clearly shows the hexagonal structure typical of the original LDHs. The ${ }^{57} \mathrm{Fe}$ Mössbauer spectrum also supports this conclusion. Thus, the rehydration results in a transformation of the spinel-like structure into a hexagonal structure. This phenomenon is particularly conspicuous, whereas for the sample heat-treated at $773 \mathrm{~K}$, the ${ }^{57} \mathrm{Fe}$ Mössbauer spectrum showed considerable magnetic splitting, while the corresponding spectrum of the rehydrated sample was a doublet. This observation is in good coincidence with the results of rehydration experiments at various relative humidity values.

The FT-IR spectra of the partially rehydrated samples (Figure 24) give hints on the sequence of the rehydration steps. The sample rehydrated at $\mathrm{RH}=11 \%$ displays a peak (Figure 24 trace coloured black) at $3643 \mathrm{~cm}^{-1}$ that can be assigned to isolated $\mathrm{OH}$ groups. This is structural $\mathrm{OH}$, observable because the relative humidity is low and either there is not enough water present or the rehydration of the layers is not fast enough to form a hydrogenbonded OH network exclusively. At higher RH values (Figure 24, traces coloured red and green), only the broad bands above $3000 \mathrm{~cm}^{-1}$ are observed, i.e., a hydrogen-bonded $\mathrm{OH}$ network was formed. Although this network consists of structural $\mathrm{OH}$ groups, physisorbed water also contributes to it, probably even at the lowest RH value. Also at the lowest RH value, one finds a peak around $1620 \mathrm{~cm}^{-1}$, gaining intensity as the RH value grow. This band is assigned to the deformation vibration of the interlayer water molecules. (The bands under $1000 \mathrm{~cm}^{-1}$ may be assigned to the $\mathrm{O}-$ metal ion- $\mathrm{O}$ units of the layers [119]). 


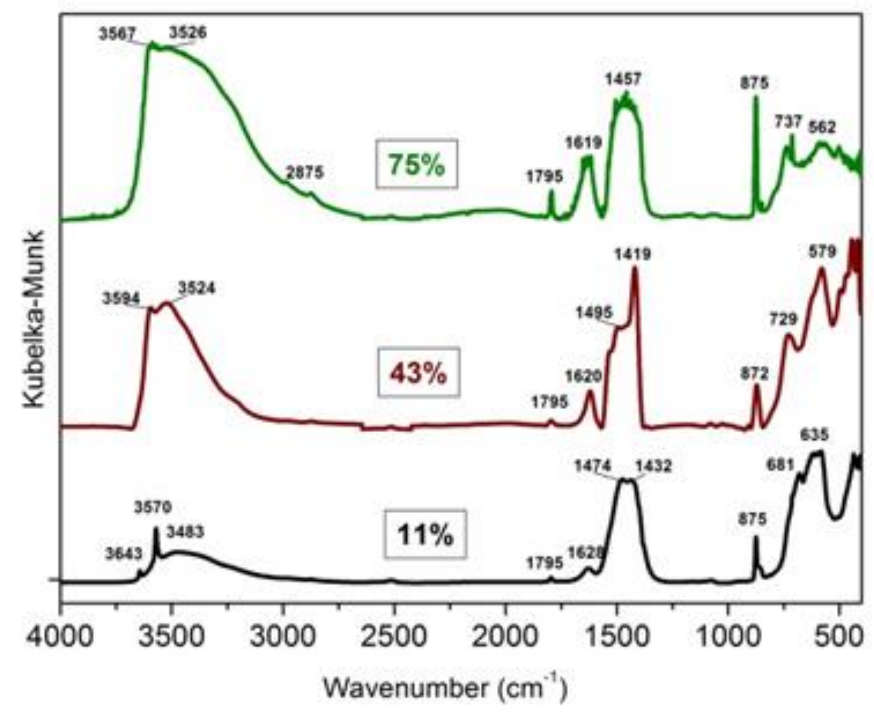

Figure 24 FT-IR spectra of the heat-treated CaFe-LDH samples rehydrated at 11\%, 43\% and $75 \%$ relative humidity $(\mathrm{RH} \%)$ values.

\subsubsection{Dehydration and rehydration monitored by dielectric relaxation spectroscopy}

The dehydrated samples, equilibrated at various RH values, were studied by DRS measurements.

The LDH powder may be regarded as a heterogeneous system, in which various water types are present at different positions and interfaces. The dielectric properties of these different positions and interfaces are reflected in the DRS spectrum. Thus, the gradual rehydration of the dehydrated LDH can be followed by this type of spectroscopy. These properties are characterised by the complex dielectric function

$$
\varepsilon *(\omega)=\varepsilon^{\prime}(\omega)-i \varepsilon^{\prime \prime}(\omega)
$$

where $\varepsilon^{\prime}(\omega)$ is the real and $\varepsilon^{\prime \prime}(\omega)$ is the imaginary part and $\omega=2 \pi f$.

Although the $\varepsilon^{*} v s . \omega$ function gives an impressive (quasi) 3D picture, for the sake of simplicity, either the $\varepsilon^{\prime}(\omega)$ or the $\varepsilon^{\prime \prime}(\omega)$ functions are depicted.

The room-temperature DRS spectra of the originally completely dehydrated CaFe-LDH samples, after being kept under controlled humidity until equilibrium is reached, are displayed in Figure 25. In the figure, variations in the imaginary part $\left(\varepsilon^{\prime \prime}\right)$ of the dielectric function $v s$. frequency are shown, as they are more spectacular than the real part. It is to be noted that in both representations, the dielectric function varied systematically with the changing humidity. 


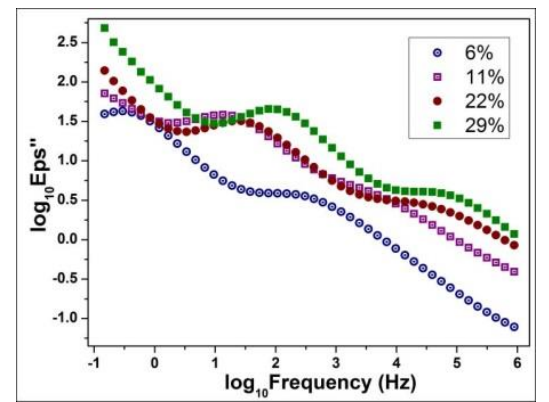

(a)

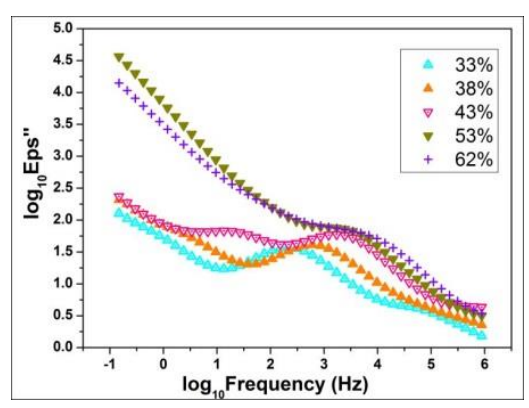

(b)

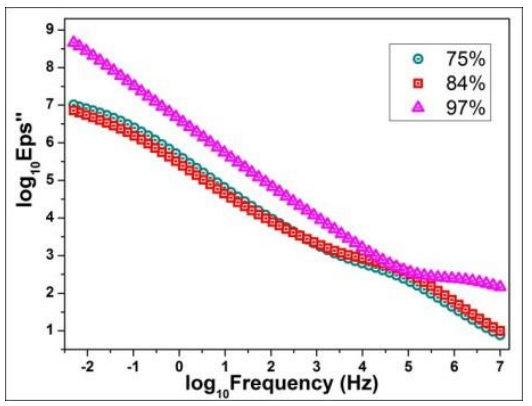

(c)

Figure 25 Raw permittivity vs. frequency data (imaginary part is depicted) for $\mathrm{Ca}_{3} \mathrm{Fe}-\mathrm{LDHS}$ equilibrated under various relative humidity values of (a) $6 \%, 11 \% 22 \%, 29 \%$, (b) $33 \%, 38 \%$, $43 \%, 53 \%, 62 \%$, (c) $75 \%, 84 \%, 97 \%$.

The spectra shown in Figure 25 can be divided into two groups. In the first one (at RH $=6 \%-62 \%$ - Figure $25(\boldsymbol{a})$ and $(\boldsymbol{b}))$ three distinct relaxation processes can be identified, while at RH $=75 \%-97 \%$ Figure $25(\boldsymbol{c}))$, the conduction part and the electrode polarisation (EP) become predominant. Thus, unfortunately, relaxation times cannot be extracted from the data sets displayed in Figure 25 (c), and these data cannot reliably be used for describing the rehydration procedure.

In order to be able to quantitatively describe the water-uptake processes and give as accurate relaxation times $(\tau)$ related to the positions and interfaces involving the three water types as possible, the most complicated model, the Havriliak-Negami parametrised Debye equation was fitted together with the conductivity and the electrode polarisation terms [120, 121]:

$$
\varepsilon *(\omega)=\varepsilon_{\infty}+\sum_{i=1}^{4} \frac{\Delta \varepsilon_{i}}{\left(1+\left(i \omega \tau_{i}\right)^{\alpha}\right)^{\beta}}-i a\left(\frac{\sigma_{d c}}{\varepsilon_{0} \omega^{S}}\right)+\frac{A}{\omega^{S}}
$$

where $\omega=2 \pi \mathrm{f}, \varepsilon^{*}$ is the complex dielectric function, $\Delta \varepsilon=\varepsilon_{s}-\varepsilon_{\infty}$ is the dielectric strength, $\varepsilon_{\mathrm{s}}$ and $\varepsilon_{\infty}$ is the dielectric constant at very low and at very high frequencies, respectively, $\varepsilon_{0}=8.8542 \cdot 10^{-12} \mathrm{~F} / \mathrm{m}$ is the permittivity of vacuum, $\tau$ is the relaxation time, $\alpha, \beta$ are fitting parameters characterising peak broadening, $\sigma_{0}$ is the specific conductivity. $\mathrm{S} \leq 1$ determines the slope of the conductivity tail in double logarithm formalism, the factor $\mathrm{A}$ has the dimension of $(\mathrm{rad} \cdot \mathrm{Hz}) \mathrm{s} / \mathrm{Hz}$, and $0 \leq \mathrm{A}$ is the magnitude of $\mathrm{EP}$. During the fitting procedure, the $\beta$ parameter was always found to be close to 1 . Thus, the relaxation equation used is reduced to the simpler Cole-Cole function [122]. 
Since strong conductivity and EP mask the dielectric processes in an increasing extent with the increase of the relative humidity, the relaxation processes are much better seen if a derived formalism, i.e., the complex electric modulus formalism, defined as

$M^{*}(\omega)=M^{\prime}(\omega)+i M^{\prime \prime}(\omega)=\frac{1}{\varepsilon *(\omega)}=\frac{\varepsilon^{\prime}(\omega)}{\varepsilon^{\prime}(\omega)^{2}+\varepsilon^{\prime \prime}(\omega)^{2}}+i \frac{\varepsilon^{\prime \prime}(\omega)}{\varepsilon^{\prime}(\omega)^{2}+\varepsilon^{\prime \prime}(\omega)^{2}}$

is used. The reason is that the square of the real and imaginary parts of permittivity are in the denominator of both components in the modulus function. The effect of the conduction and EP terms decreases, making a more robust evaluation possible in a broader humidity regime.

Both the real $\mathrm{M}^{\prime}(\omega)$, and the imaginary $\mathrm{M}^{\prime \prime}(\omega)$ parts of the modulus $v s$. frequency data set are displayed in Figure 26.

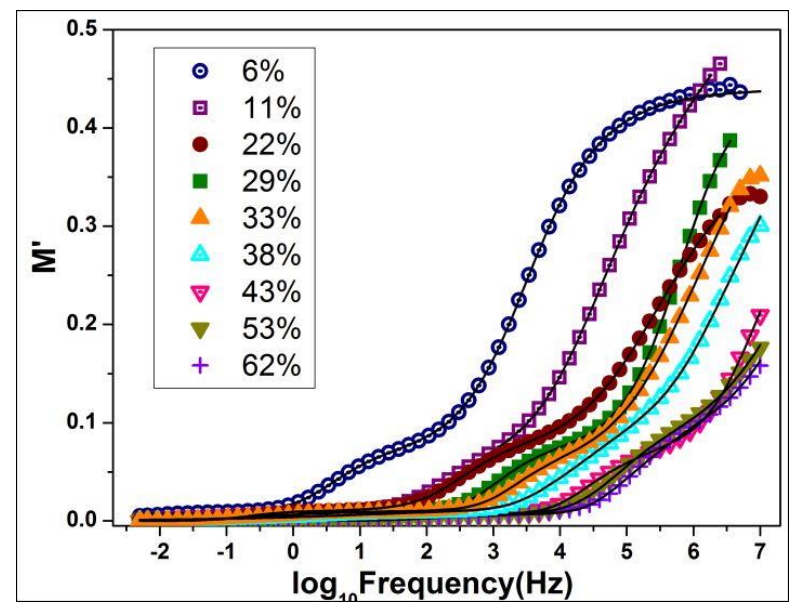

(a)

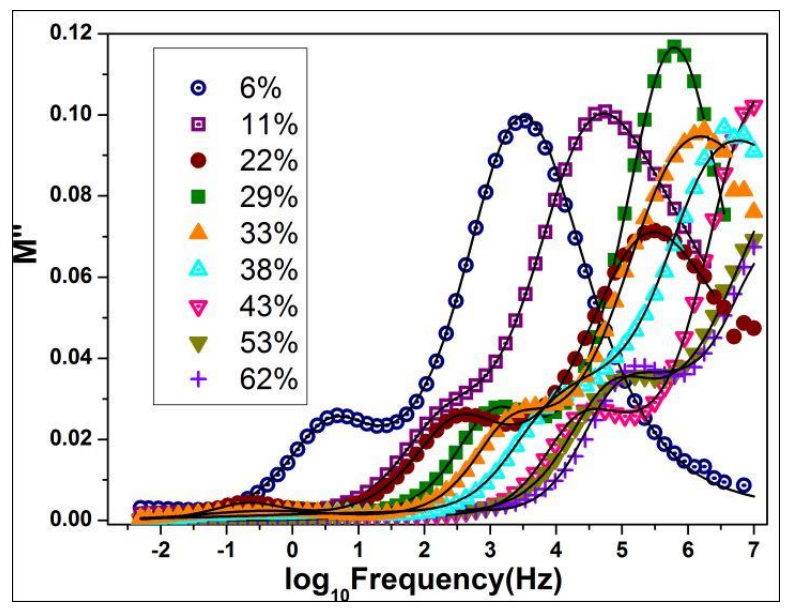

(b)

Figure 26 Electric modulus vs. frequency functions for $\mathrm{Ca}_{3} \mathrm{Fe}$-LDHs equilibrated under various relative humidity values, (a) real (b) imaginary parts, fitted with the Cole-Cole function.

The low-frequency relaxation in the spectra could be assigned to interfacial polarisation process (Maxwell-Wagner-Sillars or MWS process) caused by the accumulation of charges at the interfaces in the sample. Upon rehydration, the surface and subsurface oxides were gradually converted to hydroxides, and as the relative humidity values increased, the closely associated (hydrogen-bonded) water molecules were also regained. The maximum at $\sim 4.9 \mathrm{~Hz}$ $(\mathrm{RH}=6 \%)$ to $\sim 10^{5} \mathrm{~Hz}(\mathrm{RH}=62 \%)$ was assigned to this process [26]. As is seen, the maximum shifted towards higher frequencies with the increase in RH values. Concomitantly, interlayer water also appeared, giving rise to a peak at $\sim 3.5 \mathrm{kHz}(\mathrm{RH}=6 \%)$, which shifted to 
higher frequencies as the $\mathrm{RH}$ values increased [26]. At $\mathrm{RH}=38 \%$, it was found to be 3.67 $\mathrm{MHz}$, approaching the limit of the measuring range of our instrument. Relaxation of the most loosely bond water molecules (physisorbed water) would give peaks in $\mathrm{GHz}$ region, and it is clearly above the range of our measuring capability.

Let us show an even more detailed analysis for the sample partially rehydrated under $\mathrm{RH}=11 \%$ at room temperature, in which the decomposition of the various processes are shown (Figure 27). In the figure, the real and imaginary permittivities and the imaginary modulus spectra are depicted. At this temperature, three relaxations can be identified.

The full lines, obtained by fitting equation (8) or (9), show these relaxations separately. In the modulus formalism, the separated peaks are derived applying the following relationship: $M^{*}(\omega)=M_{\infty}+\frac{M_{s}-M_{\infty}}{1+(i \omega \tau M)^{\alpha}}$ with $M_{\infty}=\frac{1}{\varepsilon_{\infty}}$ and $M_{s=} \frac{1}{\varepsilon_{S}}[123]$.

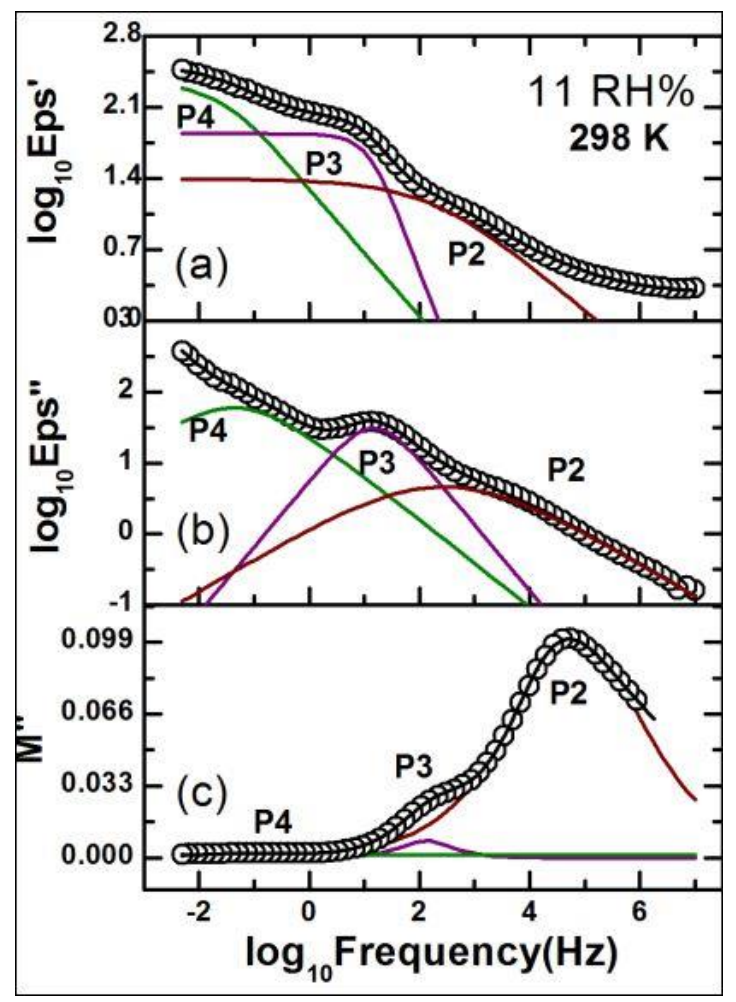

Figure 27 Permittivity vs. frequency data (top two graphs; upper: real part, lower: imaginary part) measured at $298 \mathrm{~K}$, and the derived dielectric modulus vs. frequency function (the bottom graph) for $\mathrm{Ca}_{3} \mathrm{Fe}$-LDH equilibrated at relative humidity value of $11 \%$.

The one at the lowest frequency was assigned to interfacial polarisation process ( $\mathrm{P} 4-$ MWS process) resulting from the accumulation of charges at the interfaces [124]. The maximum at $\sim 125 \mathrm{~Hz}$ was attributed to the rehydroxylation of the layers (P3), i.e., to the 
appearance structural $\mathrm{OH}$ groups [125]. Concomitantly, interlayer water also appeared (P2) giving rise to a peak at $\sim 63 \mathrm{kHz}$ [125]. The one, attributable to physisorbed water, has already, even at his low RH\% value, slipped out of our frequency window.

Complex nonlinear fitting was used for obtaining the relaxation times $(\tau)$ of the three processes. The relationship between water content and MWS relaxation is rather complex, and depends at least on the dielectric constant and the conductivity of the interface components, as well as the amount of water adsorbed [126, 127]. Upon rehydration, the structural water is regained first, and becomes tightly bound resulting in short relaxation time. It is longer for the more mobile interlayer water molecules. It would be even longer for the physisorbed water layer; unfortunately, a more sophisticated instrument would be needed for measuring those values.

The relaxation time data (obtained from the $\mathrm{M}^{*}$ ) vs. relative humidity (RH\%) functions for the three processes are seen in Figure 28.

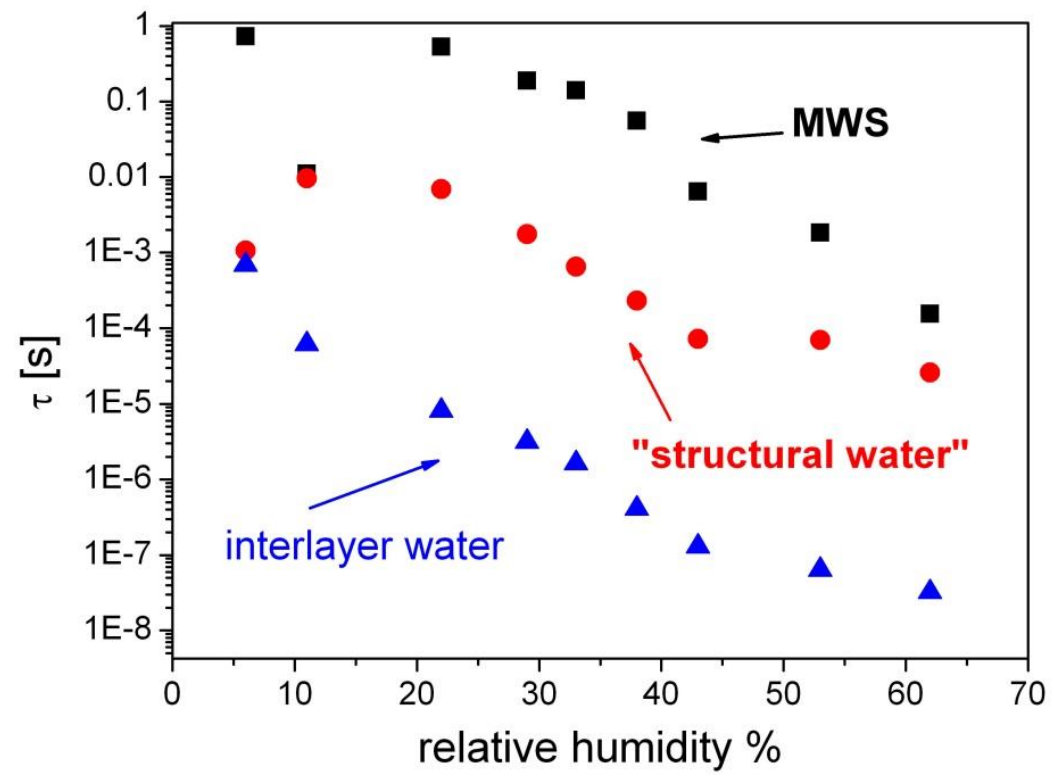

Figure 28 The relaxation time values obtained for the three processes observed by the DRS method during the partial rehydration of fully dehydrated $\mathrm{Ca} \mathrm{a}_{3} \mathrm{Fe}-\mathrm{LDH}$ samples at various humidity values (MWS: Maxwell-Wagner-Sillars polarisation).

In accordance with the expectation, the peaks in the $M "(\omega)$ spectrum shifted towards higher frequencies with increasing humidity, indicating that the relaxation time values decrease with increasing water content.

It can be seen, that if we want to identify and characterise each relaxation process even at higher RH values, the sample must be flash-cooled in order to freeze the actual hydration state of the LDH, and the DRS spectrum must be registered at that temperature. We have done exactly this: the samples were flash-cooled to $155 \mathrm{~K}$ (in a confined environment like our case, 
this can be done without the crystallisation of water [128]) and the DRS spectrum was registered. However, a further step was also taken, i.e., the samples were warmed up to $298 \mathrm{~K}$ in steps of $2.5 \mathrm{~K}$ and at each temperature, the dielectric relaxation spectra were registered. This means a rather large amount of data. If the plots were placed in stack, evaluation would be nearly impossible. Therefore, four-five representative spectra were chosen for display. The imaginary parts of the complex modulus vs. frequency functions are depicted, since changes are the most spectacular there.

Figure 29 displays the imaginary part of the dielectric modulus (M" $(\omega))$ as the function of frequency at $155 \mathrm{~K}$ for each sample.

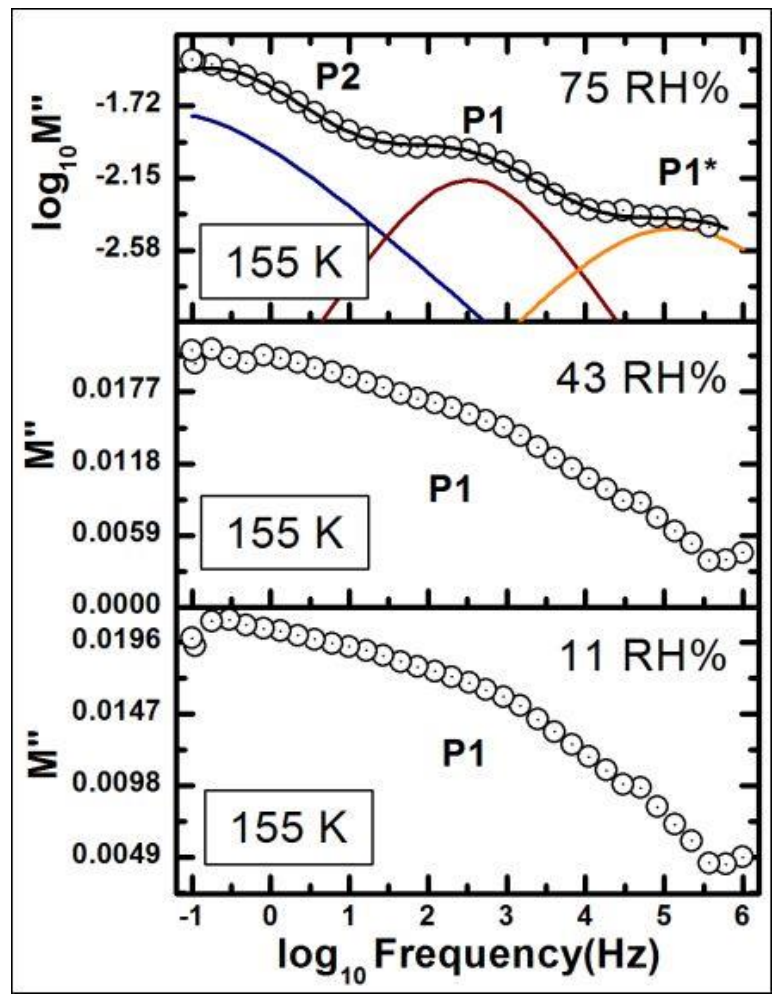

Figure 29 The imaginary parts of the dielectric modulus vs. frequency functions for the partially hydrated $(298 \mathrm{~K}$ ), then flash-cooled (to $155 \mathrm{~K}$ ) Ca3 Fe-LDH samples from measurements at $155 \mathrm{~K}$.

Now, for the samples prepared at the two low RH conditions, the relaxation of the physisorbed water (P1) appeared in the frequency window, indeed. However, those of the other water forms slipped out of it at the low-frequency end.

For the sample equilibrated under RH of $75 \%$ three relaxations could be observed. Two of them (P1 and $\left.\mathrm{P} 1^{*}\right)$ are related, they both belong to physisorbed water. P1 possibly corresponds to monolayer coverage and $\mathrm{P} 1 *$ to multilayers. Visually, at this high $\mathrm{RH}$ value the sample actually looks wet; thus, it is not surprising that multilayers of physisorbed water 
molecules sit on the outer surface. At this RH value, the relaxation attributable to interlayer water molecules also appears in our measuring range. However, the other two relaxation procedures are still out of it.

On the bases of information described here and in the previous section, the following picture on the rehydration process may be given. Even at the $\mathrm{RH}$ value of $11 \%$, when the availability of water molecules is relatively low, there is physisorbed water (DRS on the flashcooled sample) on the outer surface. This physisorbed water is probably not more than a monolayer. In the equilibrated sample, however, the layers are partially rehydroxylated (DRS at $298 \mathrm{~K}$ and the isolated $\mathrm{OH}$ band in the IR spectrum) and there is interlayer water as well (DRS at $298 \mathrm{~K}$ and $\mathrm{H}-\mathrm{O}-\mathrm{H}$ bending vibration in the IR spectrum). In the sample equilibrated at the medium RH value the rehydroxylation of the layers is probably completed (the isolated $\mathrm{OH}$ band disappeared from the IR spectrum), the quantity of the interlayer water content has increased (the intensity of the $\mathrm{H}-\mathrm{O}-\mathrm{H}$ bending vibration increased) and physisorbed water is present (probably a monolayer - DRS on the flash-cooled sample). The reconstruction of the layered structure is complete, when the rehydrated sample is equilibrated at the highest $\mathrm{RH}$ value, and the physisorbed water forms multilayer (DRS on the flash-cooled sample).

When the samples are gradually warmed up from $155 \mathrm{~K}$, the equilibria are broken and the water molecules are allowed to seek for energetically more favourable positions than they had at the lower temperature. Therefore, it may be possible to see some dynamics of the processes. Unfortunately, it is not going to be the full picture, because at increasing temperatures, the high-frequency processes gradually move and finally "leave" the frequency window available, while the low-frequency processes move into it. This means, for instance, that at increasing temperatures, relaxation(s) to be assigned to physically adsorbed water are going to slip out of the available frequency range. Of course, it does not necessarily mean that there is no physisorbed water at the higher temperature. Moreover, it is certain that there is physisorbed water at the medium and high RH samples, and it is very probable for the lowest RH sample as well.

In spite of the above-detailed limitations, it may be instructive to see the details on representative spectra at each RH (Figures 30-32). 


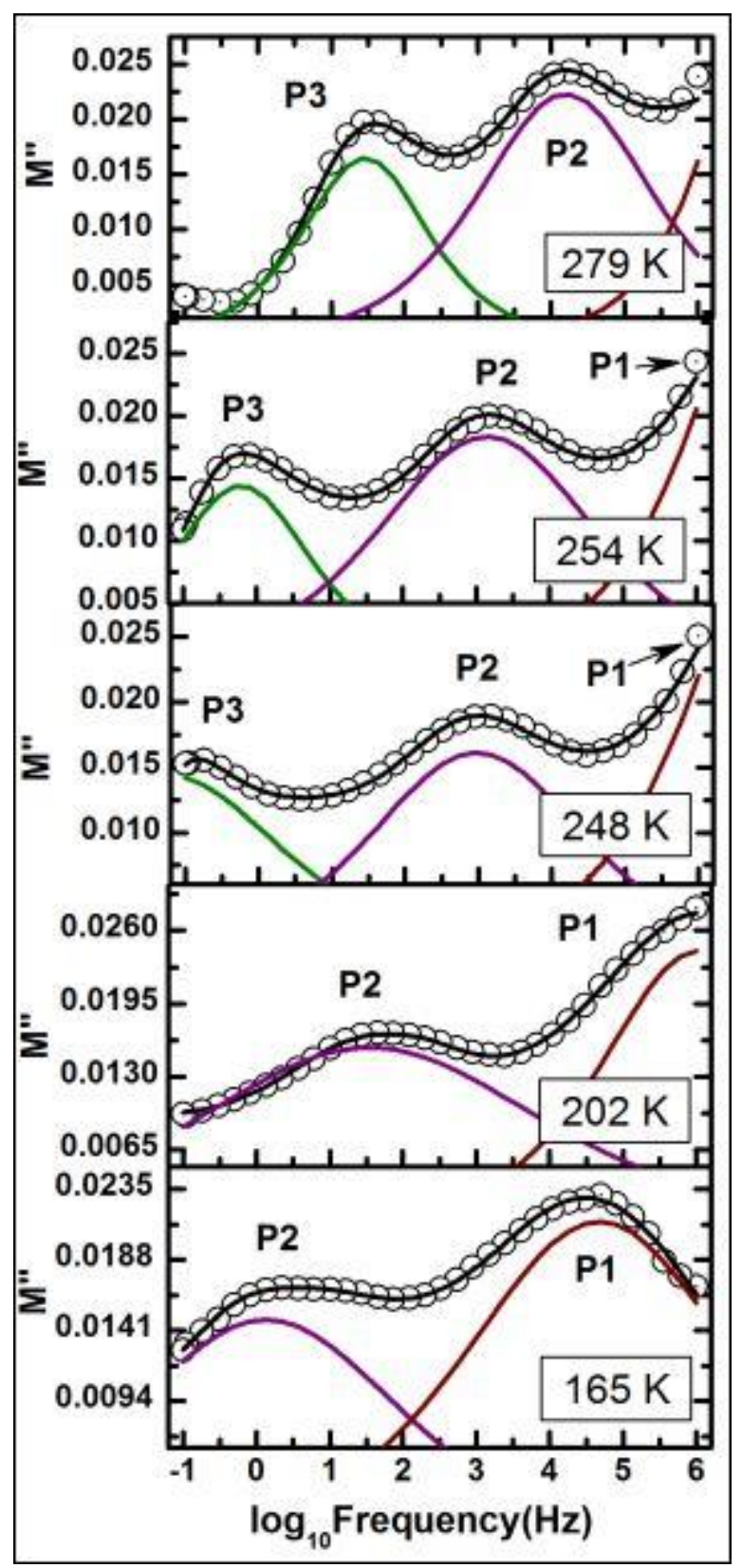

Figure 30 The dielectric modulus vs. frequency functions registered at various temperatures warmed up from the flash-cooled $(155 \mathrm{~K})$ sample, which was obtained from the dehydrated $\mathrm{Ca}_{3} \mathrm{Fe}-\mathrm{LDH}$ allowed to equilibrate under $\mathrm{RH}=11 \%$ at $298 \mathrm{~K}$.

For the sample equilibrated at RH of $11 \%$ (Figure 30 ), then flash-cooled to $155 \mathrm{~K}$ and allowed to warm up gradually, at $165 \mathrm{~K}$, beside the relaxation of physisorbed water (P1), that of the interlayer water (P2) is also seen. Relaxation attributed to structural water is within the frequency window first at $248 \mathrm{~K}$, while the relaxation belonging to P1 is disappearing. The spectrum registered at $278 \mathrm{~K}$ closely resembles that of the equilibrated sample taken at $298 \mathrm{~K}$, i.e., we have returned to the starting point (as it had to happen). 


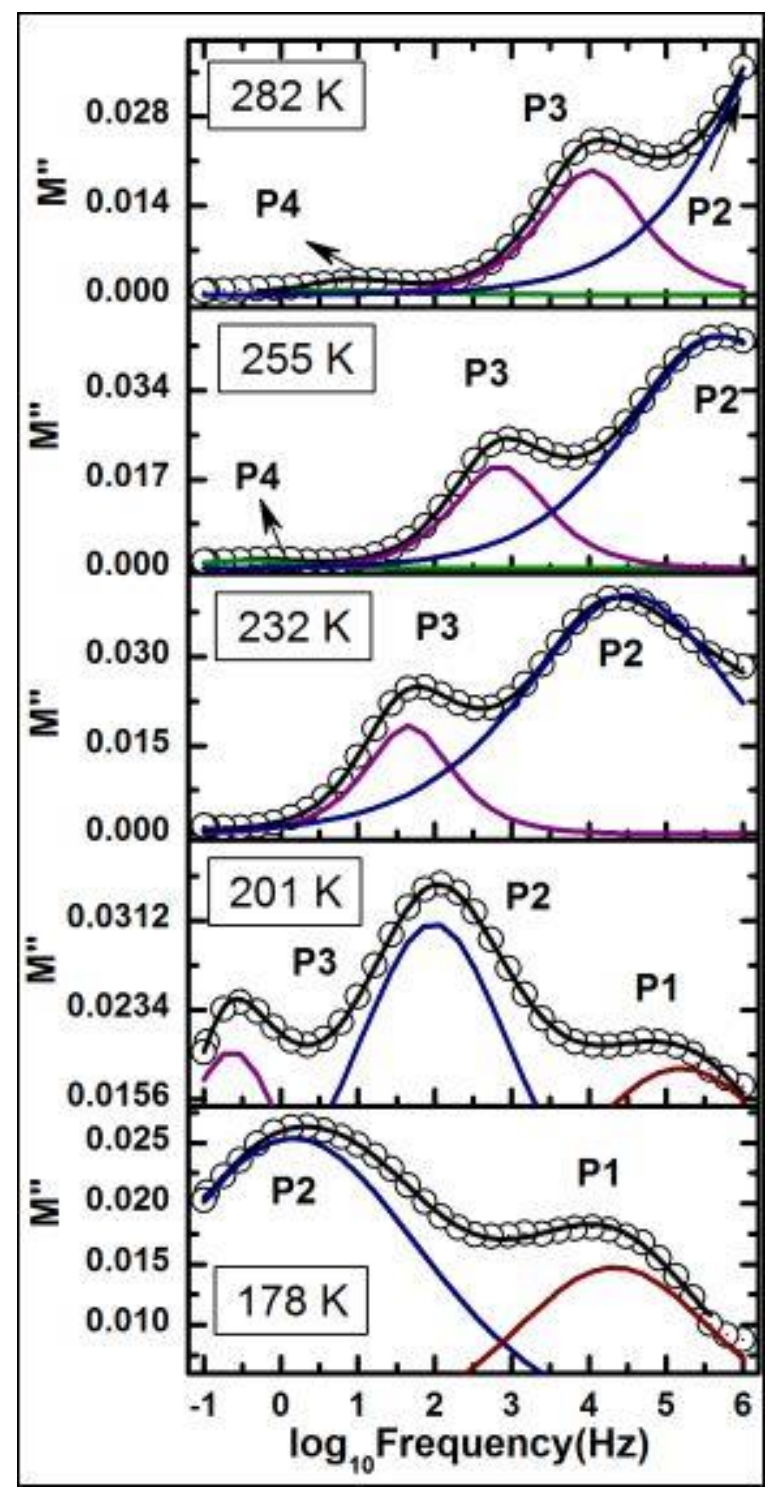

Figure 31 The dielectric modulus vs. frequency functions registered at various temperatures warmed up from the flash-cooled $(155 \mathrm{~K})$ sample, which was obtained from the dehydrated $\mathrm{Ca}_{3} \mathrm{Fe}-\mathrm{LDH}$ allowed to equilibrate under $\mathrm{RH}=43 \%$ at $298 \mathrm{~K}$.

In Figure 31, the imaginary part of the dielectric modulus (M" $(\omega)$ ) vs. frequency functions are displayed for the sample equilibrated at RH of $43 \%$, then flash-cooled to $155 \mathrm{~K}$ and allowed to warm up gradually. At $178 \mathrm{~K}$ beside the relaxation of physisorbed water (P1), that of interlayer water also appears in the frequency window. (Recall that at $155 \mathrm{~K}$ the relaxation of physisorbed water was only seen, and compare to the RH of $11 \%$ sample, where this happened already at $165 \mathrm{~K}$.) At $201 \mathrm{~K}$, the relaxation of structural water comes into range and at $255 \mathrm{~K}$, the MWS polarization (P4) also appears. By this temperature, the relaxation of physisorbed water (P1) gets out of the measurement range completely. Upon reaching $282 \mathrm{~K}$, even the relaxation of interlayer water (P2) has largely disappeared from the frequency window. At room temperature, one only gets a hint that this type of water actually exists. 


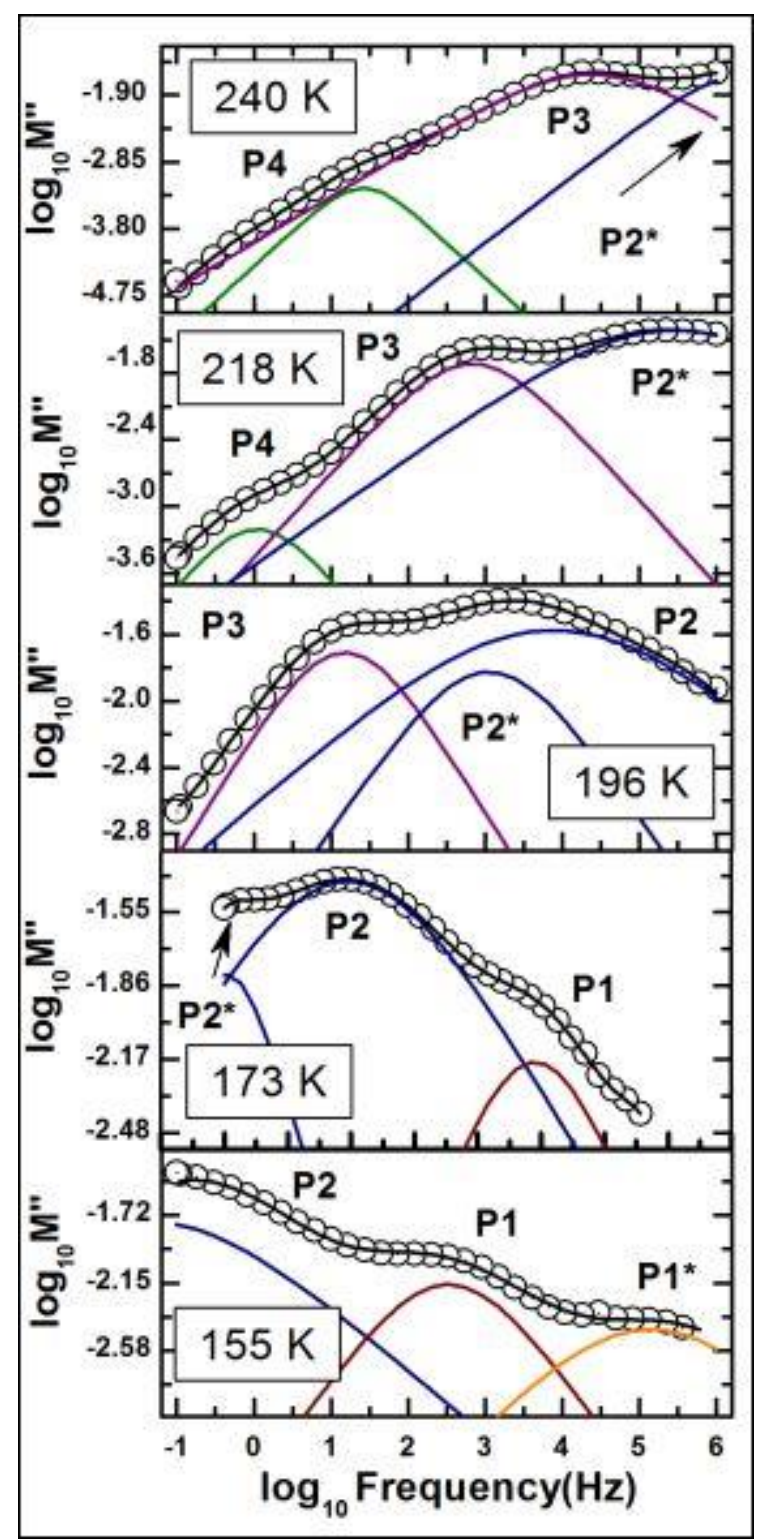

Figure 32 Double logarithmic representation of the imaginary part of the complex electric modulus vs. frequency functions registered at various temperatures warmed up from the flash-cooled $(155 \mathrm{~K})$ sample, which was obtained from the dehydrated CaFe-LDH allowed to equilibrate under $\mathrm{RH}=75 \%$ at $298 \mathrm{~K}$.

For the sample equilibrated at RH of $75 \%$, then flash-cooled to $155 \mathrm{~K}$ and allowed to warm up gradually (Figure 32), multilayers of physisorbed water, and more than one type of interlayer water give 2-2 relaxations at $155 \mathrm{~K}$ and $173 \mathrm{~K}$, respectively. In this sample, there is plenty of water; therefore, it is not surprising that more than one type of water molecules exists in these two positions. Thermal measurements have already indicated this, since the DTG signals assigned to physisorbed as well as to interlayer water molecules were always wide. At this high RH value, these relaxations get out of our measurement range fast with the rise of temperature. By $240 \mathrm{~K}$, only the signal of MWS polarization (P4), the relaxation of structural water (P3) and the slight indication for one type of interlayer water remain 
observable. At room temperature, the spectrum practically does not contain any useful structural information.

From the fitted functions, relaxation times for the various processes could be calculated and their temperature dependence for the samples at different $\mathrm{RH}$ values and processes are shown in Figure 33.

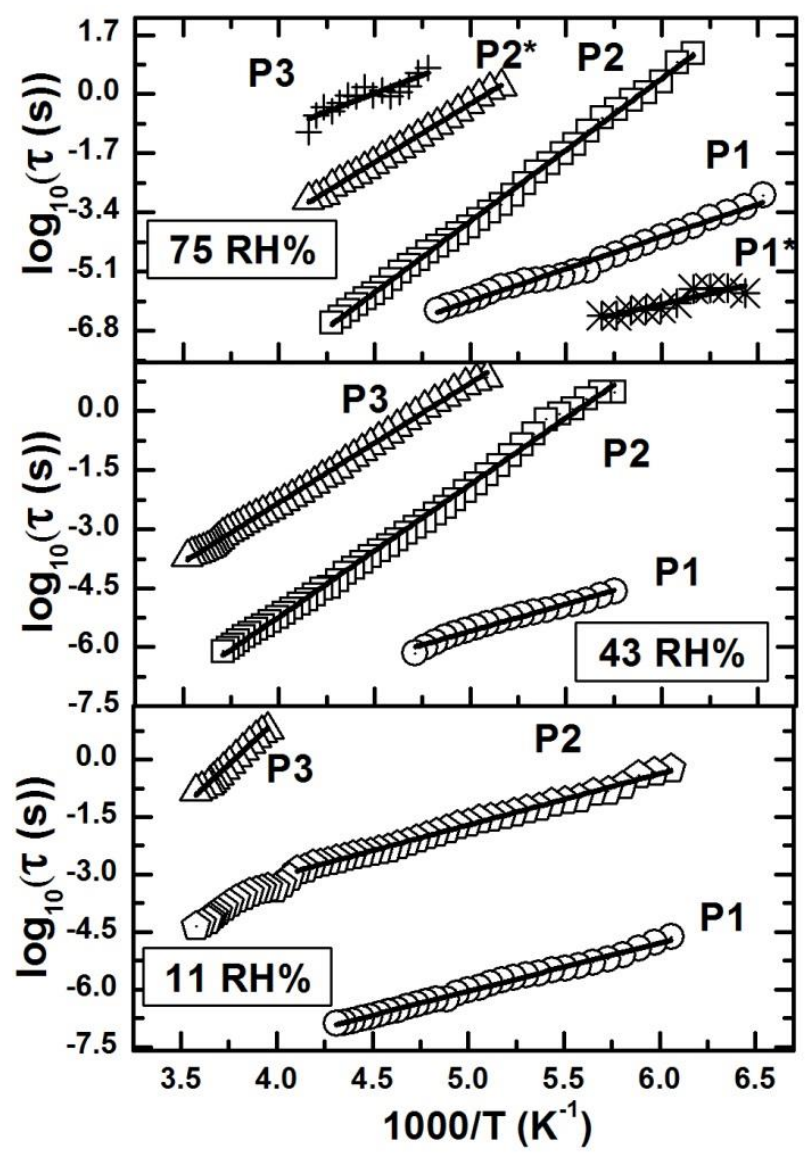

Figure 33 The temperature dependence of relaxation times for the various samples.

All relaxation times follow Arrhenius behaviour in the whole temperature range studied; thus, the activation energies $\left(\mathrm{E}_{\mathrm{a}}\right)$ could be calculated. They are listed in Table 5

Table 5 Activation energies of the various processes for heat-treated $\mathrm{Ca} \mathrm{C}_{3} \mathrm{Fe}-\mathrm{LDH}$ samples equilibrated at various relative humidities $(\mathrm{RH})$, then flash-cooled to $155 \mathrm{~K}$, and allowed to warm up to room temperature.

\begin{tabular}{llllll}
\hline $\mathrm{RH}$ & $\mathrm{P} 1 *(\mathrm{~kJ} / \mathrm{mol})$ & $\mathrm{P} 1(\mathrm{~kJ} / \mathrm{mol})$ & $\mathrm{P} 2(\mathrm{~kJ} / \mathrm{mol})$ & $\mathrm{P} 2 *(\mathrm{~kJ} / \mathrm{mol})$ & $\mathrm{P} 3(\mathrm{~kJ} / \mathrm{mol})$ \\
\hline $11 \%$ & - & 24 & 26 & - & 89 \\
$43 \%$ & - & 26 & 65 & - & 58 \\
$75 \%$ & 23 & 36 & 78 & 64 & 42 \\
\hline
\end{tabular}

The activation energies allow some insight into dynamics of water molecules in the variously hydrated samples during temperature rise. 
In the sample equilibrated at $\mathrm{RH}$ of $11 \%$, physisorbed and interlayer water molecules have about the same mobility and they may change place with each other. However, those water molecules that participated in the partial rehydroxylation of the layers are not mobile any more. The high activation energy indicates that the water molecules at the other two positions do not form an easily accessible reservoir for hydroxylating the layers further.

When the equilibration occurs at RH of $43 \%$ the mobilities of the physisorbed and the interlayer water molecules are not the same, and the rearrangement of water molecules between these two positions are not an easy procedure any more. The activation energies for the interlayer water molecules and for the layer associated water molecules are similar, which may mean that interlayer water molecules may take part in completing the rehydroxylation of the layers and/or the interlayer water molecules and those closely associated with the layers form the same pool.

In the sample equilibrated at $\mathrm{RH}$ of $75 \%$, the easy process is forming multilayers of physisorbed water molecules. Since under these circumstances water molecules are plentiful, various kinds of them are found in the interlayer space closely associated with the hydroxide ions of the layers, and interacting with each other. As the temperature rises, some rearrangement in the interlayer region and the immediate vicinity of the rehydroxylated layers may be expected. But there is no need for the participation of physisorbed water molecules to take part in this procedure.

For the sake of checking whether the stabilising $\mathrm{Ca}(\mathrm{OH})_{2}$ phase altered the relaxation processes related to the various forms of water or not, similar measurements were performed with the phase-pure $\mathrm{Ca}_{2} \mathrm{Fe}-\mathrm{LDH}$ (Figure 34). 


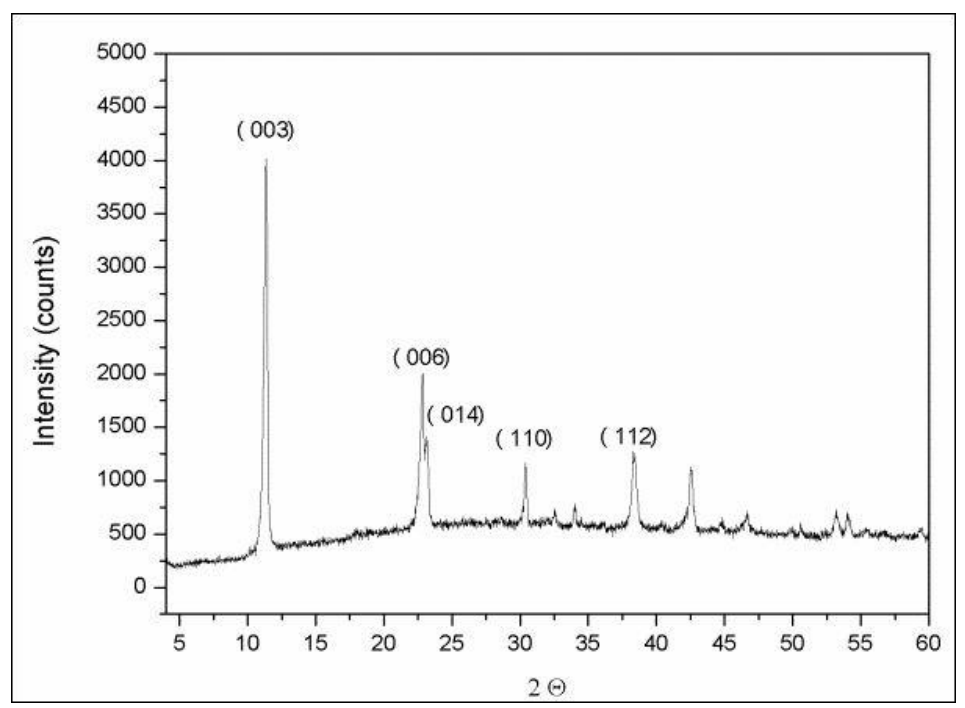

Figure 34 The powder X-ray diffractogram of the $\mathrm{Ca}_{2} \mathrm{Fe}$-LDH sample.

Two samples were dehydrated, and they were partially rehydrated at small (11\%) and medium (43\%) relative humidity values. Figure 35 reveals that the relaxation processes were very similar - only the maxima shifted to higher frequencies - to those of the relevant $\mathrm{Ca}_{3} \mathrm{Fe}-$ LDH samples, i.e., rehydration occurred essentially the same way. The observation that the $\mathrm{Ca}(\mathrm{OH})_{2}$ impurity does not alter the rehydration procedure dramatically, may mean that the $\mathrm{Ca}(\mathrm{OH})_{2}$ is not really a separate entity in the sample, but forms a $\mathrm{Ca}(\mathrm{OH})_{2} / \mathrm{LDH}$ solid protecting interface. This way, it protects the LDH from decomposition on ageing [109].
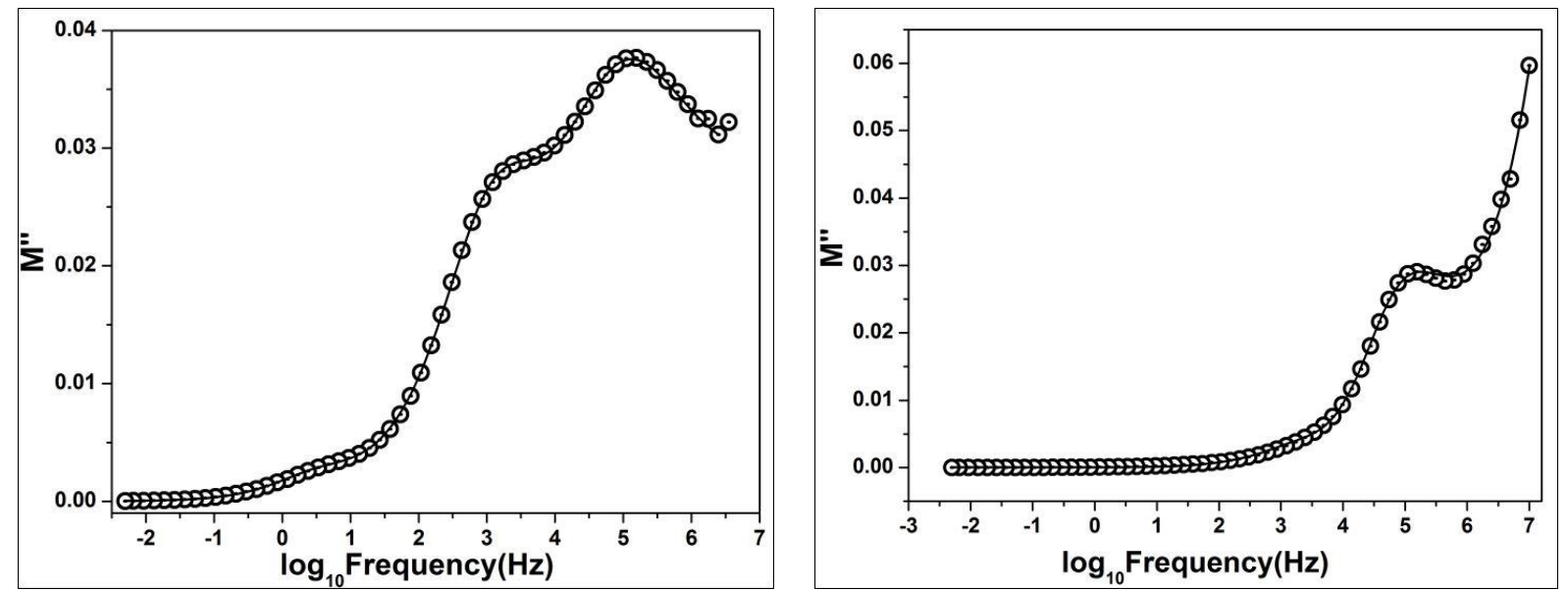

Figure 35 The imaginary part of the electric modulus vs. frequency functions forC $a_{2} \mathrm{Fe}-\mathrm{LDH}$ (phase-pure) samples equilibrated under (a) $11 \%$ and (b) $43 \%$ relative humidity values, fitted with the Cole-Cole function. 


\subsubsection{Rehydration followed by in situ XRD measurements}

The dynamics of that part of rehydration when entering water molecules reconstruct the interlayer space, i.e., when the layers themselves are not dehydrated, was studied by synchrotron-based, in situ X-ray diffractometry. For the necessary mild dehydration, the LDH samples $(\mathrm{CaFe}-\mathrm{LDH}$, and for comparison $\mathrm{MgAl}-\mathrm{LDH}$ prepared in the laboratories of the group) were heated at $200{ }^{\circ} \mathrm{C}$ for 2 hours. At this temperature, the physisorbed and the interlayer water disappeared; however, dehydration of the layers did not occur; thus, the layered structure did not collapse. Approximately $1 \AA$ changes occurred in the basal distances of the LDHs upon rehydration.

To much of our surprise, the mechanism of rehydration for the CaFe-LDH sample distinctly differed from that of the MgAl-LDH one. The change in the basal spacing was a one-step process for CaFe-LDH (Figure 36), while gradual change was observed for the MgAl-LDH (Figure 37), the latter coinciding with the findings of Pérez-Ramirez et al. [129].

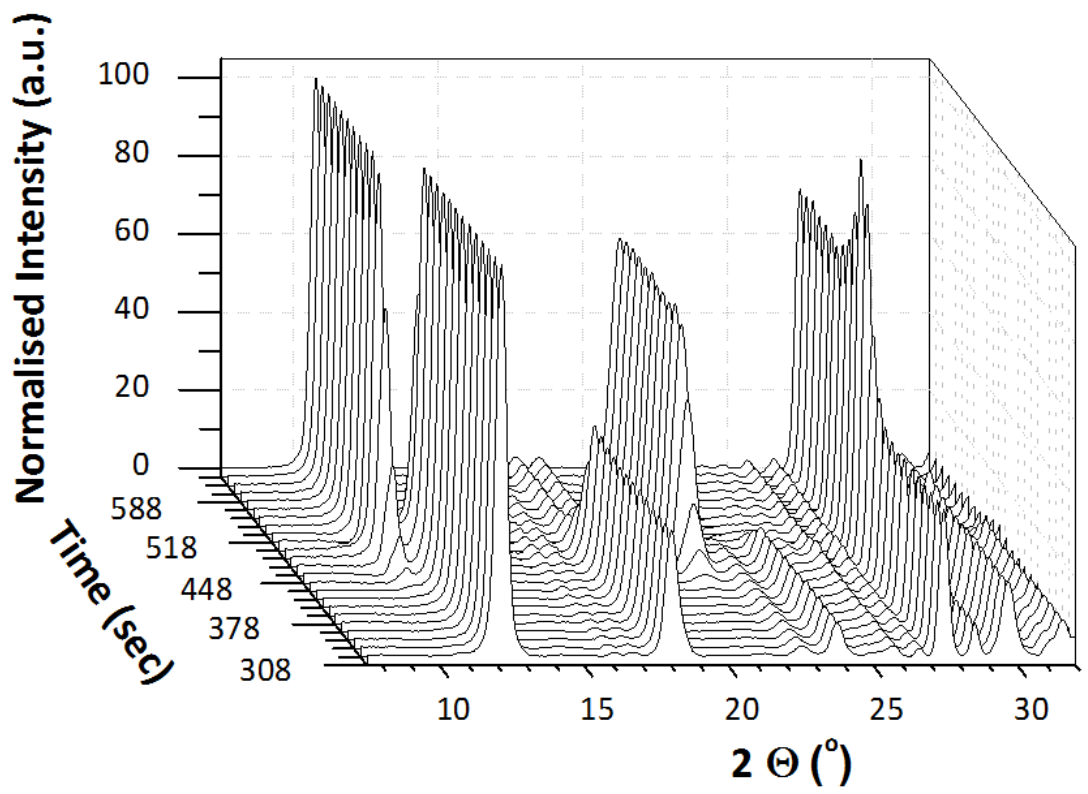

Figure 36 Abrupt change in the basal distance (see, the diffractions at the lowest $2 \Theta$ angles) for $\mathrm{CaFe}-\mathrm{LDH}$, during rehydration in an aqueous ethanol (1:9 volume ratio) flow at $298 \mathrm{~K}$, following a mild dehydration treatment $\left(200^{\circ} \mathrm{C}, 2 \mathrm{~h}\right)$. 


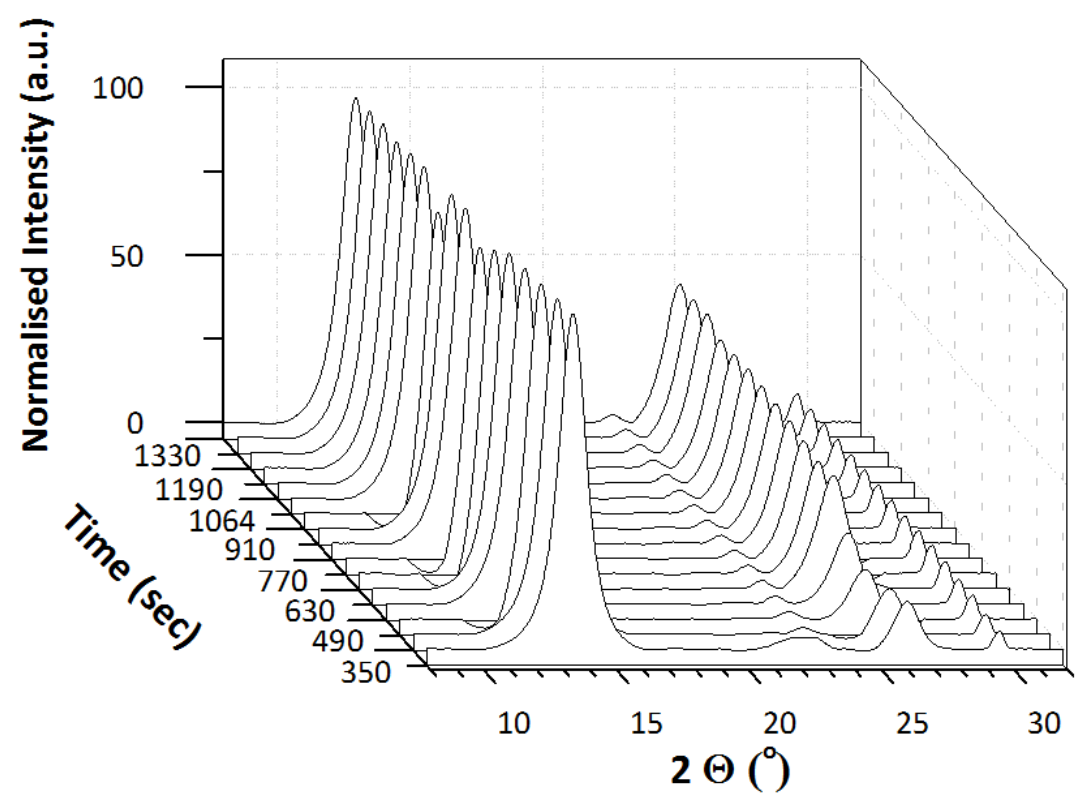

Figure 37 Gradual change in the basal distance (see, the diffractions at around $25^{\circ}$ - they the 006 reflections $-2 \Theta$ angles) for $M g A l-L D H$, during rehydration in an aqueous ethanol (1:9 volume ratio) flow at $298 \mathrm{~K}$, following a mild dehydration treatment $\left(200{ }^{\circ} \mathrm{C}, 2 \mathrm{~h}\right)$.

The reason of the observed phenomena may lie in the different flexibilities of the layers of the two LDH types. The layers of this hydrocalumite-type LDH may be stiffer than those of this hydrotalcite-type LDH. However, broader generalisation, certainly, would need further experiments with other representatives of the types of substructures.

\subsection{Carbon nanotube-layered double hydroxide nanocomposites}

The preparation of multiwalled carbon nanotube (MWCNT)-layered double hydroxide nanocomposites has been attempted by (a) the co-precipitation of the LDH components and the pristine or the surface-treated MWCNT or (b) delaminating the $\mathrm{LDH}$, and applying the layer-by-layer technique. For the MWCNT, two types of surface treatment were used: either the surface was hydroxylated and deprotonated or the nanotube was wrapped in a tenside (dodecylbenzene sulfonate - DBS). The LDH was delaminated by dimethylformamide.

(a) The co-precipitation method is the most often used technique to produce LDHs. The X-ray traces in Figure 38 indicate that CaFe-LDHs were formed, indeed. It is also revealed that MWCNT (pristine or treated) did not enter the interlamellar space, i.e., the $\mathrm{d}(003)$ values only changed insignificantly: in the $0.74-0.77 \mathrm{~nm}$ range). 


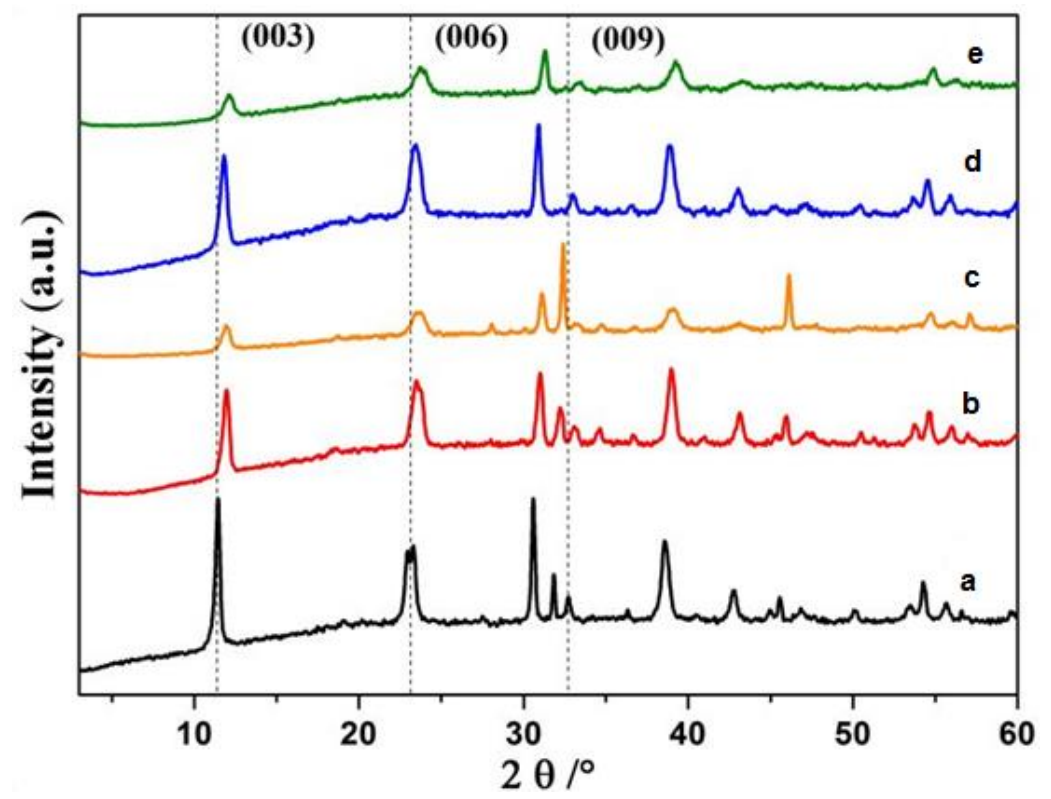

Figure 38 The X-ray diffractograms of $a$ : CaFe-LDH and composites of $b$ : pristine $M W C N T-C a F e-L D H, \quad c:$ oxidatively-treated MWCNT-CaFe-LDH, d: DBS-pristine $M W C N T-C a F e-L D H, e: D B S-$ oxidatively-treated MWCNT-CaFe-LDH.

SEM images show the presence of MWCNT (SEM-EDX elemental maps show the presence of carbon in the samples) in the precipitated solid material, and they are covered, presumably with LDH. These covered nanotubes were only seen when the synthesis mixture contained DBS and pristine MWCNTs (Figure 39) or oxidatively-treated MWCNTs (Figure 40) or DBS and oxidatively-treated MWCNTs (Figure 41).
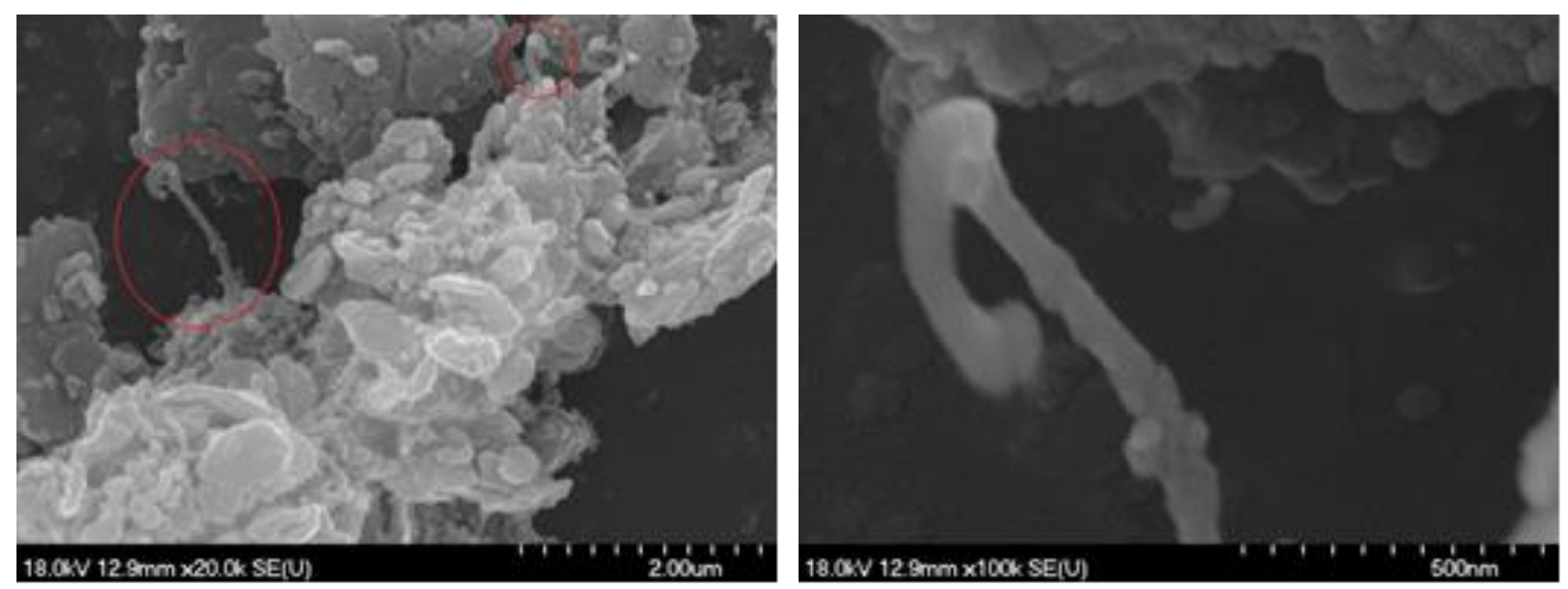

Figure 39 SEM images of the DBS-pristine MWCNT-CaFe-LDH sample (a) magnification: $x 20,000,(b)$ the larger encircled part at x100,000 magnification. 

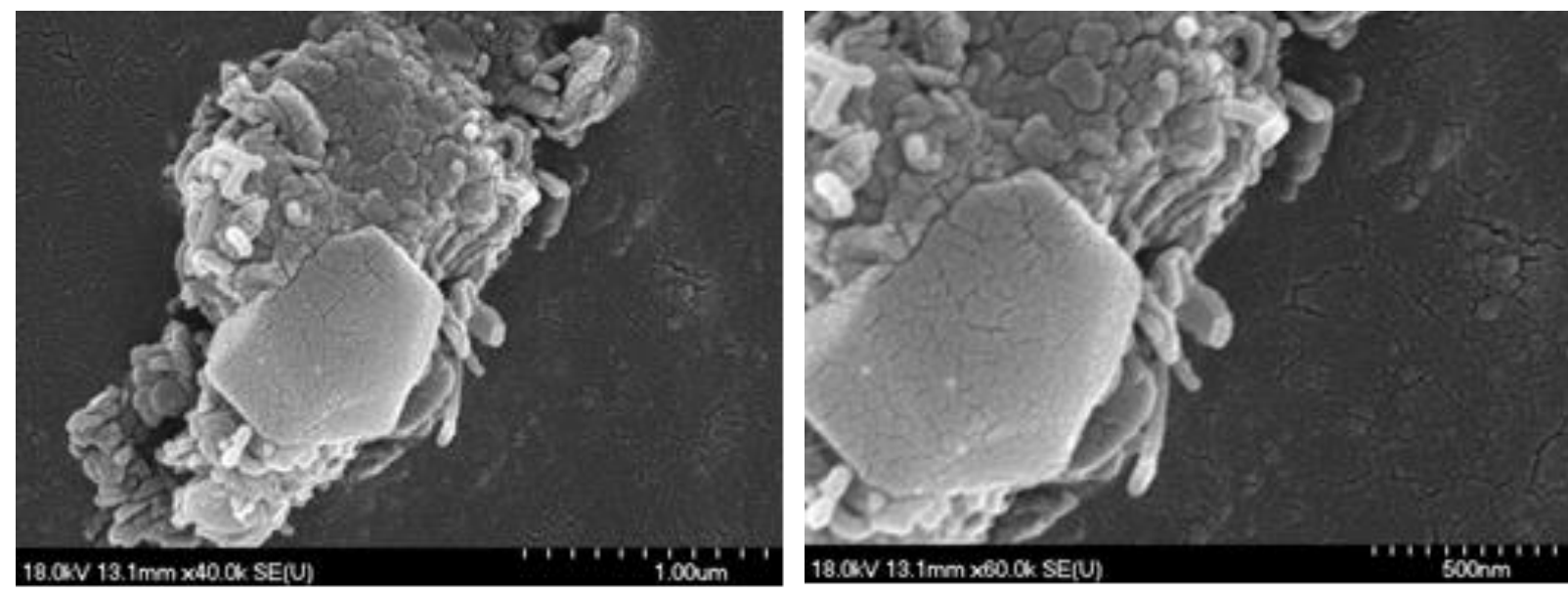

Figure 40 SEM images of the oxidatively-treated MWCNT-CaFe-LDH sample (a) magnification: $440,000,(b)$ magnification: $x 60,000$.
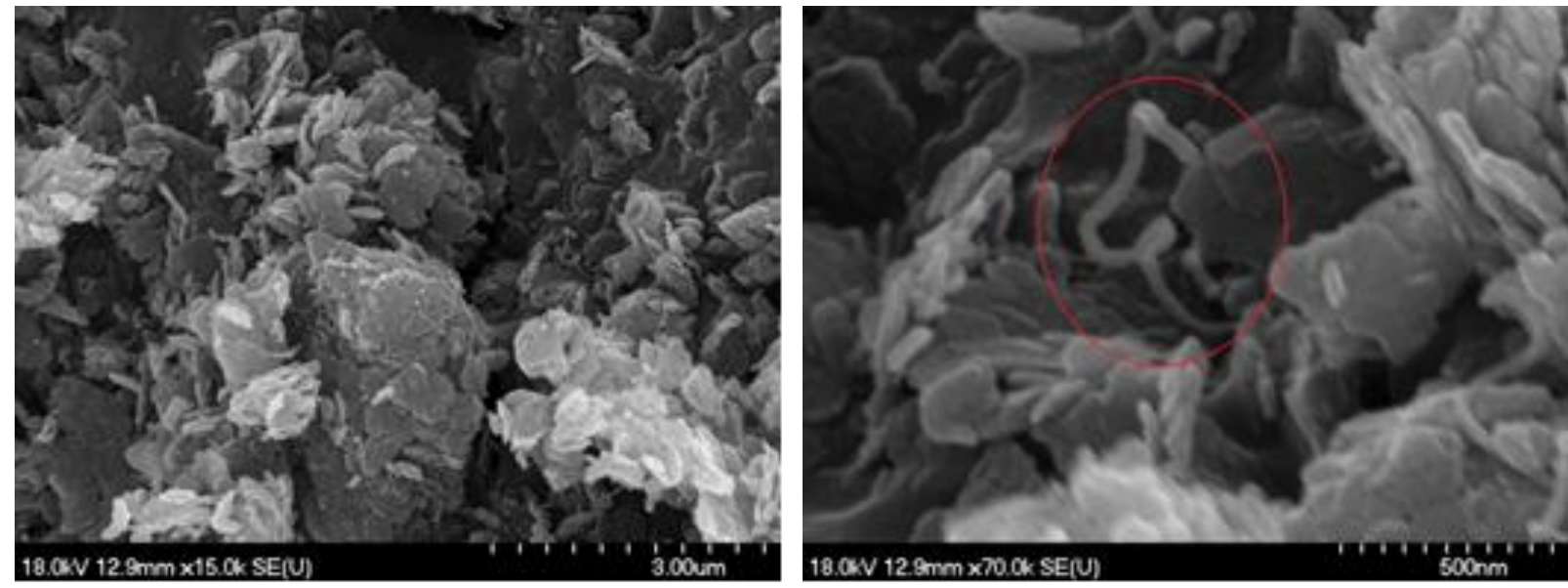

Figure 41 SEM images of the DBS-oxidatively-treated MWCNT-CaFe-LDH sample (a) magnification: x15,000, (b) magnification: x70,000, see, the encircled part.

TEM measurements verify the presence of MWCNT (Figure 42). Even the multiple walls can be observed. Further, the outer surface of the nanotube is not smooth; it is covered with a thin layer of $\mathrm{LDH}$. 


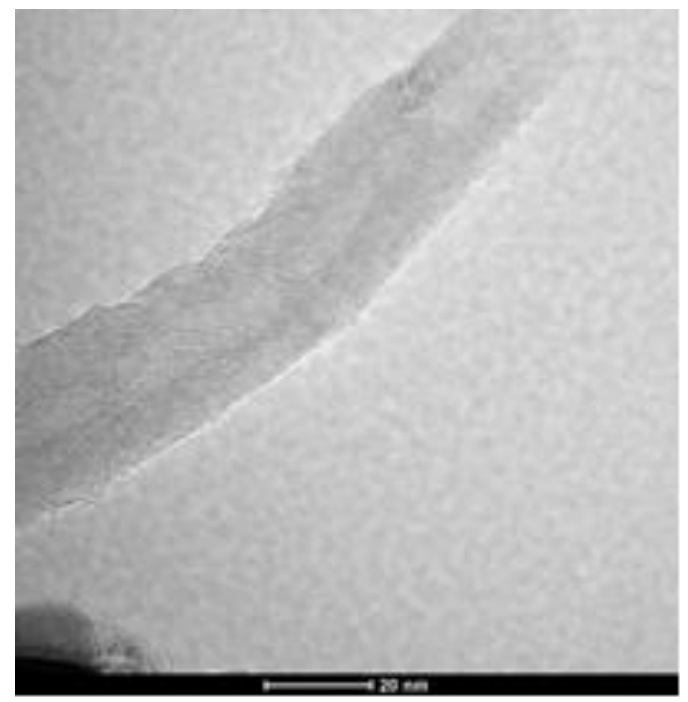

Figure 42 An LDH-covered nanotube from the oxidatively-treated MWCNT-CaFe-LDH composite.

It may be concluded that although interlayer MWCNT-CaFe-LDH could not be prepared, carbon nanotubes provide a good surface for LDH crystallisation only if the MWCNT surface contains enough polar groups or if a surfactant promotes the interaction between the apolar MWCNT and the polar LDH.

(b) The nanocomposite preparation by the layer-by-layer method, to obtain a hierarchically structured nanocomposite consisting of LDH and MWCNT layers, is possible, only if the two materials have compatible polarities. Pristine MWCNTs have quite regular apolar structure; vacancies, dislocations and dangling polar groups are rare, even if the substance was prepared by the CCVD method. Applying a surface-active material like DBS can bridge the polarity gap by adsorption of its apolar part on MWCNT, while its ionic part interacts with the delaminated LDH. Applying the LbL technique, the substances could be layered onto the surface of a thoroughly cleaned quartz slide, as is proven by the SEM image in Figure $43(\boldsymbol{a})$. Scratching the surface of the treated slide revealed that the layers were deposited, indeed (Figure $43(b))$. 


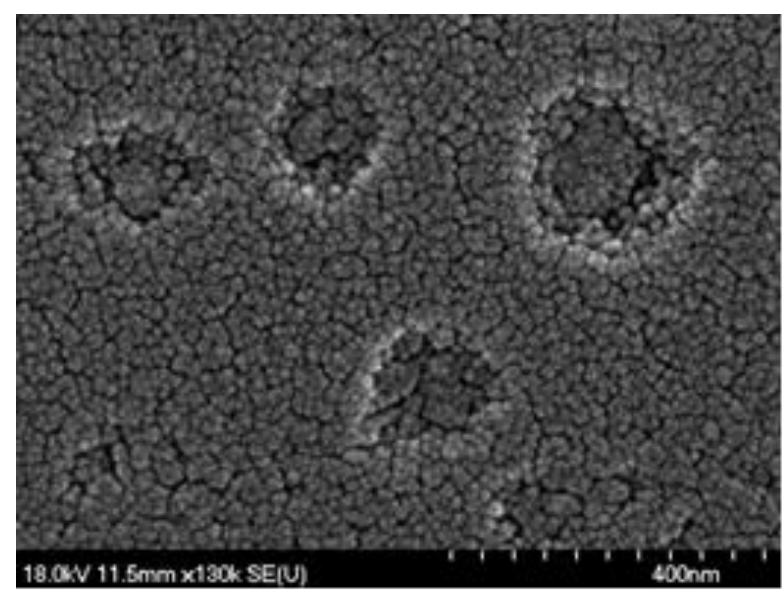

(a)

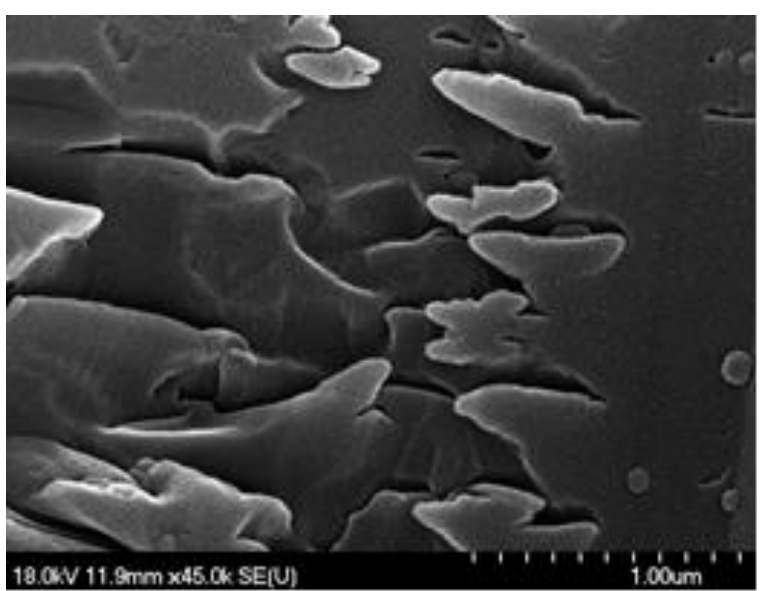

(b)

Figure 43 SEM images of the quartz slide treated by method $(E)$ in order to build MWCNTCaFe-LDH layer-by-layer structure, (a) top view of the deposited material at a magnification of x130,000, and (b) view of the scratched surface of treated slide at a magnification of $x 45,000$.

The X-ray diffractogram in Figure 44 proves that $\mathrm{CaFe}-\mathrm{LDH}$ was delaminated and was deposited on the slide in this form (the $\mathrm{d}(003)$ reflection typical for the stacked structure is missing), and indicates the presence of MWCNTs through the weak, but observable reflection at $26^{\circ} 2 \theta$.

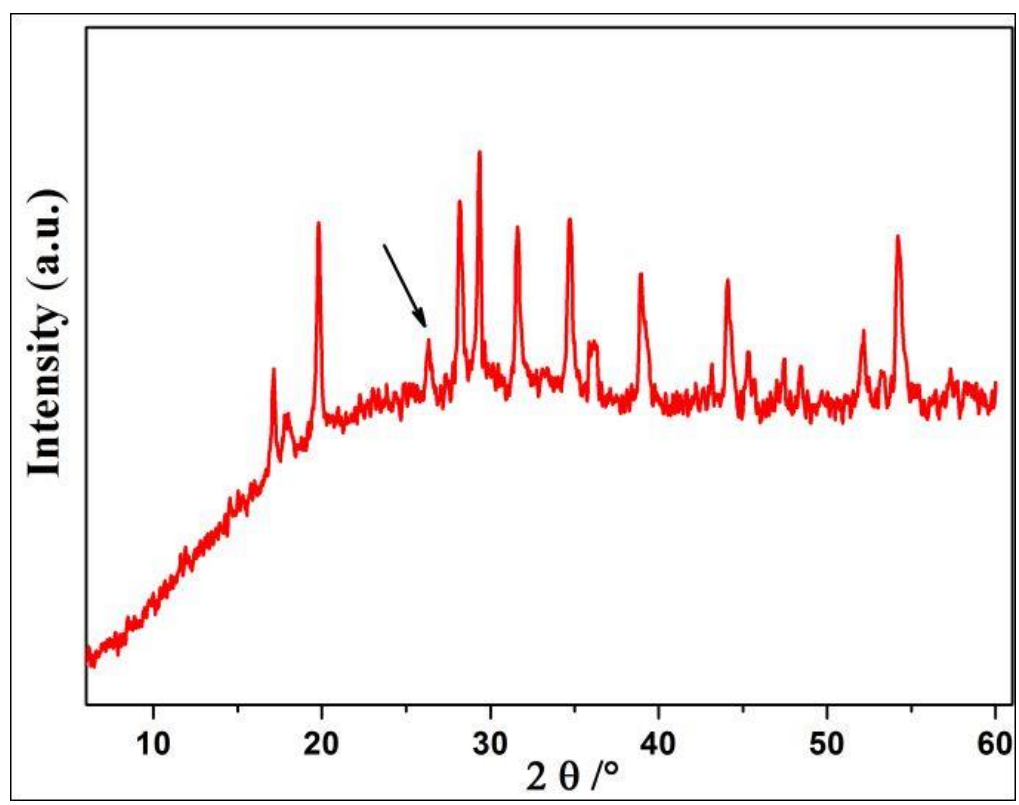

Figure 44 The X-ray diffractogram of LBL-deposited MWCNT-CaFe-LDH nanocomposite; the $L D H$ has been delaminated and the reflection typical for MWCNT is marked by an arrow. 


\subsection{Polyacrylate-CaFe-layered double hydroxide nanocomposites - struct- ural features}

$\mathrm{CaFe}-\mathrm{LDH}$ was prepared by the co-precipitation method, the host materials were calcined at $773 \mathrm{~K}$ for $5 \mathrm{~h}$ in $\mathrm{N}_{2}$ atmosphere before attempting intercalation. The polyacrylate anions were intercalated into $\mathrm{CaFe}-\mathrm{LDH}$ with the dehydration-rehydration technique, utilising the memory effect of the layered double hydroxides. The polyacrylate was suspended in aqueous ethanol, and the aqueous ethanolic suspension of the polyacrylate and the dehydrated LDH was stirred for one week. Upon rehydration, intercalation was expected to occur.

XRD measurements were performed on the pristine $\mathrm{LDH}$, the sodium salt of the polyacrylate as well as the intercalated sample. The diffractograms thus obtained are seen in Figure 45.

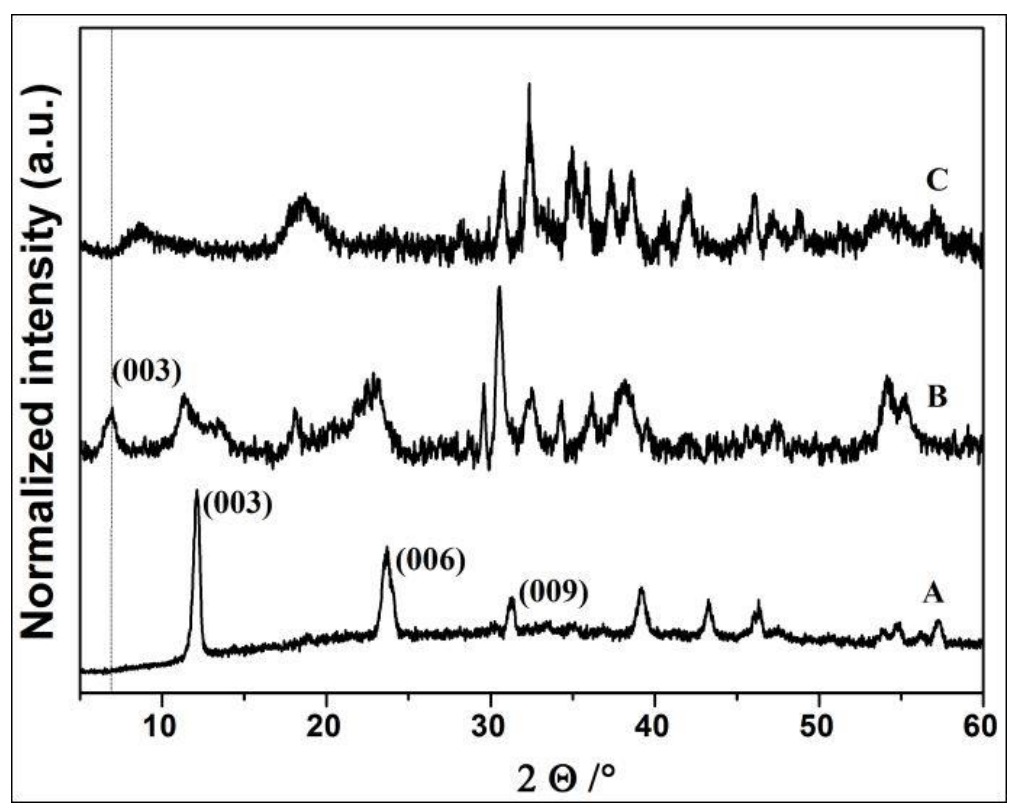

Figure 45 The powder X-ray diffractograms of the host CaFe-LDH (trace A), the polyacrylate-CaFe-LDH (trace B) and the sodium polyacrylate (trace C).

Basal spacing of the polyacrylate-CaFe-LDH was calculated from the (003) reflection, and it was found to be $1.28 \mathrm{~nm}$ (in contrast to $0.77 \mathrm{~nm}$ obtained for the pristine $\mathrm{LDH}$ ). Undoubtedly, the intercalation was successful. The TEM image also verified that the layered structure was retained after the intercalation (Figure 46), in addition, the basal spacing could be estimated to be $1.29 \mathrm{~nm}$ from the image. The agreement with the value calculated from the $\mathrm{XRD}$ pattern, is very reasonable. 


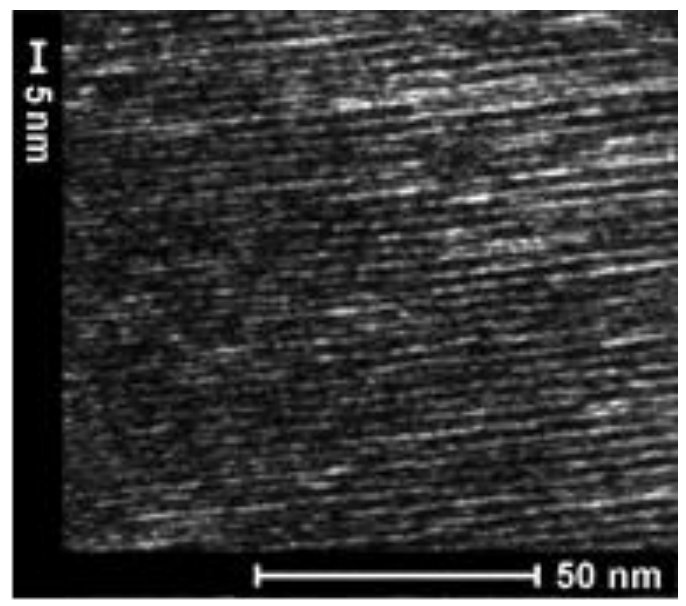

Figure 46 The TEM image of the polyacrylate-CaFe-LDH nanocomposite.

In order to give further proof that the organic material is not simply on the outer surface of the LDH, but it (mainly) resides among the layers, the pristine $\mathrm{LDH}$, the polyacrylate salt as well as the intercalated samples were further studied by scanning electron microscopy (Figure 47).

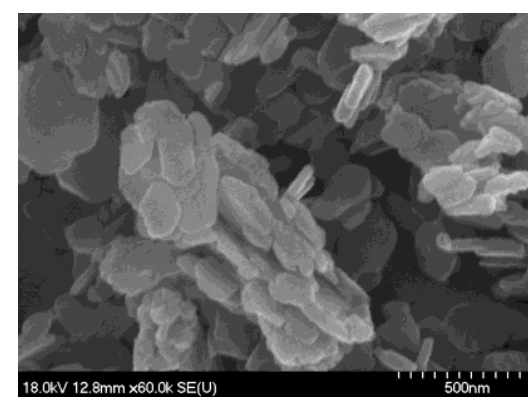

(a)

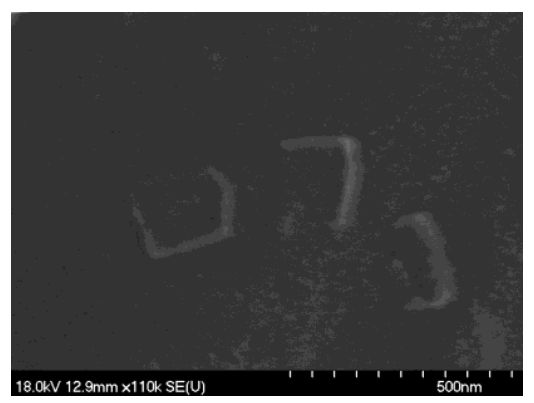

(b)

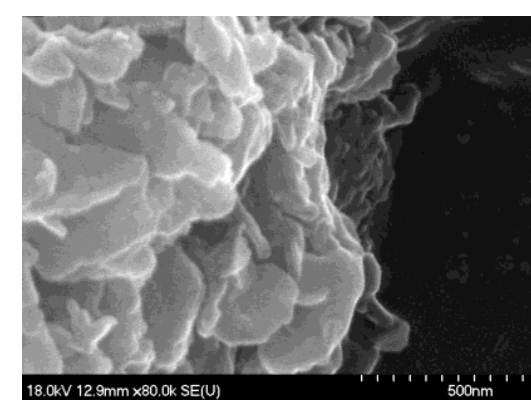

(c)

Figure 47 SEM images of the pristine CaFe LDH (a), the sodium salt of polyacrylate $(b)$ and the polyacrylate-CaFe- $\mathrm{LDH}$.

The lamellar morphologies of the LDHs are reflected in the images both for the pristine LDH (Figure $47(\boldsymbol{a})$ ) and the nanocomposite (Figure $47(\boldsymbol{c}))$. They are very different from that of the salt (Figure $47(\boldsymbol{b})$ ). Elemental maps have also been made (Figure 48) on the basis of SEM-EDX measurements. The close to even distribution of the ions on the $\mathrm{Ca}-\mathrm{Fe}$ elemental map indicated that double hydroxides are formed, indeed (Figure $48(b)$ ). The C elemental map revealed that the organic material was present and again in close to even distribution (Figure $48($ c $)$ ). 


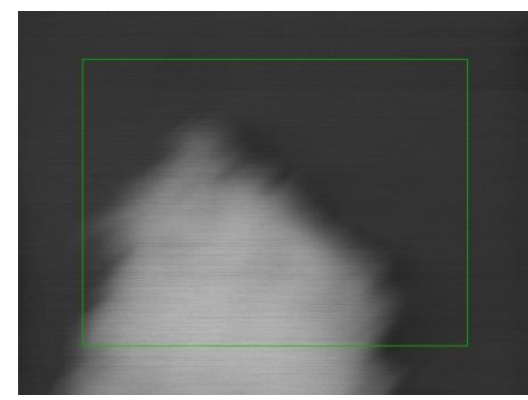

(a)

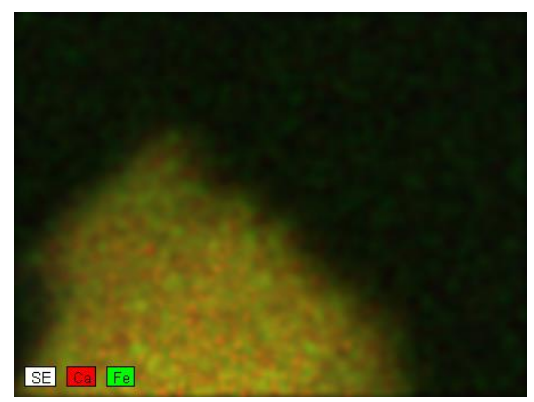

(b)

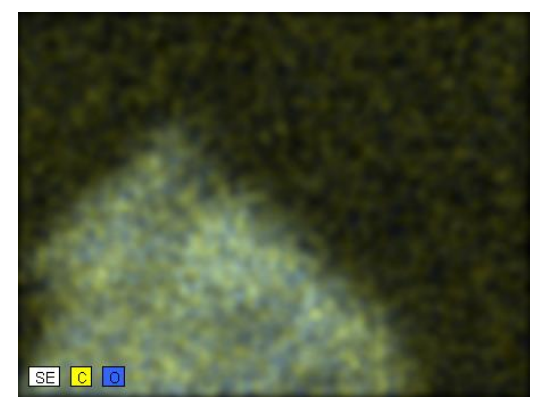

(c)

Figure 48 The SEM-EDX elemental maps of the polyacrylate-CaFe LDH: the sample (a), $\mathrm{Ca}-\mathrm{Fe}$ map (b) and the C-O map (c).

The thermal behaviour of the samples is reflected in Figure 49.

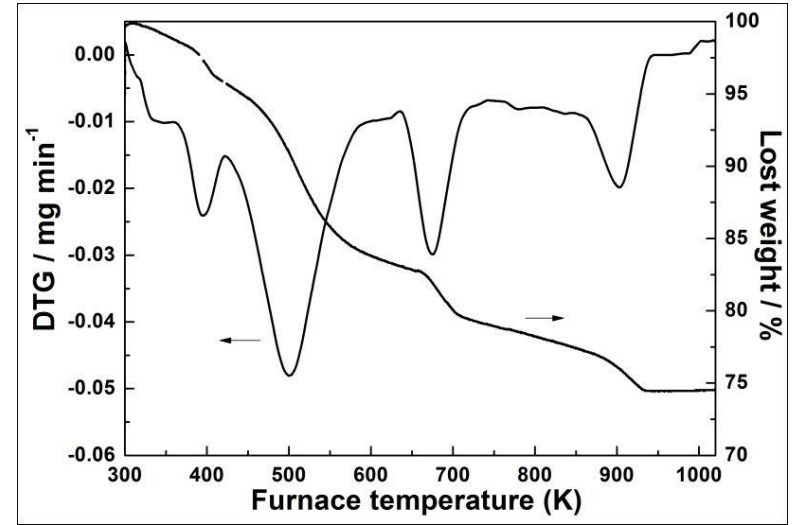

(a)

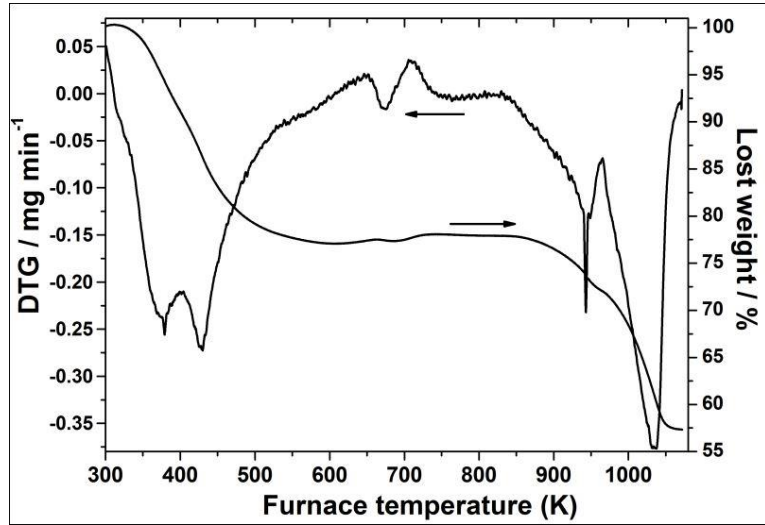

(b)

Figure 49 Thermogravimetric analysis (TG, DTG) of (a) the pristine CaFe-LDH, (b) the polyacrylate-CaFe-LDH.

The pristine CaFe-LDH sample displayed three mass losses attributed to the removal of the physisorbed $(383-423 \mathrm{~K})$, the interlayer $(423-613 \mathrm{~K})$ and the structural $(643-723 \mathrm{~K})$ water. In this last temperature range, the layered structure collapsed gradually. The intercalated structure behaved qualitatively similarly to the pristine one (the second loss slipped towards lower temperatures and thus, the first two DTG bands became less resolved), except that the loss of the organic material is seen in a very narrow temperature range centred at $943 \mathrm{~K}$.

The IR spectra of Na-polyacrylate, the pristine $\mathrm{CaFe}-\mathrm{LDH}$ and the polyacrylate- $\mathrm{CaFe}$ LDH are seen in Figure 50. That of the CaFe-LDH sample displays a peak (trace coloured blue) at $3643 \mathrm{~cm}^{-1}$, which can be assigned to isolated $\mathrm{OH}$ groups. This is structural $\mathrm{OH}$, and it is seen on the polyacrylate- $\mathrm{CaFe}-\mathrm{LDH}$ sample too. The broad bands above $3000 \mathrm{~cm}^{-1}$ on each spectrum indicate hydrogen-bonded $\mathrm{OH}$ networks. They may also belong to associated structural $\mathrm{OH}$ groups; however, physisorbed water may also contribute. Physisorbed water is not only present on the LDH samples, but in/on the polyacryalate as well, since it is known 
that polyacrylate retards a large amount water (which is the reason why polyacrylate is used in, e.g., disposable nappies). A band around $1620 \mathrm{~cm}^{-1}$ is seen in the spectra of the LDH samples. It is assigned to the deformation vibration of the interlayer water molecules. Bands around $1000 \mathrm{~cm}^{-1}$ may be assigned to the $\mathrm{O}^{-}$-metal ion-O units of the LDH layers [119]. The band at $1638 \mathrm{~cm}^{-1}$ in the spectrum of the polyacrylate salt is assigned to the $\mathrm{C}=\mathrm{C}$ double bond [95]. Obviously, the comparison of the spectra verify the presence of polyacrylate units with the $\mathrm{CaFe}-\mathrm{LDH}$, and together with the previously discussed result provided by the various methods, we know that the polyacrylate ions are among the layers of the $\mathrm{LDH}$.

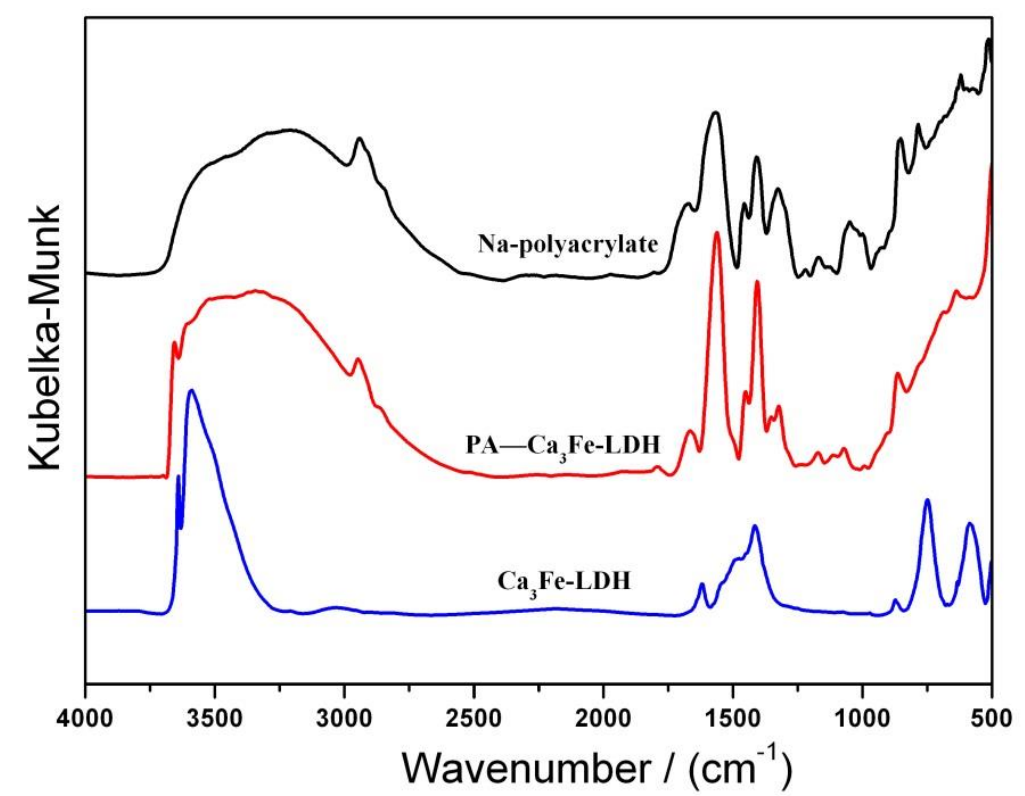

Figure 50 FT-IR spectra of the CaFe-LDH (blue), the polyacrylate(PA)-CaFe-LDH (red), and the Na-polyacrylate (black) samples.

\subsubsection{Dielectric features of the polyacrylate-CaFe-layered double hydroxide nanocomposites}

In order to display changes in the dielectric relaxation spectrum of polymer due to confinement, the spectra of the sodium polyacrylate, the polyacrylate-CaFe- $\mathrm{LDH}$, and the pristine $\mathrm{CaFe}-\mathrm{LDH}$ were registered at $298 \mathrm{~K}$. For evaluation, the Havriliak-Negami parameterised [120] Debye equation, including the conductivity and the electrode polarisation terms was fitted to the observed DRS data points. In Figure 51 the imaginary part of permittivity $v$. frequency spectra are depicted. 


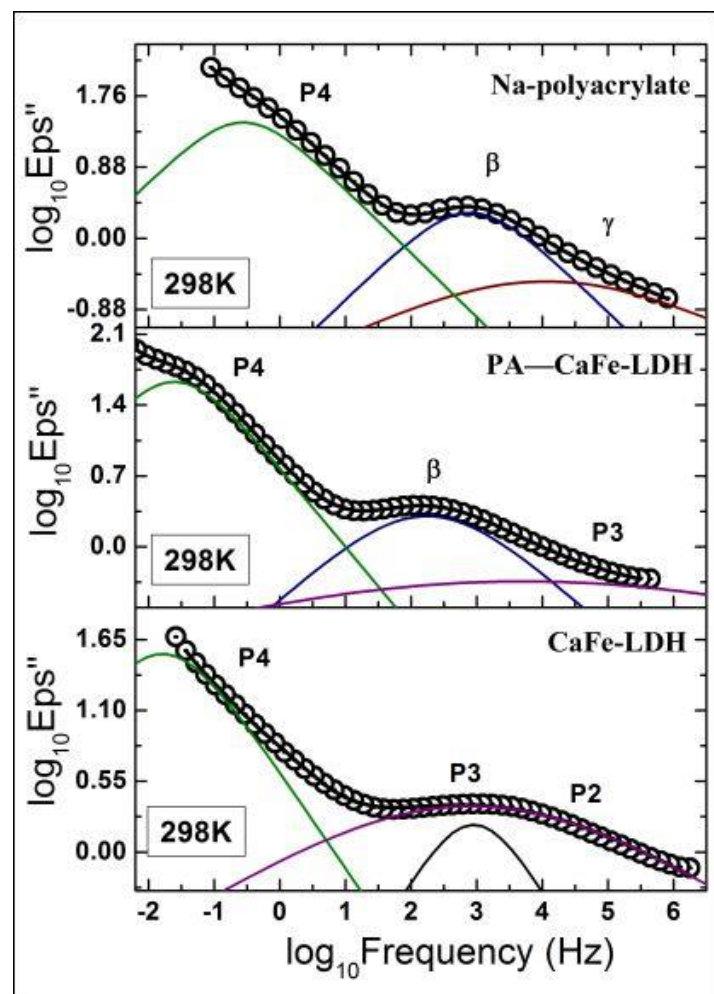

Figure 51 The double logarithmic representation of the permittivity vs. frequency data measured at $298 \mathrm{~K}$ for the pristine CaFe-LDH (bottom), the polyacrylate(PA)-CaFe-LDH nanocomposites (middle) and the sodium polyacrylate (top).

The dielectric spectrum of the pristine $\mathrm{CaFe}-\mathrm{LDH}$ is similar in appearance to other watercontaining materials, such as zeolites [130], clay minerals [131], etc. At this temperature, three relaxations can be identified. They reflect two major and one minor relaxation processes. At the lowest frequency, the hardly visible minor one is assigned to interfacial polarisation process ( $\mathrm{P} 4$ - MWS process) resulted from the accumulation of charges at the interfaces [124]. The second relaxation (P3) is attributed to the hydroxylic groups of the layers, i.e., to structural $\mathrm{OH}$ groups, and water molecules attached to them via strong hydrogen bonds [125]. The relaxation, due to interlayer water molecules (P2), is also seen at higher frequencies [125].

Beside the MWS peak in the dielectric spectrum of Na-polyacrylate, two relaxations are also observed. The more intense is called $\beta$-relaxation and it corresponds to the dynamic glass transition related to segmental fluctuations. The third one is the $\gamma$-relaxation, corresponding to localised fluctuations within the amorphous regions [132-134].

These relaxations - except $\gamma-$ are also present in the polyacrylate-CaFe-LDH nanocomposite; however, they are shifted towards higher frequencies with about an order of magnitude, respectively. The intensity of the relaxation at the lowest frequency, which is 
attributed to interfacial polarisation, increased due to the increased inhomogeneity of the system.

In order to display changes in the DRS spectrum of the polymer due to confinement, a similar experimental protocol was applied as described in subchapter 5.2: sodium polyacrylate, the pristine $\mathrm{CaFe}-\mathrm{LDH}$ and the polyacrylate-CaFe-LDH were flash-cooled to $155 \mathrm{~K}$; then, they were allowed to warm-up gradually. The DRS spectra were registered at $155 \mathrm{~K}$ and, along with the warm-up process, by $2.5 \mathrm{~K}$ temperature intervals.

The dielectric relaxation spectrum of the pristine $\mathrm{LDH}$ at $298 \mathrm{~K}$ has already been discussed above. At lower temperatures, the four relaxations appear at lower frequencies - the phenomenon has also been explained previously.

The dielectric behaviour of polymers with a high degree of crystallinity like sodium polyacrylate, in general, follows a sequence of relaxation processes different from that of the amorphous ones [102, 133]. Figure 52 displays the dielectric behaviour of sodium polyacrylate $v s$. frequency and temperature in a $3 \mathrm{D}$ representation. As it has been described for the spectrum taken at $298 \mathrm{~K}$, the dielectric spectra of sodium polyacrylate show one main relaxation process ( $\beta$ relaxation), and a minor one ( $\gamma$ relaxation). With increasing temperature (the 218-282 K temperature range is depicted), they shift to higher frequencies as expected. Conduction effects are also seen in the sample, since the presence of internal crystal boundaries results in local charge blocking and an additional contribution to the overall polarisation.

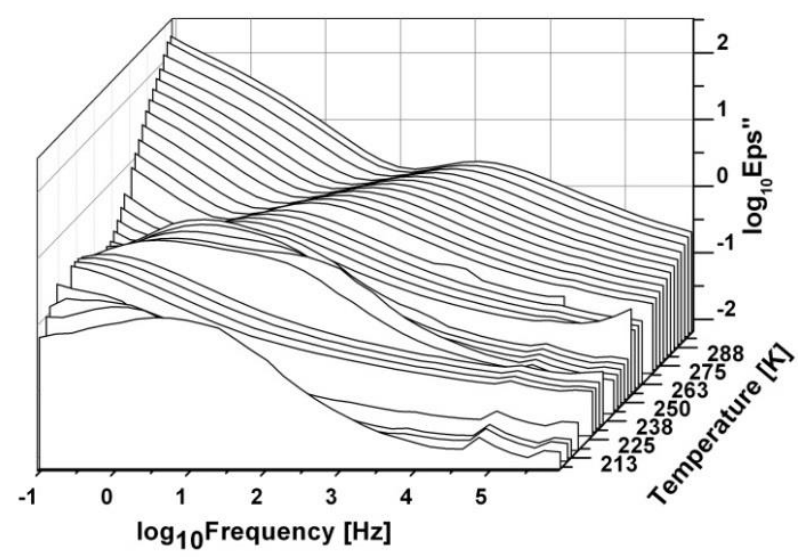

(a)

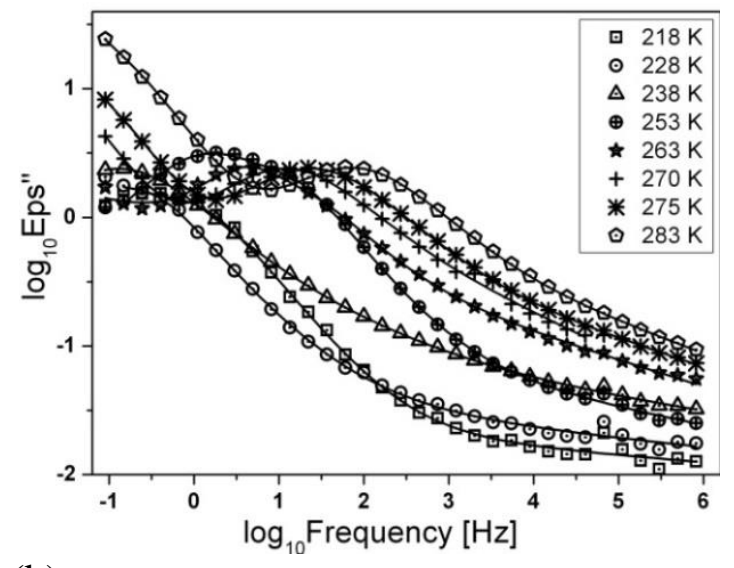

(b)

Figure $523 D$ relaxation contour map for Na-polyacrylate (a), and the imaginary part of the complex dielectric function obtained by isothermal frequency scans $(b)$.

Figure 53 shows the dielectric spectra for the polyacrylate-CaFe-LDH nanocomposite, also in a $3 \mathrm{D}$ representation, in the same temperature range $(218-282 \mathrm{~K})$. 
At lower temperature and higher frequency, the interlayer water (P2) relaxation is seen, like for the pristine $\mathrm{CaFe}-\mathrm{LDH}$. At higher temperatures the $\beta$ relaxation belonging to sodium polyacrylate is observed. At $208 \mathrm{~K}$, the relaxation of structural water comes into range and at $239 \mathrm{~K}$, the MWS polarization (P4) also appears.
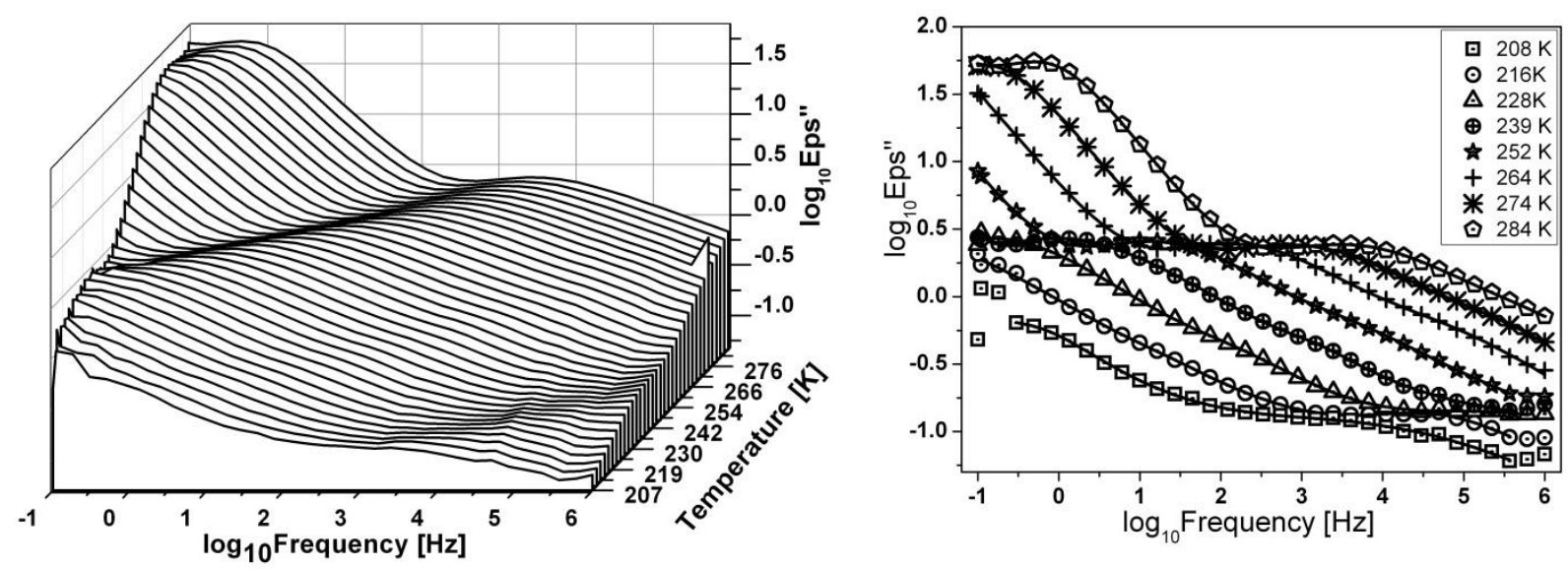

Figure $533 D$ relaxation contour map for polyacrylate-CaFe- $L D H$ nanocomposite (a), and the imaginary part of the complex dielectric function obtained by isothermal frequency scans (b).

The relaxation times vs. temperature characteristics for the relaxations are presented in the form of Arrhenius plots $\left(\log _{10} \tau\right.$ vs. 1000/T) for the three sample types (pristine CaFeLDH, polyacrylate-CaFe-LDH nanocomposite, sodium polyacrylate).

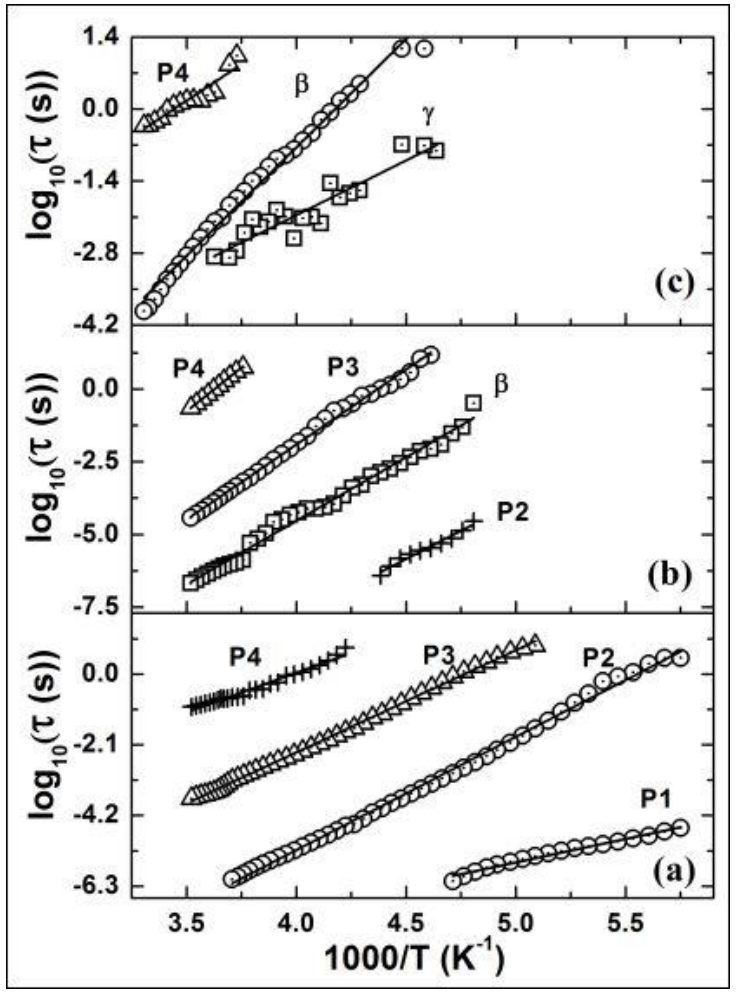

Figure 54 Arrhenius plots of relaxation times $\log _{10 \tau}$ vs. 1000/T for the pristine CaFe-LDH $($ a), the polyacrylate-CaFe-LDH nanocomposite $(b)$ and the sodium polyacrylate (c). 
The obtained activation energies are reported in Table 6 .

Table 6 Activation energies of the various processes for the pristine CaFe-LDH (LDH), the sodium polyacrylate (PA) and the polyacrylate-CaFe-LDH nanocomposite (PA-LDH).

$\begin{array}{llllll}\mathrm{P} 1(\mathrm{~kJ} / \mathrm{mol}) & \mathrm{P} 2(\mathrm{~kJ} / \mathrm{mol}) & \beta(\mathrm{kJ} / \mathrm{mol}) & \gamma(\mathrm{kJ} / \mathrm{mol}) & \mathrm{P} 3(\mathrm{~kJ} / \mathrm{mol}) & \mathrm{P} 4(\mathrm{~kJ} / \mathrm{mol})\end{array}$

\begin{tabular}{lcccccc}
\hline PA-LDH & - & 74.1 & 84 & - & 99 & 115 \\
PA & - & - & 81 & 41 & - & 40 \\
LDH & 26 & 65 & - & - & 58 & 45 \\
\hline
\end{tabular}

The activation energies of the relaxations, obtained from the slopes of Arrhenius plots corresponding to Na-polyacrylate, are $81 \mathrm{~kJ} / \mathrm{mol}$ and $41 \mathrm{~kJ} / \mathrm{mol}$ for the $\beta$ and $\gamma$ relaxations, respectively, which show good agreement with data published in the literature [132, 134, 135]. In the nanocomposite, the only observed $\beta$-relaxation has activation energy of 84 $\mathrm{kJ} / \mathrm{mol}$. The others are the well-known relaxations of the CaFe-LDH host.

On the basis of the data discussed above, a structural model may be proposed. For the polymer-LDH composite three relaxation processes could be identified. Two of them belong to the host, and one to the polymer guest, meaning that even in the intercalated state it retained some mobility. Since it is known that the polymer binds water very strongly, it is highly improbable that the retained mobility belongs to the intercalated polyacrylate. Rather, one can envisage a structural model in which part of the polymer chains are intercalated, while the remaining parts wrap around the LDH. The intercalated part lost, but the adsorbed part largely kept mobility. 


\section{SUMMARY}

The focus of the experimental work leading to this dissertation is the description of the structural properties of $\mathrm{CaFe}-\mathrm{LDH}$, a layered double hydroxide of the hydrocalumite type. Its dehydration-rehydration (with emphasis on the latter) was of our main interest. It was not only intriguing for its own sake, but it is a major technique in the synthesis of host-guest composites, in which anions of various complexities are intercalated among the layers of the CaFe-LDH host.

Comprehensive information was obtained with a large variety of experimental methods like microscopic techniques (TEM, SEM, SEM-EDX), thermal methods, FT-IR, ${ }^{57} \mathrm{Fe}$ Mössbauer and dielectric relaxation spectroscopies, and as the major method, X-ray diffractometry (both static and the time-dependent versions). Very often, the results obtained with the different methods were of complementary nature, and had to be used in sophisticated ways.

In the first part of the dissertation, the experimental work concerning the rehydration of the dehydrated CaFe-LDH is described, and the results obtained are discussed.

Upon heat treatment at $773 \mathrm{~K}$, the layered structure of the pristine CaFe-LDH collapsed. The structural decomposition was followed by thermal methods, and the temperature ranges for the weight losses could be separated. They could be assigned to the different positions of the water molecules and to structural $\mathrm{OH}$ groups. Keeping in mind these temperature ranges, the dehydrated sample was separated to a number of portions, and they were partially, and at higher relative humidities, fully rehydrated. The steps of the rehydration procedure were identified, and followed by static and time-dependent X-ray diffractometry, thermogravimetry, dieletric relaxation, FT-IR and ${ }^{57} \mathrm{Fe}$ Mössbauer spectroscopies.

Three rehydration steps were identified - they were called processes in the dissertation. These steps were found to be sequential, although overlaps could be observed. First, the dehydroxylated layers started to rehydroxylate; however, in an overlapping process, the reappearance of interlayer water also began. Physisorbed water molecules could also be identified before the full reconstruction of the interlamellar space finished.

Beside the frequently used X-ray diffractometry, thermogravimetry and FT-IR spectroscopy, dielectric relaxation spectroscopy was of great help in identifying these processes (and the MWS polarisation too, which may be considered to be an annoying effect in respect of the structural reconstruction). Its full potential could only be used by applying a useful trick. This was the flash-cooling of the partially rehydrated sample, and while 
registering the spectra, allowing its warm-up to ambient temperature. This way, those types of water molecules which slipped out of our measurement window at room temperature could be observed as well, i.e., samples were measurable after rehydration in a broader relative humidity range. The ability of measuring temperature dependence allowed us to determine the activation energies of these processes.

Measurements by synchrotron-based, time-dependent X-ray diffractometry enabled us to observe that a CaFe-LDH sample mildly dehydrated (physisorbed and interlayer water molecules were only removed, the layers remained largely intact) abruptly rehydrated in a flow-through aqueous stream. However, rehydration was gradual for a hydrotalcite-like sample (MgAl-LDH) dehydrated in the same way.

${ }^{57} \mathrm{Fe}$ Mössbauer spectroscopy is able to give structural information about the immediate environment of the $\mathrm{Fe}(\mathrm{III})$ ion in the $\mathrm{CaFe}-\mathrm{LDH}$ and also on its heat-treated derivatives. This ability was used in studying the structure of the transformed phase left behind after heat treatments at various temperatures. This type of spectroscopy, together with $\mathrm{X}$-ray diffractometry on these residues, complemented with literature information, allowed us to deduce novel structural information on these phases.

Since the charge-compensating anions among the layers can be altered with relative ease, one has a handy way of obtaining LDH-based nanocomposites. During our experimental work, we have attempted the synthesis of (multiwalled) carbon nanotube-CaFe-LDH nanocomposite, since it seemed to be a functional material with many potential applications. Furthermore, it was a real challenge, since the carbon nanotube is an uncharged apolar substance (even if the method of synthesis, the CCVD method that is, leaves substantial amount of defects on its surface), and the LDH is polar with positively charged layers; therefore, several modifications had to be made. Fitting in the line of our dehydrationrehydration investigations, the dehydration-rehydration method of intercalation was tried first. It did not work, even when, e.g., the surface of the carbon nanotube was treated with oxidising acids to obtain surface $\mathrm{OH}$ and/or carboxylic groups in sizeable amounts. Wrapping the pristine or surface-oxidised carbon nanotube in a tenside to bridge polarity differences; however, a composite was obtained, where the carbon nanotube was covered by a thin layer of LDH. Finally, the layer-by-layer method worked. Delaminated LDH and carbon nanotube suspensions were prepared. Successive dipping a quartz slide in these suspensions following an elaborate dipping/washing protocol provided with a hierarchical nanotube-LDH composite.

The dehydration-rehydration intercalation method did work with the polyacrylate ion. A nanocomposite with the polyacrylate ions among the layers of $\mathrm{CaFe}-\mathrm{LDH}$ could be 
prepared. During characterisation (XRD, the combination of SEM images and SEM-EDX elemental maps of sodium polyacrylate, the pristine as well as the intercalated CaFe-LDH, IR spectroscopy), it was found that the polyacrylate ions entered the interlamellar space of the LDH, indeed. Measurements with dielectric relaxation spectroscopy on the flash-cooled and gradually warmed-up samples indicated a complex picture. It was found, in accordance with the previously mentioned multisided characterisation results, that large portions of the polymer ions were among the layers (the polymer largely lost its mobility observed without the LDH). However, some mobility was retained, indicating that parts of the polymer is on the outer surface, wrapping the LDH from the outside as well.

The results described and discussed in the dissertation contribute to a deeper understanding of the fine structural details of LDHs, especially their dehydration-rehydration behaviour, and help in devising functional nanocomposites, which may have diverse uses. 


\section{ACKNOWLEDGEMENT}

First of all, let me gratefully acknowledge the immense support and help of Drs István Pálinkó and Ákos Kukovecz. My grateful thanks go to them for their encouragement, their teaching I have received, and the vivid scientific discussions I could take part during the years I have spent in their unique research group.

Let me also gratefully acknowledge the efforts of Dr. Pál Sipos for his valuable insights and suggestions. I wish to express my sincere thanks to Dr. Mónika Ádok for her detailed review and excellent advices during the preparation of this thesis. Many thanks are to all members of the Department of Applied and Environmental Chemistry and the Material and Solution Structure Research Group as well.

I thank to all who helped me in any aspects in- and outside of the University of Szeged. Many thanks to my family and friends for the tremendous support they gave me in the last years. 


\section{MAGYAR NYELVÜ ÖSSZEFOGLALÓ (HUNGARIAN SUMMARY)}

A jelen értekezéshez vezető kísérleti munka során a hangsúlyt a hidrokalumit-típusú $\mathrm{CaFe}$ réteges kettős hidroxidok (layered double hydroxide - LDH) szerkezeti tulajdonságainak meghatározására fektettük. Legfőképpen a dehidratáció-rehidratáció folyamata, különösen az utóbbi, érdekelt bennünket egyrészt azért, mert ezt - legalábbis a rehidratációs részfolyamat lépéseit -, eddig nem nagyon vizsgálták, másrészt azért, mert a dehidratációs-rehidratációs technika az egyik fő módszer interkalált szerkezetek előállítására, melynek során különféle méretü és bonyolultságú anionok juttathatók be a réteges kettős hidroxid rétegközi terébe.

Igyekeztünk minél több információhoz jutni, ezért sokféle módszert alkalmaztunk, úgy mint egyszerű és összetett mikroszkópiás technikákat (TEM, SEM, SEM-EDX), termikus módszereket, FT-IR, ${ }^{57} \mathrm{Fe}$ Mössbauer és dielektromos relaxációs spektroszkópiákat, és mint az LDH-k legfőbb szerkezetvizsgálati módszerét, a röntgendiffraktometriát, annak mind statikus, mind időfüggő változatát. A különféle technikák által nyerhető eredmények leggyakrabban egymást kiegészítő természetűek voltak, így a jelenségek, amennyire lehet, teljes megértéséhez a mozaikokat gondosan (és gondolkodva) kellett egymáshoz illesztenünk.

A dolgozat első részében a dehidratált $\mathrm{CaFe}-\mathrm{LDH}$ rehidratációjának vizsgálata során nyert eredményeinket tárgyalom.

Hőkezelés hatására $773 \mathrm{~K}$-en a CaFe-LDH réteges szerkezete összeomlik. A szerkezeti átalakulás több lépésben ment végbe, melyeket a termogravimetria módszerével azonosítottuk és követtük. A tömegveszteségek különböző hőmérséklettartományokban mentek végbe, melyeket - összevetve az irodalomból vett eredményekkel - az LDH különféle pozícióiban elhelyezkedő vízmolekulákhoz, és a szerkezeti $\mathrm{OH}$-csoportokhoz rendeltük. A termikus viselkedés ismeretében úgy döntöttünk, hogy az előzőleg $773 \mathrm{~K}$ hőmérsékleten dehidratált és a réteges szerkezetüket már elvesztett minták részleges, illetve, nagyobb relatív páratartalomnál, teljes rehidratációját végezzük el. A rehidratációs lépések azonosítása és követése statikus és időfüggő röntgendiffraktometriával, dielektromos spektroszkópiával, FTIR és ${ }^{57} \mathrm{Fe}$ Mössbauer spektroszkópiával, valamint a részlegesen rehidratált minták termogravimetriás analízisével történt. Arra voltunk kíváncsiak, hogy az összeomlott szerkezetü kettős hidroxidok milyen mértékben képesek visszanyerni eredeti vagy ahhoz hasonló szerkezetüket a különféle páratartalmú közegekben.

A rehidratáció során három különböző egymást követő, de egymástól élesen nem elhatárolható lépést különítettünk el. Azt találtuk, hogy az emelkedő páratartalommal a 
szerkezet visszaalakulásának a mértéke is nőtt. Először az LDH vázszerkezete épült újra, és ezzel átfedő folyamatként megfigyeltük a rétegközi víz újbóli megjelenését is. A réteges szerkezet teljes kiépülése elött már a fiziszorbeált víz is azonosítható volt. Összességében elmondható, hogy háromféle vízmolekulát különböztethettünk meg, amelyek kötődési erősségük növekvő sorrendjében, az anyag külső felületén, a rétegközi térben illetve a rétegekben $\mathrm{OH}$-csoportokként kötve helyezkednek el.

A szerkezetvizsgálathoz leggyakrabban használt röntgendiffraktometrián, termogravimetrián, FT-IR spektroszkópián kívül, a dielektromos relaxációs spektroszkópiai módszer nyújtott nagy segítséget a szerkezet-újraépülési folyamatok és az MWS határfelületi polarizáció azonosításában is (utóbbi egy zavaró hatásnak tekinthető a szerkezet rekonstrukciója során). A technikát a legeredményesebben úgy tudtuk használni, ha a részlegesen hidratált mintáinkat hirtelen lehütöttük, így a kontrollált páratartalmú közegben részlegesen rehidratált minták spektrumai direkt információt szolgáltattak a vízmolekulák pozíciójáról. A méréseket mély hőmérsékleteken kezdtük, szabályoztuk a minta felmelegedését, így az olyan típusú vízmolekulák relaxációi is megfigyelhetőek voltak, melyek szobahőmérsékleten csak az általunk már nem elérhető, magasabb frekvenciatartományban jelennek meg (azaz készülékünk mérési tartományát mintegy kiterjesztettük). A relaxációs idők hőmérsékletfüggéséből kiszámoltuk az egyes rehidratációs lépések aktiválási energiáit.

A szinkrotronalapú, időfüggő röntgendiffrakciós mérések szerint a részlegesen dehidratált (a hőkezelés hőmérsékletét úgy választottuk meg, hogy csak a fiziszorbeált és a rétegközi víz távozzék a rendszerből, azaz a rétegek ne dehidratálódjanak) CaFe-LDH minták vizes etanol átáramoltatásakor egy lépésben rehidratálódtak, míg az ugyanúgy dehidratált MgAl-LDH-minták esetén folyamatos rehidratációt figyeltünk meg.

${ }^{57} \mathrm{Fe}$ Mössbauer spektroszkópia alkalmazásával szerkezeti információk nyerhetők a CaFe-LDH mintában, illetve a hőkezelés során belőle származtatható anyagokban lévő Fe(III)-ionok közvetlen környezetéről. Ezt használtuk ki a különböző hőmérsékleten végzett hőkezelések során kialakult fázisok szerkezetének tanulmányozásakor. Bár e fázisok vizsgálata nem szerepelt az eredeti célkitűzések között, a Mössbauer spektroszkópiai és röntgendiffraktometriás mérési eredmények összevetésével sok, eddig nem ismert szerkezeti információhoz jutottunk.

$\mathrm{Az}$ LDH rétegein belül viszonylag egyszerüen cserélhetőek a töltéskompenzáló anionok, így az LDH-alapú nanokompozitok előállításának legegyszerúbb módja a rétegközi ionok cseréje. Kísérleti munkánk során megkíséreltük (többfalú) szén nanocső-CaFe-LDH 
kompozit előállítását azt remélve, hogy alkalmazási szempontból ígéretes anyaghoz jutunk (már maguk a csupasz nanocsövek is sokféle alkalmazási lehetöséggel kecsegtettek, és bár a várakozás izgalma sokat csillapodott az idők során, a nanocső-alapú kompozitoktól még ma is sokféle alkalmazást várnak). Ez a szintézis igazi kihívást jelentett, hiszen a vendég szén nanocső egy töltés nélküli apoláris anyag (még akkor is, ha a szintézis során az anyag felületén jelentős mennyiségü hibahely keletkezik), míg a gazda LDH poláris, és a rétegek pozitív töltésủek. Először, az eddigi vizsgálatainkhoz illeszkedő dehidratációs-rehidratációs módszert próbáltuk ki. Ez azonban még akkor sem müködött, amikor a szén nanocső felületét oxidatív kezeléssel funkcionalizáltuk, sőt még akkor sem, ha anionos felületaktív molekulát alkalmazva a szén nanocsövet becsomagoltuk úgy, hogy a tenzides "csomag" anionos része kerülhetett kölcsönhatásba az LDH-val. A legjobb esetben is csak azt tapasztaltuk, hogy olyan kompozitunk lett, amelyben egy vékony LDH réteg borította a szén nancsövet. Végülis a rétegezés (layer-by-layer) technikája eredményre vezetett. Ennek során az LDH rétegszerkezetét megbontottuk (delamináltuk), és egy gondosan zsírtalanított kvarc üveglapra rétegenként vittük fel a delaminált réteges kettős hidroxidot és a szén nanocsövet.

A dehidratációs-rehidratációs interkalációs techanika azonban müködött a poliakriláttartalmú CaFe-LDH kompozit előállítása során. A kompozit szerkezetének műszeres (XRD, SEM, SEM-EDX, IR spektroszkópia) jellemzésével bizonyítottuk, hogy a poliakrilát-ionokat sikerült interkalálni az LDH rétegei közé. A hirtelen lehütött majd szabályozott módon szobahőmérsékletig felmelegedni engedett mintákon végzett dielektromos mérések lehetővé tették egy komplex szerkezeti modell felállítását. Ezek a mérések, az előbb felsorolt müszeres módszerek eredményeivel összhangban, azt jelezték, hogy a poliakrilát-ion nagy része az LDH rétegei között helyezkedik el - a nem interkalált polimerhez képest nagymértékü mobilitáscsökkenést tapasztaltunk. Ugyanakkor az, hogy a polimerionnak még maradt némi mobilitása, azt mutatja, hogy a polimerion egy része nem a rétegek között van, hanem "kilóg" a rétegek közül, és mintegy körülöleli az LDH-t.

$\mathrm{Az}$ értekezésben leírt és részletesen tárgyalt eredmények hozzájárulnak a réteges kettős hidroxidok finomszerkezetének megértéséhez, valamint segítséget nyújtanak új funkcionális nanokompozitok tervezéséhez, amelyek különféle felhasználási lehetőségekkel kecsegtetnek. 


\section{References}

[1] X. Duan, Evans, D.G., Layered Double Hydroxides, in: D.M.P. Mingos, (Ed.), Struct. Bonding, Springer, Berlin, Germany, (2006), 1-87.

[2] W.H.F. Taylor, Mineral. Mag. 36 (1969) 465-479.

[3] W.H.F. Taylor, Mineral. Mag 39 (1973) 377-389.

[4] S.J. Mills, A.G. Christy, J.M.R. Génin, T. Kameda, F. Colombo, Mineral. Mag. 76 (2012) 1289-1336.

[5] C. Hochstetter, J. Prakt. Chem 27 (1842) 375-378.

[6] G. Brown, M.C. Gastuche, Clay Miner. 7 (1967) 193-201.

[7] I. Rousselot, C. Taviot-Guého, F. Leroux, P. Léone, P. Palvadeau, J.-P. Besse, J. Solid State Chem. 167 (2002) 137-144.

[8] L. Vieille, E.M. Moujahid, C. Taviot-Guého, J. Cellier, J.-P. Besse, F. Leroux, J. Phys. Chem. Solids 65 (2004) 385-393.

[9] T.-H. Kim, I. Heo, S.-M. Paek, C.-B. Park, A.-J. Choi, S.-H. Lee, J.-H. Choy, J.-M. Oh, Bull. Korean Chem. Soc. 33 (2012) 1845-1850.

[10] J. Tronto, A. C. Bordonal, Z. Naal, J.B. Valim, Conducting Polymers / Layered Double Hydroxides Intercalated Nanocomposites, in: Y. Mastai, (Ed.), Materials Science - Advanced Topics, InTech, (2013), 1-30.

[11] de Roy A, Forano C, J.-P. Besse, Synthesis and Post-Synthesis Modification, in: V. Rives, (Ed.), Layered Double Hydroxides: Present and Future, Nova Science Publisher, Inc, New York, (2001), 1-41.

[12] D. Srankó, M. Sipiczki, É.G. Bajnóczi, M. Darányi, Á. Kukovecz, Z. Kónya, S.E. Canton, K. Norén, P. Sipos, I. Pálinkó, J. Mol. Struct. 993 (2011) 62-66.

[13] S. Miyata, Clays Clay Miner. 28 (1980) 50-56.

[14] M. Bellotto, B. Rebours, O. Clause, J. Lynch, J. Phys. Chem. 100 (1996) 8527-8534.

[15] A.M. Fogg, J.S. Dunn, S.G. Shyu, D.R. Cary, D. O'Hare, Chem. Mater. 10 (1998) 351-355.

[16] J.M. Fernandez, M.A. Ulibarri, F.M. Labojos, V. Rives, J. Mater. Chem. 8 (1998) 2507-2514.

[17] A. S. Bookin, V.A. Drits, Clays Clay Miner. 41 (1993) 551-557.

[18] A. S. Bookin, V.A. Drits, V.I. Cherkashin, Clays Clay Miner. 41 (1993) 558-564.

[19] A.I. Khan, D. O'Hare, J. Mater. Chem. 12 (2002) 3191-3198.

[20] M.R. Berber, I.H. Hafez, K. Mingawa, T. Mori, T. M., Versatile Nanocomposite Formulation System of Non-Steroidal Anti-Inflammatory Drugs of the Arylalkanoic Acids, in: D.A. Hashim, (Ed.), Advances in Nanocomposite Technology, (2011), 335360.

[21] S.P. Newman, W. Jones, New J. Chem. 22 (1998) 105-115.

[22] L. Pesic, S. Salipurovic, V. Markovic, D. Vucelic, W. Kagunya, W. Jones, J. Mater. Chem. 2 (1992) 1069.

[23] W. Hofmeister, H.V. Platen, Crystallography Reviews 3 (1992) 3-26.

[24] A.V. Besserguenev, A.M. Fogg, R.J. Francis, S.J. Price, D. O'Hare, Chem. Mater. 9 (1997) 241-247.

[25] V.R. Constantino, R.L. Vera, T.J. Pinnavaia, Inorg. Chem. 34 (1995) 886-892.

[26] S.K. Yun, V.R. Constantino, T.J. Pinnavaia, Clays Clay Miner. 43 (1995) 503-510.

[27] M.A. Drezdzon, Inorg. Chem. 27 (1988) 4628-4632.

[28] K. Chibwe, W. Jones, J. Chem. Soc., Chem. Commun. (1989) 926-927.

[29] A.A.A. Ahmed, Z.A. Talib, M.Z. bin Hussein, A. Zakaria, J. Solid State Chem. 191 (2012) 271-278. 
[30] D.X. Gouveia, O.P. Ferreira, A.G. Souza Filho, M.G.d. Silva, J.A.C. Paiva, O.L. Alves, J.M. Filho, J. Mater. Sci. 42 (2006) 534-538.

[31] M. Intissar, J.-C. Jumas, J.-P. Besse, F. Leroux, Chem. Mater. 15 (2003) 4625-4632.

[32] F. Cavani, F. Trifiró, A. Vaccari, Catal. Today 11 (1991) 173-301.

[33] F. Wong, R.G. Buchheit, Prog. Org. Coat. 51 (2004) 91-102.

[34] J. Rocha, M. del Arco, V. Rives, M.A. Ulibarri, J. Mater. Chem. 9 (1999) 2499-2503.

[35] V. Vágvölgyi, S.J. Palmer, J. Kristóf, R.L. Frost, E. Horváth, J. Colloid Interface Sci. 318 (2008) 302-308.

[36] R.L. Frost, S.J. Palmer, F. Theiss, J. Raman Spectrosc. 42 (2011) 1163-1167.

[37] J.S. Valente, G. Rodriguez-Gattorno, M. Valle-Orta, E. Torres-Garcia, Mater. Chem. Phys. 133 (2012) 621-629.

[38] N. Ukrainczyk, T. Matusinovic, S. Kurajica, B. Zimmermann, J. Sipusic, Thermochim. Acta 464 (2007) 7-15.

[39] A. Vaccari, Appl. Clay Sci. 14 (1999) 161-198.

[40] S. Aisawa, H. Hirahara, K. Ishiyama, W. Ogasawara, Y. Umetsu, E. Narita, J. Solid State Chem. 174 (2003) 342-348.

[41] Y. You, H. Zhao, G.F. Vance, J. Mater. Chem. 12 (2002) 907-912.

[42] H. Nakayama, N. Wada, M. Tsuhako, Int. J. Pharm. 269 (2004) 469-478.

[43] S. Miyata, Clays Clay Miner. 31 (1983) 305-311.

[44] C. Forano, T. Hibino, F. Leroux, C. Taviot-Guého, Layered Double Hydroxides, in: F. Bergaya, B.K.G. Theng, G. Lagaly, (Eds.), Handbook of Clay Science, Elsevier Ltd, (2006), 1021-1095.

[45] A.J. Marchi, C.R. Apesteguía, Appl. Clay Sci. 13 (1998) 35-48.

[46] H. Pfeiffer, E. Lima, V. Lara, J.S. Valente, Langmuir 26 (2010) 4074-4079.

[47] H. Pfeiffer, L. Martinez-dlCruz, E. Lima, J. Flores, M.A. Vera, J.S. Valente, J. Phys. Chem. C 114 (2010) 8485-8492.

[48] J.S. Valente, H. Pfeiffer, E. Lima, J. Prince, J. Flores, J. Catal. 279 (2011) 196-204.

[49] W. Feitknecht, Helv. Chim. Acta 25 (1942) 13-137.

[50] J.J. Bravo-Suarez, E.A. Páez-Mozo, S.T. Oyama, Quim. Nova 27 (2004) 601-614.

[51] J. He, M. Wei, B. Li, Y. Kang, D. Evans, X. Duan, Preparation of Layered Double Hydroxides, in: X. Duan, D. Evans, (Eds.), Layered Double Hydroxides, Springer, Berlin Heidelberg, (2006), 89-119.

[52] Y. Li, H. Li, M. Yang, X. He, P. Ni, L. Kang, Z.-H. Liu, Appl. Clay Sci. 52 (2011) 5155.

[53] M. Meyn, Beneke, K., Lagaly, G., Inorg. Chem. 29 (1990) 5201-5207.

[54] Y. Zhao, F. Li, R. Zhang, D.G. Evans, X. Duan, Chem. Mater. 14 (2002) 4286-4291.

[55] B.A. Fetter G, Lara VH, Bosch P, J Porous Mater. (2001) 8-227.

[56] N.Y. Seida Y, Nakamura Y, Clays Clay Miner. (2002) 50-525.

[57] V.R. Khusnutdinov, V.P. Isupov, ChemSusDev 15 (2007) 367-372.

[58] F. Leroux, J.-P. Besse, Layered double hydroxide / polymer nanocomposites, in: W. Fernando, S. Kestur Gundappa, (Eds.), Interface Science and Technology, Elsevier, (2004), 459-495.

[59] F. Leroux, C. Taviot-Gueho, J. Am. Chem. Soc. 15 (2005) 3628-3642.

[60] J. Pisson, C. Taviot-Gueho, Y. Israëli, F. Leroux, P. Munsch, J.-P. Itie, V. Briois, N. Morel-Desrosiers, J.-P. Besse, J. Phys. Chem. B 107 (2003) 9243-9248.

[61] F. Leroux, P. Aranda, J.-P. Besse, E. Ruiz-Hitzky, Eur. J. Inorg. Chem. (2003) 12421251.

[62] I.C. Villegas, O.H. Giraldo, K. Laubernds, S.L. Suib, Inorg. Chem. 42 (2003) 56215631.

[63] F. Malherbe, J.-P. Besse, J. Solid State Chem. 155 (2000) 332-341. 
[64] J.B. Qiu, G. Villemure, J. Electroanal. Chem. 395 (1995) 159-166.

[65] F.C. Prevot V, Besse JP, Inorg. Chem. 37 (1998) 4293-4301.

[66] L. Li, R. Ma, Y. Ebina, N. Iyi, T. Sasaki, Chem. Mater. 17 (2005) 4386-4391.

[67] M. Sipiczki, P. Sipos, I. Pálinkó, Syntheses, Characterisation and Applications of genuine Layered Double Hydroxide Thin Films, in: C.A.G. DA, (Ed.), Hydroxides: Synthesis, Types and Applications, Nova Science Publishers Inc, New York, (2012), 221-239.

[68] S. Srivastava, N.A. Kotov, Acc. Chem. Res. 41 (2008) 1831-1841.

[69] N.A. Kotov, T. Haraszti, L. Turi, G. Zavala, R.E. Geer, I. Dekany, J.H. Fendler, J. Am. Chem. Soc. 119 (1997) 6821-6832.

[70] C. Ziegler, S. Werner, M. Bugnet, M. Worsching, V. Duppel, G.A. Botton, C. Scheu, B.V. Lotsch, Chem. Mater. 25 (2013) 4892-4900.

[71] M. Adachi-Pagano, C. Forano, J.-P. Besse, Chem. Commun. (2000) 91-92.

[72] F. Leroux, M. Adachi-Pagano, M. Intissar, S. Chauvière, C. Forano, J.-P. Besse, J. Mater. Chem. 11 (2001) 105-112.

[73] T. Hibino, W. Jones, J. Mater. Chem. 11 (2001) 1321-1323.

[74] K.K. Rao, M. Gravelle, J.S. Valente, F. Figueras, J. Catal. 173 (1998) 115-121.

[75] F. Li, X. Duan, Applications of Layered Double Hydroxides, Struct. Bonding, Springer-Verlag, (2006), 193-223.

[76] C. Taviot-Guého, F. Leroux, In Situ Polymerization and Intercalation of Polymers in Layered Double Hydroxides, (2006), 121-159.

[77] J.K. Choy, S.Y; Jeong, Y.-J.; Park J.-S., Angew. Chem. Int. Ed. Engl. 39 (2000) 40414045.

[78] S. Albertazzi, F. Basile, P. Benito, P. Delgallo, G. Fornasari, D. Gary, V. Rosetti, A. Vaccari, Catal. Today 128 (2007) 258-263.

[79] H.B. Yao, H.Y. Fang, Z.H. Tan, L.H. Wu, S.H. Yu, Angew. Chem. Int. Ed. Engl. 49 (2010) 2140-2145.

[80] F. Leroux, J.-P. Besse, Chem. Mater. 13 (2001) 3507-3515.

[81] K.A. Page, K. Adachi, Polymer 47 (2006) 6406-6413.

[82] M.-Q.Z. Zhao, Qiang; Huamg, Jia-Qi; Wei Fei, Adv. Funct. Mater. 22 (2012) 675-694.

[83] L. Liu, J.C. Grunlan, Adv. Funct. Mater. 17 (2007) 2343-2348.

[84] L. Wang, X. Xie, S. Su, J. Feng, C.A. Wilkie, Polym. Degrad. Stab. 95 (2010) 572578.

[85] H. Li, G. Zhu, Z.-H. Liu, Z. Yang, Z. Wang, Carbon 48 (2010) 4391-4396.

[86] S. Huang, H. Peng, W.W. Tjiu, Z. Yang, H. Zhu, T. Tang, T. Liu, J. Phys. Chem. B 114 (2010) 16766-16772.

[87] M.-Q. Zhao, Q. Zhang, X.-L. Jia, J.-Q. Huang, Y.-H. Zhang, F. Wei, Adv. Funct. Mater. 20 (2010) 677-685.

[88] M. Endo, M.S. Strano, P.M. Ajayan, Carbon Nanotubes 111 (2008) 13-61.

[89] H. Wang, X. Xiang, F. Li, J. Mater. Chem. 20 (2010) 3944-3952.

[90] M.M. Shaijumon, N. Bejoy, S. Ramaprabhu, Appl. Surf. Sci. 242 (2005) 192-198.

[91] B. Pradhan, S.K. Srivastava, Composites Part A: Applied Science and Manufacturing 56 (2014) 290-299.

[92] B. Yang, Z. Yang, R. Wang, T. Wang, Electrochim. Acta 111 (2013) 581-587.

[93] R. Schöllhorn, Chem. Mater. 8 (1996) 1747-1757.

[94] C.O. Oriakhi, I.V. Farr, M.M. Lerner, J. Mater. Chem. 6 (1996) 103-107.

[95] C. Vaysse, L. Guerlou-Demourgues, C. Delmas, E. Duguet, Macromol. 37 (2004) 4551.

[96] P. Sipos, P.M. May, G. Hefter, Analyst 125 (2000) 955-958.

[97] P. Sipos, G. Hefter, P.M. May, J. Chem. Eng. Data 45 (2000) 613-617. 
[98] Y. Seida, Y. Nakano, Water Res. 34 (2000) 1487-1494.

[99] D.R. Lide, CRC Handbook of Chemistry and Physics, 85th Edition, Taylor \& Francis, (2004).

[100] Z. Liu, R. Ma, Y. Ebina, K. Takada, T. Sasaki, Chem. Mater. 19 (2007) 6504-6512.

[101] Z. Klencsár, MossWin 4.0 Pre, A Software for Mösbauer Spectrum Analysis, Budapest, Hungary.

[102] S.A. Kremer F, Broadband Dielectric Spectroscopy, Springer-Verlag, Berlin, Heidelberg, New York, (2003).

[103] Alpha-A High Resolution Dielectric, Conductivity, Impedance and Gain Phase Modular Measurement System User's Manual, Novocontrol Technologies Gmbh \& Co. KG, (2005).

[104] WinDETA 5.56 Owner's Manual, Novocontrol Technologies Gmbh \& Co. KG, (2006).

[105] M. Nilsson, G. Alderborn, M. Stromme, Chem. Phys. 295 (2003) 159-165.

[106] M. Nilsson, G. Frenning, J. Grasjo, G. Alderborn, M. Stromme, J. Phys. Chem. B 110 (2006) 20502-20506.

[107] Liquid Cylindrical Sample Cell USER's Manual, Novocontrol Technologies Gmbh \& Co. KG, (2007).

[108] M. Sipiczki, D.F. Srankó, Á. Kukovecz, Z. Kónya, P. Sipos, I. Pálinkó, Chem. Pap. 65 (2011) 840-846.

[109] M. Sipiczki, E. Kuzmann, Z. Homonnay, J. Megyeri, I. Pálinkó, P. Sipos, J. Mol. Struct. 1044 (2013) 116-120.

[110] S. Morlat-Thérias, C. Mousty, P. Palvadeau, R. Molinié, P. Léone, J. Rouxel, C. Taviot-Gueho, A. Ennaqui, A. de Roy, J.-P. Besse, J. Solid State Chem. 144 (1999) 143-151.

[111] T.-H. Kim, H.J. Kim, J.-M. Oh, J. Nanomater. 2012 (2012) 1-7.

[112] G. Hu, D. O'Hare, J. Am. Chem. Soc. 127 (2005) 17806-17813.

[113] P. Tarte, Nature 207 (1965) 973-974.

[114] P.S. Randhawa, K. Gandotra, Indian J. Pure Appl. Phys. 45 (2007) 795-799.

[115] Y. Hayashi, Y. E. Ryabov, A. Gutina, Y. Feldman, American Institute of Physics (2004).

[116] A. Samariya, S.N. Dolia, A.S. Prasad, P.K. Sharma, S.P. Pareek, M.S. Dhawan, S. Kumar, Curr Appl Phys 13 (2013) 830-835.

[117] H. Maluszýnska, P. Czarnecki, Z. Kristallogr. 221 (2006) 218-225.

[118] D.-Y. Wang, A. Leuteritz, Y.-Z. Wang, U. Wagenknecht, G. Heinrich, Polym. Degrad. Stab. 95 (2010) 2474-2480.

[119] L. Wang, X. Xu, D.G. Evans, X. Duan, D. Li, J. Solid State Chem. 183 (2010) 11141119.

[120] S.Negami. Havriliak, S, J. Polym. Sci. C 14 (1966) 99-117.

[121] S.Negami. S. Havriliak, Polymer 8 (1967) 161-205.

[122] K.S.R.H.Cole. Cole, R. H. , J. Chem. Phys. 9 (1941) 341-351.

[123] N. Ito, R. Richert, J. Chem. Phys. 123 (2005) 106101.

[124] J. Sjostrom, J. Swenson, R. Bergman, S. Kittaka, J. Chem. Phys. 128 (2008) 154503.

[125] D.H. R.A. Pethrick, K. Jeffrey, S. Affrossman, J. Mater. Sci. 31 (1996) 2623-2629.

[126] P.A.M. Steeman, F.H.J. Maurer, M.A. Vanes, Polymer 32 (1991) 523-530.

[127] K. Asami, Prog. Polym. Sci. 27 (2002) 1617-1659.

[128] J.S. R. Bergman, Nature 403 (2000) 283-286.

[129] J. Pérez-Ramirez, Abelló, S., van der Pers, N.M., J. Phys Chem. C (2007) 3642-3650.

[130] L. Frunza, H. Kosslick, S. Frunza, A. Schonhals, J. Phys. Chem. B 106 (2002) 91919194. 
[131] L. Frunza, A. Schonhals, S. Frunza, V.I. Parvulescu, B. Cojocaru, D. Carriazo, C. Martin, V. Rives, J. Phys. Chem. A 111 (2007) 5166-5175.

[132] M. Carsi, M.J. Sanchis, R. Diaz-Calleja, E. Riande, M.J.D. Nugent, Macromol. 45 (2012) 3571-3580.

[133] P.J. Purohit, J.s.E. Huacuja-Sánchez, D.-Y. Wang, F. Emmerling, A. Thünemann, G. Heinrich, A. Schönhals, Macromol. 44 (2011) 4342-4354.

[134] A. Schönhals, H. Goering, F.R. Costa, U. Wagenknecht, G. Heinrich, Macromol. 42 (2009) 4165-4174.

[135] M. Laurati, P. Sotta, D.R. Long, L.A. Fillot, A. Arbe, A. Alegrìa, J.P. Embs, T. Unruh, G.J. Schneider, J. Colmenero, Macromol. 45 (2012) 1676-1687. 